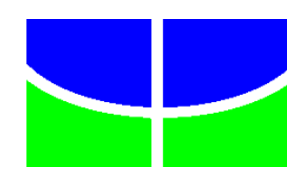

Universidade de Brasília - UnB

Departamento de Economia

Mestrado Profissional em Regulação e Gestão de Negócios - REGEN

\title{
AS SANÇÕES ADMINISTRATIVAS APLICADAS PELA AGÊNCIA NACIONAL DE ENERGIA ELÉTRICA - ANEEL - UM ESTUDO SOBRE A REGULAMENTAÇÃO E AS PRÁTICAS DA AGÊNCIA
}

\section{EDUARDO ROSSI FERNANDES}

Brasília, dezembro de 2013 


\section{FICHA CATALOGRÁFICA}

\section{FERNANDES, Eduardo Rossi}

As Sanções Administrativas Aplicadas pela Agência Nacional de Energia Elétrica ANEEL - Um Estudo sobre a Regulamentação e as Práticas da Agência, 2013. 106pp.

Dissertação: Mestrado Profissional em Regulação e Gestão de Negócios

Orientador: Prof. Dr. Bernardo Mueller

1. Regulação e Fiscalização de Serviços Públicos

2. Imposição de Sanções Administrativas no Setor Elétrico

3. Discricionariedade e Segurança Jurídica

I. CERME/UnB

II. Título: Mestre

\section{Cessão de Direitos}

NOME DO AUTOR: Eduardo Rossi Fernandes

TÍTULO DA DISSERTAÇÃO DE MESTRADO PROFISSIONAL: As Sanções Administrativas Aplicadas pela Agência Nacional de Energia Elétrica - ANEEL - Um Estudo sobre a Regulamentação e as Práticas da Agência.

GRAU/ANO: Mestre/2013

É concedida à Universidade de Brasília permissão para reproduzir cópias desta dissertação de mestrado profissional e para emprestar ou vender tais cópias somente para propósitos acadêmicos ou científicos. $\mathrm{O}$ autor reserva direitos de publicação e nenhuma parte desta dissertação de mestrado pode ser reproduzida sem autorização por escrito do autor. 


\title{
Eduardo Rossi Fernandes
}

\section{AS SANÇÕES ADMINISTRATIVAS APLICADAS PELA AGÊNCIA NACIONAL DE ENERGIA ELÉTRICA - ANEEL - UM ESTUDO SOBRE A REGULAMENTAÇÃO E AS PRÁTICAS DA AGÊNCIA}

\author{
Dissertação apresentada ao Departamento de Economia \\ da Universidade de Brasília para obtenção do Título de \\ Mestre em Regulação e Gestão de Negócios. \\ Comissão Examinadora formada pelos membros:
}
Prof. Dr. Bernardo Pinheiro Machado Mueller - UnB (Presidente e Orientador)

\section{Prof. Dr. Paulo César Coutinho - UnB (Membro Titular)}

\section{Dr. Edvaldo Alves de Santana - ANEEL (Membro Titular)}

Local: Universidade de Brasília

Departamento de Economia

$$
\text { UnB - Brasília }
$$

Dezembro de 2013 
Aos meus pais, Negrito e Nélide, por terem me ensinado quase tudo de que precisei neste trabalho. À minha esposa, Camilla, pelo incentivo, pelo apoio e pela compreensão durante sua elaboração. 


\section{AGRADECIMENTOS}

Agradeço à UnB, por ofertar um curso de alta qualidade como o REGEN, e agradeço à ANEEL por proporcionar que eu o cursasse. Tudo o que eu realizei ou venha a realizar com o que lá aprendi, inclusive esta dissertação, não seria possível sem o investimento dessas instituições públicas na formação de servidores qualificados. Não tenho dúvidas de que esse tipo de investimento é bastante vantajoso para a Administração Pública e, portanto, para o país.

Agradeço ao Professor Bernardo, por todo o apoio e orientação, principalmente na fase de definição do escopo de meu projeto, e aos Professores Paulo e Edvaldo, por suas contribuições, sem as quais este trabalho com certeza seria bem menos relevante.

Sou grato também aos colegas de curso e demais professores, assim como aos colegas de trabalho da ANEEL, pelas ótimas discussões técnicas que tivemos, e que muito inspiraram e contribuíram com meu projeto.

Por fim, agradeço à minha esposa Camilla, por ter estado ao meu lado, em todos os sentidos, durante todo o curso e toda a confecção deste trabalho. 


\section{RESUMO}

O setor elétrico brasileiro é um complexo ambiente econômico, cuja regulação é de responsabilidade da Agência Nacional de Energia Elétrica - ANEEL.

Um aspecto fundamental da regulação consiste no exercício das funções de regulamentação (definir as regras) e fiscalização (verificar seu cumprimento). A efetividade desta última pressupõe a possibilidade de aplicação de sanções às empresas que cometem infrações regulamentares.

As sanções administrativas são um poderoso instrumento por meio do qual a Agência Reguladora reprime as empresas infratoras e previne o cometimento de infrações pelas demais. O processo de imposição de sanções é bastante complexo, e a principal componente dessa complexidade é a discricionariedade inerente à atividade.

A atividade sancionadora da ANEEL é o objeto deste estudo, que é formado por uma análise crítica da Resolução Normativa $n^{\circ}$ 63, de 12 de maio de 2004, por meio da qual a Agência regulamentou o processo de aplicação de sanções, bem como de sua aplicação.

São apresentados e explorados os contextos histórico e legal, bem como o cenário atual, no que diz respeito ao mercado regulado, à ANEEL e à regulamentação. É traçado também um perfil da função sancionadora da Agência, ao longo de seus mais de 15 anos de atividade.

As considerações são feitas à luz de conceitos do direito administrativo sancionador e da regulação econômica.

As sugestões de aprimoramento da norma apresentadas são baseadas na simplificação do processo, em sua objetividade e, principalmente, no uso comedido da discricionariedade do regulador, com o objetivo de garantir a segurança jurídica no setor elétrico.

Palavras-chave: 1.Regulação. 2.Fiscalização. 3.Sanção Administrativa. 4.Discricionariedade. 5.Segurança Jurídica. 6.Resolução Normativa ANEEL nº 63/2004. 7.Setor Elétrico Brasileiro. 


\section{ABSTRACT}

The Brazilian electric power market is a complex economic environment, in which regulation is responsibility of the National Electric Energy Agency, ANEEL.

A key aspect of regulation consists in the exercise of setting rules and supervising the agents involved, to check compliance to those rules. The effectiveness of the supervision function depends on the possibility of imposing sanctions on companies who commit regulatory infractions.

Administrative sanctions are a powerful means by which the Regulatory Agency represses transgressing companies and prevents transgressions by other companies. The process of imposing sanctions is quite complex, and the main component of this complexity is the discretion that is inherent to the process.

ANEEL's sanctioning practices are the object of this study, which is composed of a critical analysis of the Resolution $n^{\circ}$ 63/2004, through which the Agency regulated the process of penalty enforcement, and how it is applied.

The historical and legal context is presented and explored, as well as the current scenario, regarding the regulated market, ANEEL's structure and the relevant regulation. A description of the sanctioning profile of the Agency over its more than 15 years of activity is also presented.

The considerations are based on concepts of sanctioning administrative law and economic regulation.

Suggestions for improvement of Regulation $n^{\circ}$ 63/2004 are made based on the simplification of the process, in its objectivity and especially in moderating the use of the regulator's discretion, in order to ensure legal certainty in the electric energy market.

Keywords: 1.Regulation. 2.Supervision. 3.Administrative Sanction. 4.Discretion. 5.Legal Certainty. 6.ANEEL Resolution REN nº 63/2004. 7.Brazilian Electric Power Market. 


\section{LISTA DE FIGURAS}

Figura 2.1 - Estrutura institucional do setor elétrico 18

Figura 2.2 - Principais atividades na cadeia de produção de energia elétrica 19

Figura 2.3 - Destaques da legislação no processo de imposição de penalidades pela ANEEL 24 Figura 5.1 - Atuação das Superintendências de Fiscalização da ANEEL ............................ 40 Figura 5.2 - Diretoria Colegiada e processos organizacionais na ANEEL ............................ 41

Figura 5.3 - Mapa da descentralização de atividades da ANEEL ....................................... 43

Figura 6.1 - Os grupos de multas previstos na REN n ${ }^{\circ}$ 63/2004 ...................................... 48

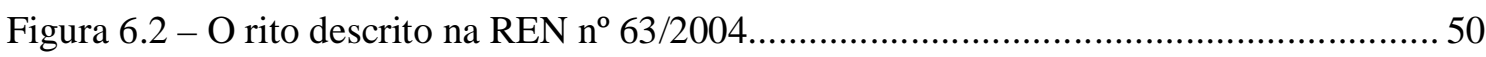

Figura 8.1 - Quantidade de autos de infração lavrados por ano......................................... 64

Figura 8.2 - Valores iniciais e finais dos autos de infração lavrados (R \$ milhões) ................ 65

Figura 8.3 - Recursos administrativos, ações judiciais, autos de infração pagos e celebração

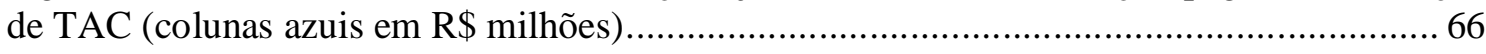

Figura 8.4 - Comparação entre as decisões da Superintendência (ou Agência Estadual) e da

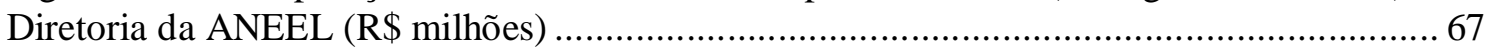

Figura 8.5 - Quantidade de autos emitidos (conforme última decisão administrativa) e de

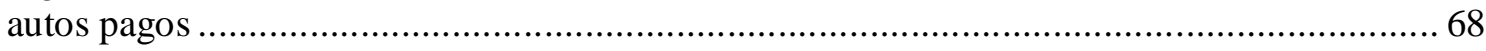

Figura 8.6 - Valores das multas emitidas (conforme última decisão administrativa) e

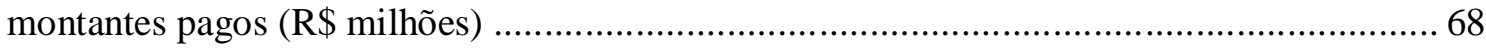

Figura 8.7 - Valores e quantidades de multas por ramo de atividade, conforme última decisão

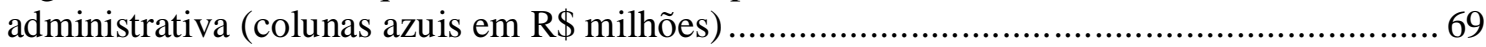

Figura 8.8 - Valores e quantidades de multas por Superintendência ou Agência Estadual, conforme última decisão administrativa (barras azuis em $\mathrm{R} \$$ milhões) …........................... 71

Figura 8.9 - Valores e quantidades de multas para as 40 empresas mais multadas (barras azuis

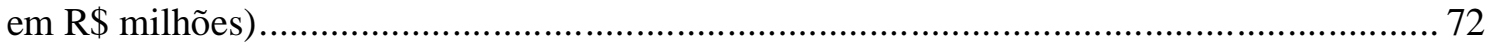

Figura 8.10 - As 40 empresas mais multadas, em termos da relação do valor das multas sobre

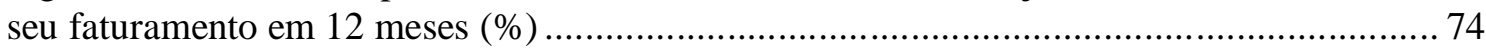

Figura 8.11 - Relação entre o valor das multas e o faturamento das empresas, por ano......... 75 Figura 9.1 - Relação entre critérios para definição de valores de multas (Decreto $\mathrm{n}^{\circ}$

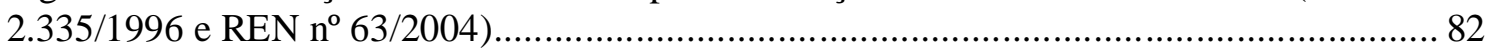

Figura 10.1 - Valores máximos das multas por grupo (\% do faturamento anual da empresa

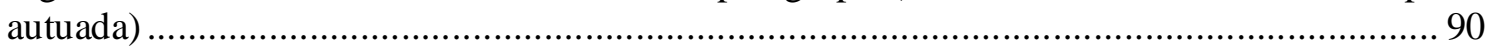

Figura 10.2 - Valor máximo da multa dividido em parcelas que são definidas pela

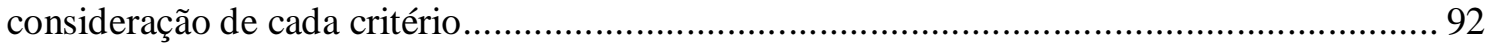

Figura 10.3 - Exemplo de multa estabelecida por parcelas correspondentes aos critérios...... 93

Figura 10.4 - Proposta para composição do valor das multas aplicadas pela ANEEL ........... 94 
Figura 10.5 - Visão geral do processo de fiscalização ....................................................... 96

Figura 10.6 - Comparação entre a regulamentação vigente e a proposta............................. 98 


\section{LISTA DE TABELAS}

Tabela 5.1 - Agências Reguladoras Estaduais.

43

Tabela 5.2 - Descentralização de atividades em cada Superintendência de Fiscalização da

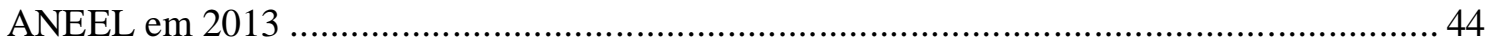

Tabela 6.1 - Infrações tipificadas na REN 63/2004 …................................................. 47

Tabela 6.2 - Grupos de penalidades na REN no 63/2004 ........................................... 48

Tabela 7.1 - Critério da SFE para sanções irrecorríveis ..................................................... 53

Tabela 7.2 - Critério da SFF para inadimplência em envio de informações ......................... 54

Tabela 7.3 - Critério da SFF para inconsistência em envio de informações ......................... 55

Tabela 7.4 - Critério da SFF para irregularidade no AIS e na BRR ................................... 56

Tabela 7.5 - Critério da SFF para sanções irrecorríveis (irregularidade no AIS e na BRR) ... 56

Tabela 7.4 - Critério da SFG para gravidade (usinas em obras)........................................ 58

Tabela 7.5 - Critério da SFG para gravidade (usinas em operação) ..................................... 59

Tabela 7.6 - Critério da SFG para danos (usinas em obras).............................................. 59

Tabela 7.7 - Critério da SFG para danos (usinas em operação) ......................................... 59

Tabela 9.1 - Subjetividade no exercício da discricionariedade específica ............................ 86 


\section{SUMÁRIO}

1. INTRODUÇÃO

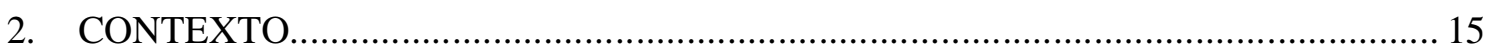

2.1. Estado Social de Direito, serviço público, delegação a particulares e o dever-poder de

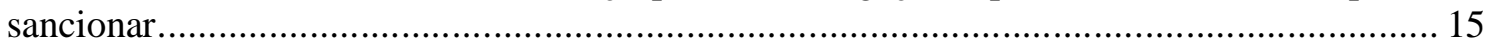

2.2. O setor elétrico brasileiro: um breve histórico e suas principais características............ 16

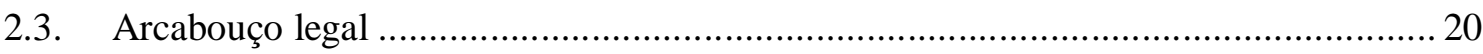

3. FISCALIZAÇÃO E IMPOSIÇÃO DE SANÇÕES NO CONTEXTO DA REGULAÇÃO

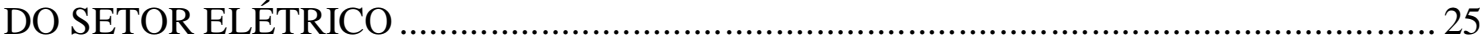

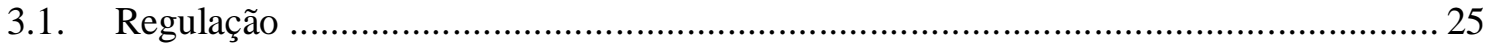

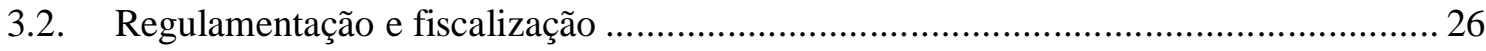

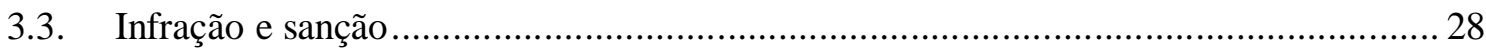

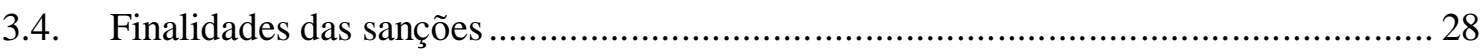

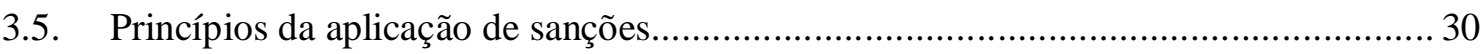

3.6. As sanções e os instrumentos de pressão da ANEEL sobre as empresas reguladas..... 33

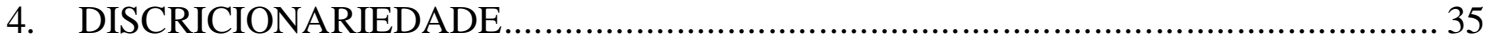

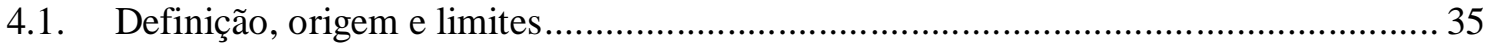

4.2. Poder normativo e autovinculação administrativa ………............................................. 36

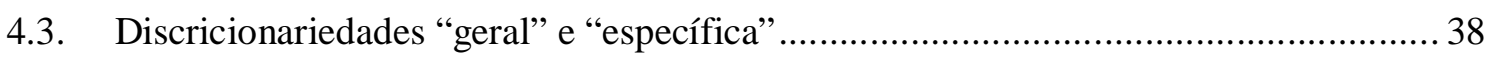

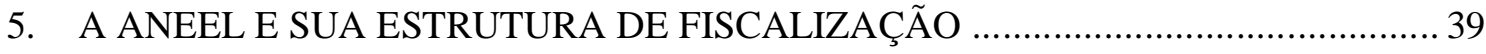

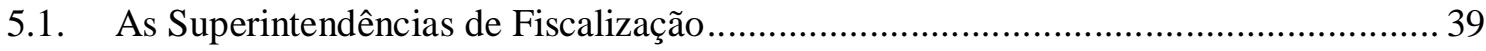

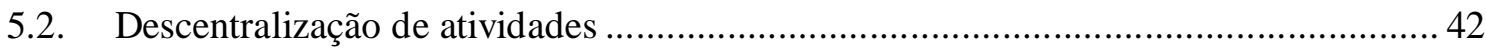

6. A ATUAL REGULAMENTAÇÃO: A RESOLUÇÃO NORMATIVA No 63/2004 ...... 46

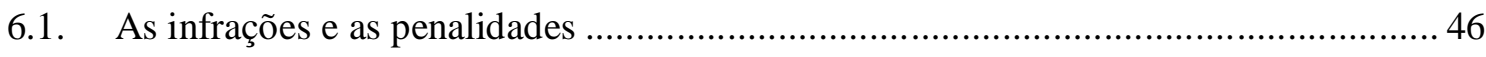

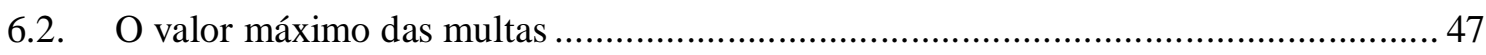

6.3. Os critérios para estabelecimento do valor das multas................................................. 49

6.4. Os procedimentos de fiscalização e de aplicação de penalidades................................... 49

7. A COMPREENSÃO E A APLICAÇÃO DA REN No 63/2004 NA DOSIMETRIA DE

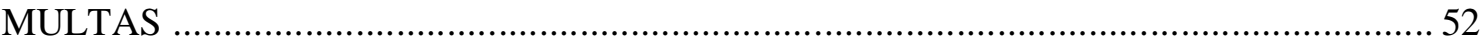

7.1. A prática da Superintendência de Fiscalização dos Serviços de Eletricidade - SFE .... 52

7.2. A prática da Superintendência de Fiscalização Econômica e Financeira - SFF ............ 54

7.3. A prática da Superintendência de Fiscalização dos Serviços de Geração - SFG.......... 57

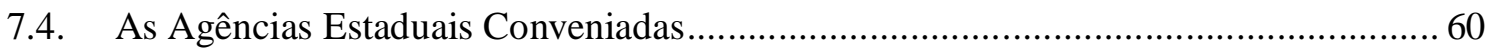

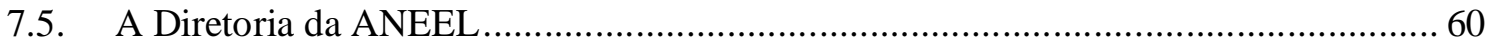

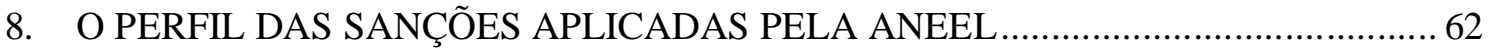




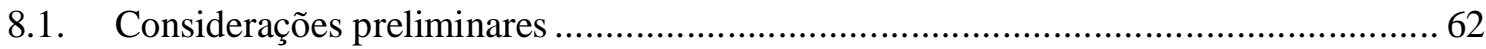

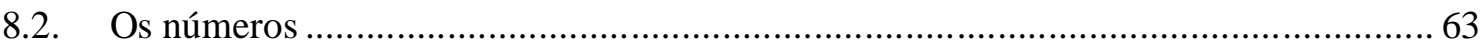

9. CONSIDERAÇÕES SOBRE A REN Nº 63/2004 E SOBRE SUA APLICAÇÃO ......... 76

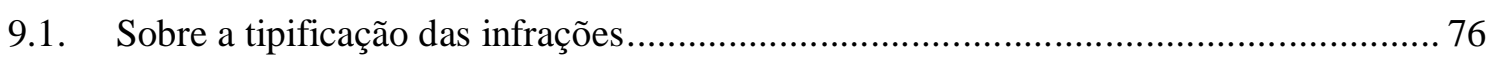

9.2. Sobre os grupos de infrações e os valores máximos das multas.................................. 80

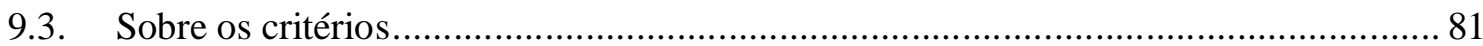

9.4. Sobre os procedimentos de fiscalização e de aplicação de penalidades...................... 83

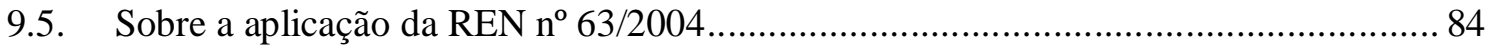

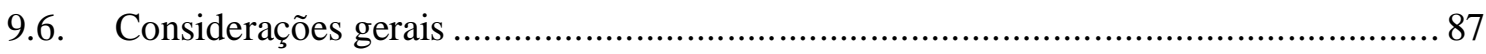

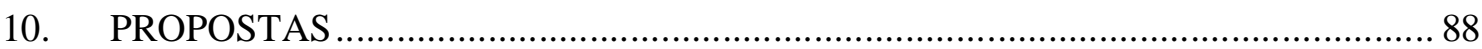

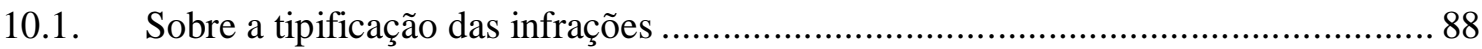

10.2. Sobre os grupos de infrações e os valores máximos das multas ............................. 89

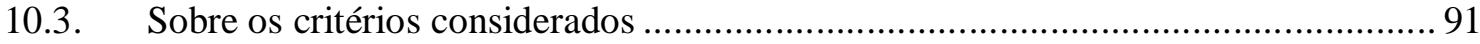

10.4. Sobre a forma de consideração dos critérios ...................................................... 92

10.5. Sobre os procedimentos de fiscalização e aplicação de penalidades....................... 94

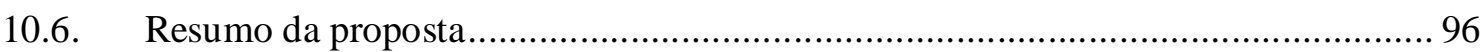

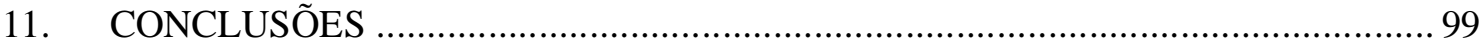

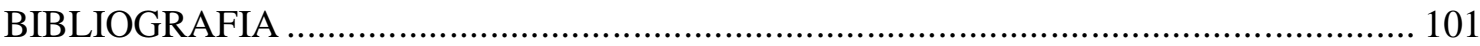

ANEXO A: RESOLUÇÃO NORMATIVA ANEEL no 63/2004 ..................................... 107 


\section{INTRODUÇÃO}

A Agência Nacional de Energia Elétrica - ANEEL é o órgão responsável por regular e fiscalizar a produção, transmissão, distribuição e comercialização de energia elétrica, em conformidade com as políticas e diretrizes do governo federal (art. $2^{\circ}$ da Lei $n^{\circ} 9.427 / 196$ ).

O mercado sob responsabilidade da Agência se constitui em um complexo ambiente econômico, em que convivem empresas públicas e privadas, capital nacional e estrangeiro e que exige investimentos de grande monta e grande prazo de maturação. Nele, elos fundamentais da cadeia de produção se configuram como monopólios naturais.

Por outro lado, seu produto último - a energia elétrica fornecida - é um insumo de essencial importância para os diversos tipos de consumidores, sendo considerado constitucionalmente no Brasil como um serviço público de competência da União (art.21, XII da Constituição Federal).

Da conjugação desses fatores se justifica a regulação exercida pela ANEEL, em que uma dinâmica essencial consiste no binômio regulamentação - fiscalização.

A efetividade da função fiscalizadora da Agência pressupõe a possibilidade de aplicação de sanções às empresas que cometem infrações à regulamentação.

As sanções administrativas são um poderoso instrumento por meio do qual a Agência reprime as empresas infratoras e previne o cometimento de infrações pelas demais. Em última análise, são um instrumento de regulação, pois funcionam como uma espécie de incentivo, ao qual se espera que as empresas respondam satisfatoriamente.

Não obstante sua importância para o bom funcionamento da regulação, o processo de imposição de sanções é bastante complexo e falhas em sua condução têm o poder de causar danos ao mercado regulado. A principal componente dessa complexidade é a discricionariedade inerente ao processo.

A atividade sancionadora da ANEEL é o objeto deste estudo, que é formado por uma análise crítica da Resolução Normativa ${ }^{\circ}$ 63, de 12 de maio de 2004, por meio da qual a Agência regulamentou o processo de imposição de sanções, e de como ela é aplicada pela estrutura de fiscalização da própria Agência.

À frente desta breve Introdução, o Capítulo 2 esclarece o contexto histórico e legal em que se amolda a atividade sancionadora da ANEEL, além de explicar brevemente os contornos atuais do ambiente regulado. 
Os Capítulos 3 e 4 compreendem a base teórica do trabalho, em que são apresentados e explorados os principais conceitos envolvidos: regulação, fiscalização, sanção e discricionariedade.

Em seguida, os Capítulos 5, 6 e 7 expõem o cenário atual, apresentando a estrutura da ANEEL dedicada à fiscalização, sua regulamentação relativa à imposição de sanções (a Resolução Normativa n 63/2004) e as práticas da Agência ao aplicá-la no ambiente por ela regulado.

O Capítulo 8 traz uma série de informações, apresentadas em forma de gráficos, que possibilitam que se conheça os principais aspectos da atividade sancionadora da Agência ao longo de seus mais de quinze anos de atividade.

O Capítulo 9 traz considerações sobre o cenário apresentado nos Capítulos 5, 6 e 7, apoiadas em conceitos do direito administrativo sancionador e da regulação econômica, isto é, na efetividade da regulamentação e de sua aplicação como incentivo ao cumprimento das normas e ao bom funcionamento do mercado de energia elétrica.

Por sua vez, o Capítulo 10 apresenta sugestões de melhoria para a Resolução Normativa $n^{\circ}$ 63/2004, calcadas na simplificação do processo, em sua objetividade e, principalmente, no uso comedido da discricionariedade do regulador.

Por fim, o Capítulo 11 resume as conclusões e propostas elaboradas ao longo do texto. 


\section{CONTEXTO}

Este Capítulo descreve sucintamente as origens do Estado Social de Direito e da prestação de serviços públicos de formas direta e delegada, estando esta última associada à atividade sancionadora. Expõe, também brevemente, o setor elétrico em termos de sua evolução e sua atual estrutura. Por fim, apresenta o arcabouço legal relacionado ao estabelecimento de sanções às empresas que atuam nesse setor.

\subsection{Estado Social de Direito, serviço público, delegação a particulares e o dever- poder de sancionar}

Foi a Revolução Francesa (1789-1799) o movimento fundamental para o lançamento das bases do Estado de Direito na França e na Europa Ocidental, modelo apto a encerrar o chamado Ancien Régime. A despeito do notável avanço que representou na defesa das liberdades individuais, sua concepção liberal de Estado Mínimo acabou por gerar grandes concentrações de riquezas e acentuar as desigualdades. Os indivíduos deixaram de ser subjugados pelo poder político para passar a sê-lo pelo poder econômico.

Datam do fim século XIX as teorias solidaristas que, impulsionadas por movimentos sociais, acrescentaram direitos fundamentais ao modelo, culminando no surgimento do Estado Social de Direito, ou Welfare State, em inglês. Nessa nova concepção, o Estado passou a ter como encargo prestações positivas, o que se deu por meio de profundas intervenções no campo econômico e social, com o objetivo de prover garantias mínimas aos indivíduos.

Por fim, foi também na França que cristalizou-se o conceito de Serviço Público, que, com adequações foi incluído no sistema normativo de muitas nações. No caso do Brasil, nas palavras de Dal Pozzo (2012),

Serviço Público é toda atividade de oferecimento de utilidade ou comodidade material destinada à satisfação da coletividade em geral, mas fruível singularmente pelos administrados, que o Estado assume como pertinente a seus deveres e presta por si mesmo ou por quem lhe faça as vezes, sob um regime de direito público - portanto, consagrador de prerrogativas de supremacia e de restrições especiais -, instituído em favor dos interesses definidos como públicos no sistema normativo.

A partir de meados do século XX, com o aumento da complexidade econômica e demonstrações de "incapacidade empresarial" dos Estados, começou a tomar forma o Estado 
Regulador, no qual a prestação dos serviços foi paulatinamente delegada a particulares. No Brasil, essa tendência confirmou-se na década de 1990, com o Programa Nacional de Desestatização - PND ${ }^{1}$.

Importante notar que o que ocorreu não foi um retorno ao Estado Mínimo, uma vez que o Estado brasileiro não renunciou à obrigação de garantir a prestação dos serviços públicos, o que mudou foi a forma de fazê-lo. A doutrina é unânime em afirmar que o que se delega é apenas a prestação, permanecendo a titularidade do serviço irrenunciável.

Nesse contexto, é da conjugação do "dever de prestar" com a "delegação da prestação" a que está sujeita o Estado que surge o dever-poder de regular, controlar e fiscalizar as atividades das empresas delegadas.

Por fim, em decorrência das atividades de controle e fiscalização do Estado é que se fundamenta seu indispensável poder de sancionar. Segundo Bittencourt (2006),

Seria inútil o dever-poder de fiscalizar, controlar e formular exigências, no curso da execução do contrato, se não houvesse a correspondente competência sancionatória em decorrência das falhas ou inadimplementos da concessionária.

A organização do setor elétrico brasileiro, como se verá na seção seguinte, segue essa lógica: a da delegação de atividades de competência do Estado a particulares, o que faz com que, na linha do raciocínio exposto, tenha cabimento e relevância o estudo das sanções administrativas em seu meio.

\subsection{O setor elétrico brasileiro: um breve histórico e suas principais características}

A utilização da energia elétrica teve seu inicio no Brasil no fim do século XIX, por meio de pequenas usinas térmicas a lenha e hidrelétricas associadas a sistemas de iluminação pública locais. A primeira usina hidrelétrica entrou em operação no ano de 1883, no Município de Diamantina, Minas Gerais, por autorização direta de Dom Pedro II a Thomas A. Edison (Pagliardi \& Sobreiro Dias, 2011).

No início do século seguinte, grande expansão se deu com a entrada de capital estrangeiro privado, principalmente norte-americano e canadense, atendendo a um processo de urbanização e de incipiente industrialização no país. Foi criada a Tramway, Light and Power Company, que explorou, entre outros serviços, a cadeia geração/transmissão/distribuição de energia elétrica nos centros urbanos de São Paulo e Rio

\footnotetext{
${ }^{1}$ Para mais informações sobre o PND, ver "VIOLA, Ricardo Rocha. Breve análise acerca do PND - Programa Nacional de Desestatização".
} 
de Janeiro. As três primeiras décadas do século XX foram marcadas também pela ausência de uma legislação específica para o setor, sendo que as relações entre as empresas e o poder público davam-se em qualquer de suas esferas: municipal, estadual ou federal.

Com a Grande Depressão de 1929 e o escasseamento do capital estrangeiro, foi publicado em 1934 o "Código de Águas" (Decreto n 24.643), que atribuiu à União o poder de autorizar ou conceder o aproveitamento de energia hidráulica, bem como outras fontes, para efeito de aproveitamento industrial. Essa norma anunciava uma nova fase para o setor, com protagonismo do Estado.

De fato, a partir da década de 1930 o governo federal assumiu forte postura intervencionista no setor e, com a criação de empresas públicas como a Companhia Hidro Elétrica do São Francisco - CHESF (1945) e a Centrais Elétricas Brasileiras S.A.ELETROBRAS (1962), entre outras empresas federais e também estaduais, o setor se desenvolveu primordialmente com capital público.

Com o regime de remuneração do "serviço pelo custo" estabelecido na década de 1970, o setor elétrico continuou sua expansão até o esgotamento do modelo, com a crise dos países em desenvolvimento no fim dos anos 1980 e a diminuição dos investimentos nos anos 1990.

Entre 1990 e 2000 o consumo de energia elétrica cresceu $49 \%$ e a oferta $33 \%$ (Albuquerque, 2008). Esses números evidenciavam a deterioração da garantia do suprimento de energia.

Entre 1995 e 2005 foram levadas a cabo duas reformas, que buscaram reinserir o investimento privado no setor. Nessa década o setor foi radicalmente reestruturado, por meio do Programa Nacional de Desestatização - PND e do Projeto de Reestruturação do Setor Elétrico Brasileiro - RE-SEB. As atividades de geração, transmissão e distribuição tornaramse áreas de negócio independentes (desverticalização), uma parte das empresas foi entregue à iniciativa privada e foram criados a ANEEL, o Operador Nacional do Sistema - ONS e o Mercado Atacadista de Energia - MAE, este último posteriormente substituído pela Câmara de Comercialização de Energia Elétrica - CCEE. Em 2004 foi criada a Empresa de Pesquisa Energética - EPE.

Com a primeira reforma (1995-2003) o setor elétrico brasileiro passou a contar com a maioria dos elementos de um mercado regulado clássico: um regulador, um operador independente, um operador de mercado a granel e separação funcional entre geração, transmissão, distribuição e comercialização (Pagliardi \& Sobreiro Dias, 2011). 
Severas secas forçaram o país, dono de um parque gerador predominantemente hidrelétrico, a enfrentar uma crise com a necessidade de racionamento de energia em 2001, em decorrência do qual, com o intuito de garantir o equilíbrio entre oferta e demanda, a segunda reforma (2004-2005) introduziu os leilões regulados e os contratos de longo prazo.

Assim, os investimentos em geração e a garantia de abastecimento ao mercado cativo passaram a ser obtidos por meio de leilões realizados pelo governo, em que as distribuidoras de energia são obrigadas a contratar $100 \%$ de sua carga. Além desse Ambiente de Contratação Regulado - ACR, foi sedimentado o Livre - ACL, onde uma parcela de consumidores contrata energia por conta própria. A competição foi introduzida na geração e na comercialização. A transmissão e a distribuição são reguladas como monopólios naturais.

A partir daí o sistema começou a perceber a entrada cada vez mais significativa de outras fontes, principalmente as termelétricas a gás natural, mas também das chamadas fontes alternativas: eólicas, termelétricas a biomassa e hidrelétricas de pequeno porte, além da ainda embrionária fonte solar.

Atualmente o setor elétrico brasileiro conta com uma complexa estrutura regulatória, da qual participam diversas instituições: Poder Legislativo (Congresso Nacional), Poder Executivo (Ministério de Minas e Energia - MME), EPE, CCEE, ONS e ANEEL, além de diversas associações de empresas e consumidores.
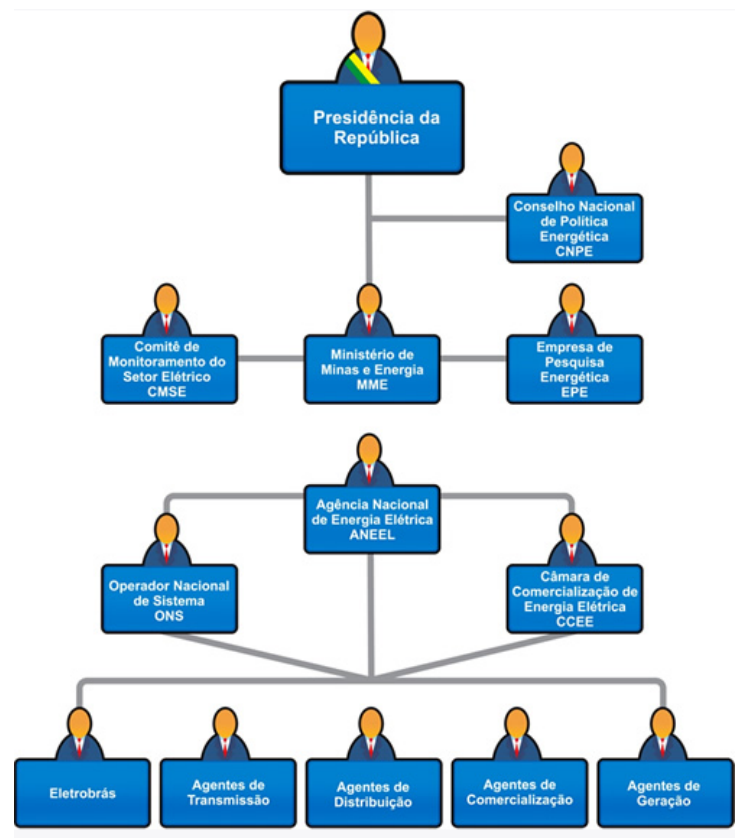

Figura 2.1 - Estrutura institucional do setor elétrico

Fonte: Associação Brasileira de Distribuidores de Energia Elétrica - ABRADEE 
As empresas reguladas (públicas e privadas, de capital nacional e estrangeiro) estão divididas entre as atividades de geração, transmissão, distribuição e comercialização de energia. O Brasil possui aproximadamente $126 \mathrm{GW}$ de capacidade instalada de geração e mais 36 GW em implantação, com previsão de conclusão até 2020. A malha de transmissão tem mais de $100.000 \mathrm{~km}$ de extensão e outros 42.000 devem ser implantados até 2020. A distribuição atende mais de 73 milhões de unidades consumidoras. $\mathrm{O}$ setor movimentou em 2012, só na venda de energia no ACR, aproximadamente 94 bilhões de reais (ANEEL, 2013).

O diagrama da Figura 2.2 resume os números atuais do setor.
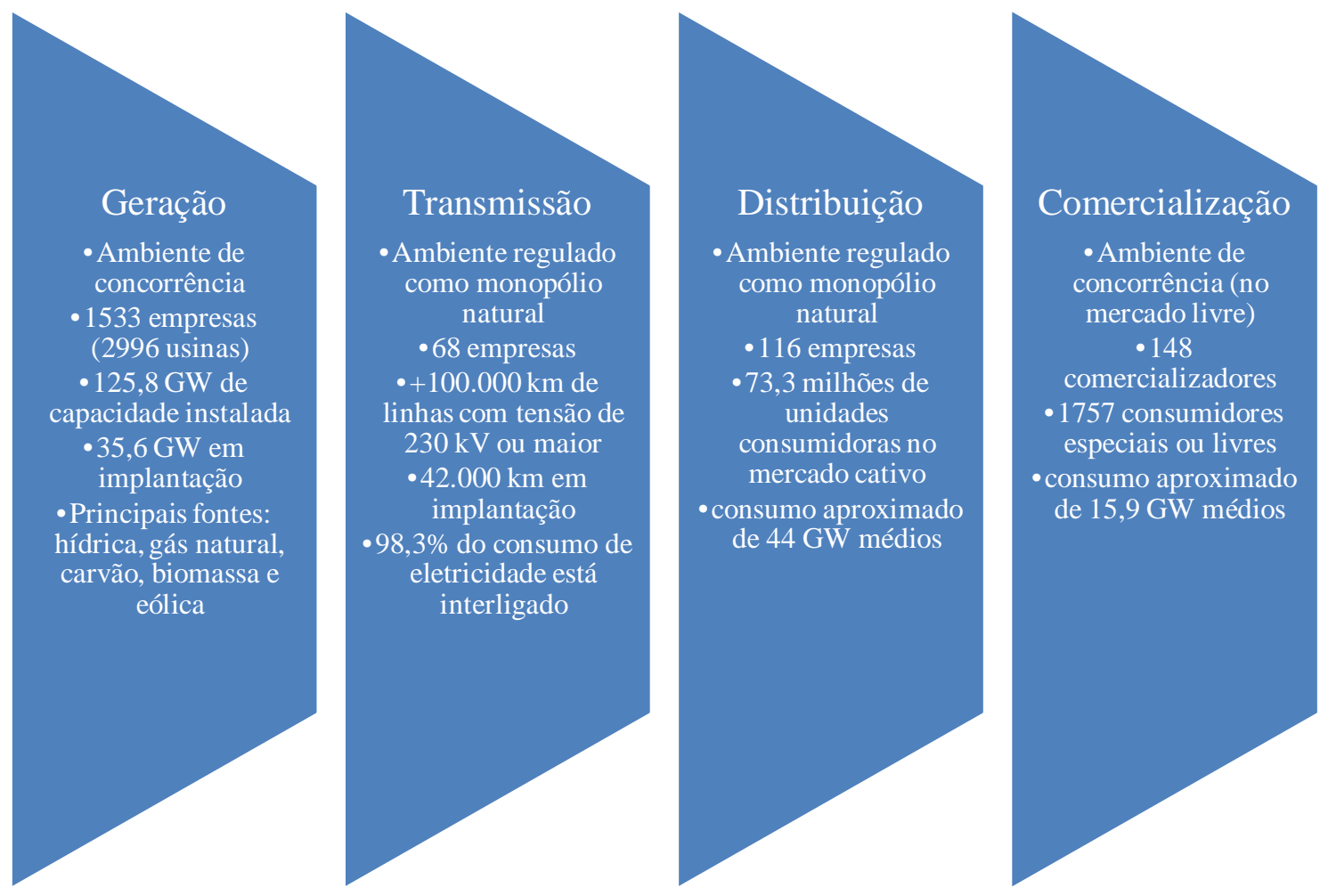

Figura 2.2 - Principais atividades na cad eia de produção de energia elétrica

Fonte: Elaboração própria com dados da ANEEL, do ONS e da CCEE 


\subsection{Arcabouço legal}

A Constituição da República Federativa do Brasil, de 1988, prevê, em seu artigo 21, os serviços públicos de competência da União, entre eles os referentes à energia elétrica, conforme segue:

Art. 21. Compete à União:

$[\ldots]$

XII - explorar, diretamente ou mediante autorização, concessão ou permissão:

$[\ldots]$

b) os serviços e instalações de energia elétrica e o aproveitamento energético dos cursos de água, em articulação com os Estados onde se situam os potenciais hidroenergéticos;

[...]

\section{O artigo 37 da Carta determinou que:}

Art. 37. A administração pública direta e indireta de qualquer dos Poderes da União, dos Estados, do Distrito Federal e dos Municípios obedecerá aos princípios de legalidade, impessoalidade, moralidade, publicidade e eficiência e, também, ao seguinte:

$[\ldots]$

XXI - ressalvados os casos especificados na legislação, as obras, serviços, compras e alienações serão contratados mediante processo de licitação pública que assegure igualdade de condições a todos os concorrentes, com cláusulas que estabeleçam obrigações de pagamento, mantidas as condições efetivas da proposta, nos termos da lei, o qual somente permitirá as exigências de qualificação técnica e econômica indispensáveis à garantia do cumprimento das obrigações.

O artigo 175 trouxe, por sua vez, condições para a delegação da prestação dos serviços públicos a particulares e requisitos que devem ser respeitados nessa dinâmica:

Art. 175. Incumbe ao Poder Público, na forma da lei, diretamente ou sob regime de concessão ou permissão, sempre através de licitação, a prestação de serviços públicos.

Parágrafo único. A lei disporá sobre:

I - o regime das empresas concessionárias e permissionárias de serviços públicos, o caráter especial de seu contrato e de sua prorrogação, bem como as condições de caducidade, fiscalização e rescisão da concessão ou permissão;

II - os direitos dos usuários;

III - política tarifária;

IV - a obrigação de manter serviço adequado.

A Lei $n^{\circ} 8.666 / 1993$ regulamentou o inciso XXI do artigo 37 da Constituição e, no artigo 87 de sua Seção II "Das Sanções Administrativas", dispôs:

Art. 87. Pela inexecução total ou parcial do contrato a Administração poderá, garantida a prévia defesa, aplicar ao contratado as seguintes sanções: 
I - advertência;

II - multa, na forma prevista no instrumento convocatório ou no contrato;

III - suspensão temporária de participação em licitação e impedimento de contratar com a Administração, por prazo não superior a 2 (dois) anos;

IV - declaração de inidoneidade para licitar ou contratar com a Administração Pública enquanto perdurarem os motivos determinantes da punição ou até que seja promovida a reabilitação perante a própria autoridade que aplicou a penalidade, que será concedida sempre que o contratado ressarcir a Administração pelos prejuízos resultantes e após decorrido o prazo da sanção aplicada com base no inciso anterior.

$[\ldots]$

§ 30 A sanção estabelecida no inciso IV deste artigo é de competência exclusiva do Ministro de Estado, do Secretário Estadual ou Municipal, conforme o caso, facultada a defesa do interessado no respectivo processo, no prazo de 10 (dez) dias da abertura de vista, podendo a reabilitação ser requerida após 2 (dois) anos de sua aplicação.

A Lei $n^{\circ} 8.987 / 1995$ regulamentou o artigo 175 da Carta e instituiu parâmetros para descrever, no $\S 1^{\circ}$ de seu artigo $6^{\circ}$, o que a Constituição chamou de "serviço adequado". Esses parâmetros constituíram a base para a avaliação da conduta das empresas delegadas.

$\S 1^{\circ}$ Serviço adequado é o que satisfaz as condições de regularidade, continuidade, eficiência, segurança, atualidade, generalidade, cortesia na sua prestação e modicidade das tarifas.

O mesmo diploma legal estabeleceu manifestações de controle do Poder Concedente sobre a prestação dos serviços. Segundo Di Pietro (1999),

Previsão genérica de fiscalização pelo poder concedente, com a cooperação dos usuários (art. $3^{\circ}$;

1. Competência do poder concedente para fiscalizar permanentemente a prestação do serviço (art. 29, I);

2. Competência do poder concedente para cumprir e fazer cumprir as disposições regulamentares do serviço e as cláusulas contratuais e zelar pela boa qualidade do serviço (art. 29, V e VII);

3. Direito de acesso aos dados relativos à administração, contabilidade, recursos técnicos, econômicos e financeiros da concessionária (art. 30);

4. Direito de acesso, em qualquer hora, às obras, aos equipamentos e às instalações integrantes do serviço, bem como aos seus registros contábeis (art. 31, V).

A Lei $n^{\circ}$ 8.987/1995 dispôs também sobre os encargos do poder concedente. Entre eles o de aplicar as penalidades regulamentares e contratuais (art. 29, II) e estabeleceu que $a$ inexecução total ou parcial do contrato acarretará, a critério do poder concedente, a declaração de caducidade da concessão ou a aplicação das sanções contratuais [...] (art. 38).

A Lei $n^{\circ}$ 9.427/1996, que instituiu a Agência Nacional de Energia Elétrica com a finalidade de regular e fiscalizar a produção, transmissão, distribuição e comercialização de 
energia elétrica, em conformidade com as políticas e diretrizes do governo federal (art. $2^{\circ}$ ), definiu entre suas atribuições as de

gerir os contratos de concessão ou de permissão de serviços públicos de energia elétrica, de concessão de uso de bem público, bem como fiscalizar, diretamente ou mediante convênios com órgãos estaduais, as concessões, as permissões e a prestação dos serviços de energia elétrica [...], regular o serviço concedido, permitido e autorizado e fiscalizar permanentemente sua prestação [...], fixar as multas administrativas a serem impostas aos concessionários, permissionários e autorizados de instalações e serviços de energia elétrica [...] (art. $3^{\circ}$, IV, XIX e X).

Sobre as multas administrativas de competência da ANEEL, a Lei nº 9.427/1996 fixou seu valor máximo em $2 \%$ do faturamento anual da empresa, por infração.

Essas disposições foram posteriormente reafirmadas no Decreto $\mathrm{n}^{\circ} 2.335 / 1997$, que aprovou a estrutura regimental da ANEEL e em sua Seção II, detalhou os objetivos da ação fiscalizadora da Agência e as sanções por ela passiveis de serem aplicadas, conforme segue: Seção II Da Fiscalização

Art. 16. A ação fiscalizadora da ANEEL visará, primordialmente, à educação e orientação dos agentes do setor de energia elétrica, à prevenção de condutas violadoras da lei e dos contratos e à descentralização de atividades complementares aos Estados, com os propósitos de:

I - instruir os agentes e consumidores quanto ao cumprimento de suas obrigações contratuais e regulamentares;

II - fazer cumprir os contratos, as normas e os regulamentos da exploração dos serviços e instalações de energia elétrica;

III - garantir o atendimento aos padrões de qualidade, custo, prazo e segurança compatíveis com as necessidades regionais e específicas de cada categoria de agente envolvido;

IV - garantir o atendimento aos requisitos de quantidade, adequação e finalidade dos serviços e instalações de energia elétrica;

V - subsidiar, com informações e dados necessários, a ação regulatória, visando à modernização do ambiente institucional de atuação da ANEEL.

$[\ldots]$

Art. 17. A ANEEL adotará, no âmbito das atividades realizadas pelos agentes do setor de energia elétrica, em conformidade com as normas regulamentares e os respectivos contratos, as seguintes penalidades a serem aplicadas pela fiscalização:

I - advertência escrita, por inobservância a determinações da fiscalização ou de normas legais;

II - multas em valores atualizados, nos casos previstos nos regulamentos ou nos contratos, ou pela reincidência em fato que tenha gerado advertência escrita;

III - suspensão temporária de participação em licitações para obtenção de novas concessões, permissões ou autorizações, bem como impedimento de contratar com a Autarquia, em caso de 
não execução total ou parcial de obrigações definidas em lei, em contrato ou em ato autorizativo;

IV - intervenção administrativa, nos casos previstos em lei, no contrato, ou em ato autorizativo, em caso de sistemática reincidência em infrações já punidas por multas;

V - revogação da autorização, nos termos da legislação vigente ou do ato autorizativo;

VI - caducidade da concessão ou permissão, na forma da lei e do respectivo contrato.

$\S 1^{\circ}$ A ANEEL definirá os procedimentos administrativos relativos à aplicação de penalidades, de cobrança e pagamento das multas legais e contratuais, assegurados o contraditório e o direito de ampla defesa.

[...]

$\S 4^{\circ}$ As multas serão graduadas segundo a natureza e a gravidade das infrações e aplicadas em múltiplos, conforme dispuser o respectivo regulamento da ANEEL, nos casos de reincidência, podendo ser cumuladas com outras penalidades.

[...]

Há que se mencionar ainda o disposto no inciso no artigo $2^{\circ}$ da Lei $n^{\circ} 9.784 / 1999$, sobre os princípios que regem o processo administrativo no âmbito da administração pública.

Art. $2^{\circ}$ A Administração Pública obedecerá, dentre outros, aos princípios da legalidade, finalidade, motivação, razoabilidade, proporcionalidade, moralidade, ampla defesa, contraditório, segurança jurídica, interesse público e eficiência.

Tratando-se do processo de imposição de sanções administrativas, é especialmente importante a condição imposta no inciso VI do parágrafo único do mesmo artigo.

Parágrafo único. Nos processos administrativos serão observados, entre outros, os critérios de:

$[\ldots]$

VI - adequação entre meios e fins, vedada a imposição de obrigações, restrições e sanções em medida superior àquelas estritamente necessárias ao atendimento do interesse público;

$[\ldots]$

Vê-se que há um arcabouço legal extenso versando sobre as obrigações de fiscalização, sobre o dever-poder sancionador e sobre as condições da atuação do poder concedente, hoje representado pela ANEEL, frente aos agentes delegados que prestam serviços de energia elétrica no país. O diagrama a seguir destaca seus aspectos principais. 
- Estabelece os serviços de energia elétrica como de competência da União

- Exige serviço adequado

- Permite delegação a particulares

- Define sanções administrativas possíveis aos delegatários: advertência, multa, suspensão e declaração de inidoneidade

- Define o conceito de serviço adequado: regularidade, continuidade, eficiência, segurança, atualidade, generalidade, cortesia e modicidade

- Estabelece como encargo do poder concedente a aplicação de sanções

- Cria a ANEEL e dá a ela competência para fiscalizar e aplicar sanções aos delegatários

- Define o limite máximo das multas em $2 \%$ do faturamento anual da empresa

- Estabelece os objetivos da fiscalização: instruir, previnir, fazer cumprir, garantir padrões e subsidiar a regulamentação

- Descreve as sanções que competem à ANEEL: advertência, multa, suspensão, intervenção, revogação e caducidade

- Define critérios de gradação: natureza, gravidade e reincidência

- Regula o processo administrativo: legalidade, finalidade, motivação, razoabilidade, proporcionalidade, moralidade, ampla defesa, contraditório, segurança jurídica, interesse público e eficiência

- Veda a imposição de sanções que excedam o interesse público

Figura 2.3 - Destaques da legislação no processo de imposição de penalidades pela ANEEL

Fonte: Elaboração própria

É sobre essa base legal que a ANEEL apoia a legitimidade de seus atos normativos. O Capítulo 6 deste trabalho mostra como a ANEEL, em atendimento ao $\S 1^{\circ}$ do artigo 17 do Decreto $n^{\circ}$ 2.335/1997, regulamentou, por meio da Resolução Normativa $n^{\circ}$ 63, de 12 de maio de 2004, os procedimentos para imposição de sanções. 


\section{FISCALIZAÇÃO E IMPOSIÇÃO DE SANÇÕES NO CONTEXTO DA REGULAÇÃO DO SETOR ELÉTRICO}

Este Capítulo apresenta o a ideia de regulação e sua dinâmica "regulamentação fiscalização". Define também os conceitos de infração e sanção, bem como apresenta as finalidades destas últimas e os princípios que devem nortear sua aplicação. Ao fim, são apresentados os tipos de sanção e outros instrumentos de pressão efetivamente utilizados pela ANEEL na regulação das empresas do setor elétrico.

\subsection{Regulação}

No contexto da transferência de atividades de competência da União a empresas privadas (e, no caso brasileiro, também a empresas públicas), tem-se hoje a versão nacional do conceito de Estado Regulador.

Regulação, para Moreira (1997),

é o estabelecimento e a implementação de regras para a atividade econômica destinadas a garantir o seu funcionamento equilibrado, de acordo com determinados objetivos públicos.

Na definição de Sundfeld (2000),

A regulação é - isso, sim - característica de um certo modelo econômico, aquele em que o Estado não assume diretamente o exercício de atividade empresarial, mas intervém enfaticamente no mercado utilizando instrumentos de autoridade. Assim, a regulação não é própria de certa família jurídica, mas sim de uma opção de política econômica.

Em texto da Associação Brasileira das Agências Reguladoras - ABAR citado por Borges (2005),

A moderna noção de regulação remete-se à ideia de equilíbrio dentro de um dado sistema regulado. Esse poderá envolver a introdução de interesses gerais externos ao sistema, que deverão ser processados pelo regulador de forma que a sua consecução não acarrete a inviabilidade do setor regulado.

Esse equilíbrio do regulador deve situar-se em um ponto equidistante entre três principais interessados em suas ações: o governo, as empresas reguladas e os consumidores do serviço prestado. Segundo Tavares (2003),

Tal equidistância, altamente dinâmica, é resultante da relação "órgão regulador - regulados", e se constitui no processo de regulação propriamente dito, que consiste na supervisão, controle e, 
se necessário, na interferência, de alguma maneira nas atividades sujeitas à regulação, determinando e/ou modificando comportamentos (controle externo).

A presença do ente regulador faz-se especialmente necessária em um contexto em que, além da delegação da atividade de competência do Estado a terceiros, existem falhas de mercado e o serviço é considerado essencial. Essa é a realidade da prestação de serviços no setor elétrico do Brasil, em que se justifica a atuação da ANEEL.

\subsection{Regulamentação e fiscalização}

Uma dinâmica essencial da atividade regulatória diz respeito ao binômio "regulamentação - fiscalização": primeiro define-se as regras e depois verifica-se seu cumprimento. A legitimidade dessas ações se fortalece quando as regras são definidas com participação dos setores interessados e quando a verificação de seu cumprimento, acompanhada da possibilidade de imposição de sanções, é feita por meio do devido processo legal.

O ganho na relação entre as duas atividades é maximizado quando as informações que a fiscalização captura no ambiente regulado retroalimentam as ações de regulamentação, promovendo sua melhoria contínua.

Adicionalmente, o monopólio natural em que se desenha a prestação das atividades de transmissão e distribuição, bem como o caráter essencial do fornecimento de energia elétrica justificam a necessidade de intensa fiscalização por parte do regulador, a fim de evitar práticas abusivas da parte de seus delegatários.

Um dos principais problemas da regulação é a garantia da qualidade do serviço prestado. É a esse objetivo (qualidade dos serviços de geração, transmissão e distribuição) que se dedica grande parte da atividade de fiscalizadora da ANEEL, bem como é sobre esse tema que versam a maioria das punições exaradas.

Nas palavras de Ghirardi (2000),

Um dos problemas mais difíceis dentro do sistema de prestação de serviços de energia elétrica sob regime de concessão refere-se à garantia da qualidade do serviço. Os contornos da questão são claros: cabe ao Estado, através do agente regulador, estabelecer o preço permissível e definir os padrões mínimos de prestação dos serviços, controlando o desempenho da empresa concessionária dentro desses padrões. Apesar da aparência simples, a prática desta incumbência apresenta grande complexidade, à medida que exige a contínua reavaliação de um equilíbrio entre interesses que são, em certa medida, conflitantes. Espera-se que o órgão regulador estabeleça, por um lado, um preço que propicie retorno atraente e induza 
investimentos, num ambiente de negócios em permanente transformação e sujeito a consideráveis oscilações conjunturais. Uma vez estabelecido o preço pelo serviço e os padrões mínimos de qualidade, a empresa concessionária fará todos os esforços para reduzir os custos e obter a maior remuneração possível sobre o investimento. Diante disso, espera-se também que o agente regulador mantenha sob controle esses esforços redutores de custos, impondo com rigor o cumprimento das cláusulas de qualidade que resguardam o interesse do consumidor [...] Nesta aparente contradição dos interesses envolvidos é que reside a dificuldade em garantir o nível adequado de qualidade na prestação de serviços.

Para Borges (2005),

Resolver este conflito entre o lucro e a qualidade dos serviços prestados não é uma tarefa fácil. Além das variáveis intrínsecas do setor elétrico, deve-se atentar para as externalidades políticas, econômicas e sociais que podem influir sobre o comportamento das empresas concessionárias, do Órgão Regulador e do próprio consumidor, impondo ao regulador a necessidade de ter uma visão mais global do cenário energético brasileiro.

Segundo o mesmo autor,

A regulação é um processo dinâmico, por isso exige a atuação pró-ativa das agências. A fiscalização é um instrumento de apoio à consolidação das regras, com o objetivo de promover o desenvolvimento eficaz do setor elétrico, fornecendo informações que possibilitem a constatação dos fatos e acontecimentos, atuando como feedback para as ações da regulação na verificação da aderência dos atos aos dispositivos legais e promovendo efetivamente o funcionamento harmônico do modelo setorial.

Como dito, a possibilidade de imposição de sanções é parte essencial desse sistema. Segundo José Eduardo Pinheiro Santos Tanure (2004),

A regulamentação associada ao segmento monopolista pressupõe a existência de punição associada à inobservância de regulamentos, de tal forma que o titular do monopólio seja desestimulado à realização de práticas abusivas. Além da regulamentação associada à punição, é possível tratar os agentes com uma ótica "pró-ativa" criando incentivos que induzam suas práticas no sentido de maior eficiência global para a economia onde se encontram inseridas.

Existe, portanto, uma necessidade de sintonia entre as atividades de regulamentação e de fiscalização para e execução da boa regulação: enquanto as normas precisam ser construídas de maneira a atender tanto as condições de qualidade do serviço como a manutenção de um cenário de incentivos coerente e atraente para as empresas, a verificação de seu cumprimento precisa ser de tal modo eficiente que dissuada as empresas de infringi-las e puna eficazmente as que assim procedem, além de subsidiar, com informações do ambiente regulado, a melhoria e a atualização das próprias normas. 


\subsection{Infração e sanção}

Infração administrativa é o descumprimento voluntário de uma norma administrativa para o qual se prevê sanção cuja imposição é decidida por uma autoridade no exercício de função administrativa.

Sanção administrativa ${ }^{2}$ é a providência gravosa prevista em caso de incursão de alguém em uma infração administrativa cuja imposição é da alçada da própria Administração.

Nas palavras de Reale, (1985) sanção é a consequência predeterminada pelo ordenamento jurídico ao descumprimento de uma norma.

De modo semelhante, Ferraz Júnior (2008) interpreta a sanção jurídica como sendo consequência ou efeito jurídico preceituado por normas e define que a sanção jurídica é considerada um elemento importante, e se aceita que, por característica, sempre vem prescrita por normas, embora nem todas prescrevam sanções.

Nessa linha de raciocínio, Faria (2007) entende sanção administrativa como uma medida punitiva imposta pela Administração no caso de violação de uma norma jurídicoadministrativa.

Vieira (2010) explica, pela ótica do direito, que,

A identificação e a apuração de infrações administrativas e a aplicação concreta das sanções administrativas pelo ente público aos contratados faltosos é uma das cláusulas exorbitantes do contrato administrativo ${ }^{3}$. Essas cláusulas decorrem da posição de supremacia da administração perante o particular contratado e são reflexo do princípio da supremacia do interesse público sobre o privado, que fornece à administração diversas prerrogativas, de direito material e processual.

\subsection{Finalidades das sanções}

As sanções estão entre os principais instrumentos de que o Estado lança mão para punir e, principalmente, para prevenir condutas infratoras. De maneira geral, um sistema sancionador pode ser considerado eficaz e eficiente se reduz no maior grau possível o número

\footnotetext{
${ }^{2}$ Neste trabalho, os termos "sanção" e "penalidade" são considerados equivalentes.

${ }^{3}$ Contrato Administrativo (ou Contrato Público) é um instrumento que a Administração utiliza para dirigir-se e atuar perante seus administrados sempre que necessita adquirir bens ou serviços de particulares. No caso específico do setor elétrico são firmados Contratos de Concessão e de Permissão de prestação de serviços. Para uma parte das atividades é adotado um rito simplificado, em que é emitida apenas uma Autorização. Esta se configura como um ato administrativo discricionário, unilateral e precário, e nas relações assim regidas, também se faz presente "a posição de supremacia da administração perante o particular".
} 
de infrações no setor regulado, ao menor custo global (considerando quem aplica, quem recebe as sanções e os usuários do serviço).

A disciplina do direito administrativo sancionador empresta valiosos elementos do direto penal para fundamentar sua teoria. Segundo Gabriel Moreira Pinto (2010),

É claro que "pena" e "sanção administrativa" são institutos diferentes, mas ambas possuem muitos pontos de identidade, de modo que a analogia pode ajudar a suprir parte da lacuna sobre o tema na literatura concorrencial. Afinal, no antitruste, a importância da multa também decorre de uma dupla finalidade: preventiva e retributiva.

No âmbito da regulação do setor de eletricidade, o mesmo se pode dizer a respeito, tanto da semelhança entre "pena" e "sanção", quanto da lacuna na literatura.

Segundo Carvalho Neto (2008),

No direito penal, a finalidade preventiva [da sanção] tem a função de deter ou impedir o delito, por meio de seu efeito intimidatório sobre a coletividade, de modo a inibir o delinquente ocasional, reeducar o criminoso corrigível ou tornar inofensivo o incorrigível.

Ainda, o efeito preventivo (ou dissuasório) é potencializado com a transparência das punições impostas, pois seu efeito é sentido não só pelo infrator apenado no caso concreto, mas pelos demais agentes que atuam no ambiente regulatório.

Nessa linha, Vieira (2010) distingue prevenção especial de prevenção geral:

A aplicação das sanções administrativas tem finalidade de prevenção especial, prevenção geral e repressão. A finalidade de prevenção especial (caráter educativo e pedagógico) visa mostrar ao faltoso o cometimento do ato ilícito com a finalidade de que ele não cometa novas infrações. O caráter pedagógico geral visa demonstrar a todos os interessados da coletividade que o Poder Público é diligente na aplicação rápida das sanções e não transige quando se trata de violação de interesses públicos.

No que tange à finalidade retributiva (ou repressiva), foi no contexto do movimento iluminista do século XVIII que Beccaria (1764) primeiro afirmou que toda pena que supere a absoluta necessidade é tirânica. Nesse sentido, nas palavras de Carvalho Neto (2008),

A retribuição diz respeito à restauração da ordem atingida pelo ilícito. A grande virtude dessa abordagem encontra-se na limitação do poder do Estado, ao substituir a ideia de vingança pelo princípio da culpabilidade, de sorte que a pena deverá ser proporcional à gravidade do ilícito cometido.

Essas ideias penalistas podem ser aplicadas com facilidade no campo do direito administrativo sancionador de maneira geral e no da regulação do setor elétrico, em específico. 


\subsection{Princípios da aplicação de sanções}

Ensina a doutrina especializada que a aplicação de sanções deve ser norteada principalmente pelos princípios da legalidade, da tipicidade e da proporcionalidade.

Sobre a legalidade, significa afirmar que apenas sanções previstas em lei podem ser aplicadas pelo regulador. No entanto, essa previsão pode ser genérica, cabendo ao próprio regulador o seu detalhamento. Afirma Aragão (2002) que a aplicação de sanções deve estar apoiada em algum dispositivo legal, ainda que genérico, ficando a graduação e a especificação das penalidades a serem normatizadas pela agência.

O princípio da tipicidade compreende a necessidade de que os comportamentos reprováveis estejam descritos por uma norma legal. Aqui também se admite que as normas do regulador detalhem o que em lei foi definido de forma genérica. Nas palavras de Bittencourt (2006),

nos casos em que a tipificação anterior da infração administrativa em lei formal não seja possível, ou até mesmo impeditiva da realização do interesse público, pode-se acolher que as condutas reprováveis, genericamente previstas em lei, sejam complementadas mediante o exercício do poder normativo da Administração.

A proporcionalidade diz respeito à moderação que se exige do regulador no exercício de sua competência de sancionar. Esse princípio, nas palavras de Perez (1983, apud Bittencourt, 2006), não postula outra coisa senão uma adequação entre meios e fins. Segundo Bittencourt, deve existir, portanto, uma congruência real entre a sanção estabelecida e a finalidade de punir o infrator. É intima a relação desse conceito com a finalidade retributiva atribuída às sanções, uma vez que, ainda segundo Bittencourt,

as sanções estabelecidas são instrumentos que buscam apenas e tão-somente a compatibilização da atividade desempenhada pelo delegatário com os objetivos positivados na ordem jurídica.

Uma particularidade da regulação de serviços públicos a respeito da proporcionalidade da sanção é que multas excessivas podem afetar a saúde financeira das empresas, e terminar por prejudicar a qualidade do serviço prestado, surtindo, portanto, efeitos contrários aos almejados pelo órgão regulador com a imposição da sanção. Nesse sentido, é preciso entender as sanções como um meio, e não um fim.

Faz-se essencial discorrer também sobre os princípios jurídicos da individualização da sanção e da segurança jurídica, caros ao exercício do direito administrativo sancionador. 
O princípio da individualização da sanção tem origem no direito penal e sua aplicação equivale a dizer que o julgador deve levar em consideração as circunstâncias de cada caso concreto, explicitando-as na decisão.

\section{Segundo Dios (2006),}

[Podemos] conceituar a individualização da pena como: direito público subjetivo de todo condenado a ser submetido a uma pena compatível com seu grau de culpabilidade, atendido os limites e parâmetros estabelecidos pela lei.

A validade do principio da individualização da pena no âmbito do direito administrativo sancionador, onde se traduz como "individualização da sanção", é bastante consolidada. Nessa linha é que, por exemplo, a Lei $n^{\circ}$ 6.385/1976 determina que a Comissão de Valores Mobiliários - CVM considere, no estabelecimento de sanções, o arrependimento eficaz e o arrependimento posterior ou a circunstância de qualquer pessoa, espontaneamente, confessar ilícito ou prestar informações relativas à sua materialidade. Em sentido semelhante, o Manual de Normas e Instruções do Banco Central do Brasil determina que a autarquia deve levar em consideração, na sua atuação, as circunstâncias agravantes ou atenuantes, para efeito de aplicação de penalidade ${ }^{4}$.

Na legislação do setor elétrico, a exigência de atendimento a esse princípio é expresso no Decreto $n^{\circ}$ 2.335/1996, que impõe que a ANEEL leve em conta a reincidência da empresa infratora. A regulamentação da matéria por parte da Agência Reguladora deu ainda maior atenção a essa necessidade, como se demonstra no Capítulo 6 deste estudo.

Quanto à segurança jurídica, o próprio Estado de Direito pressupõe uma ordem jurídica com instrumentos para a defesa dos particulares frente ao poder do Estado. A própria existência do direito escrito, com previsões gerais, presta serviço à sua manutenção, provendo regras previamente definidas para a resolução dos conflitos de interesses.

Segundo Andrade (2010),

A segurança jurídica é um direito fundamental do cidadão. Implica normalidade, estabilidade, proteção contra alterações bruscas numa realidade fático-jurídica. Significa a adoção pelo estado de comportamentos coerentes, estáveis, não contraditórios. É também, portanto, respeito a realidades consolidadas.

$[\ldots]$

Toda a atuação estatal deve ser coerente, coesa, nunca contraditória. Quando um servidor ou outro agente público fala, eles falam em nome do Estado, e não se pode admitir declarações contraditórias. Há um princípio importante - também relativo à segurança jurídica - que é

\footnotetext{
${ }^{4}$ Para mais informações sobre a relação entre os princípios da individualização da pena e da isonomia, ver Barstad, A. B. S.; Costa, L. P.; Sader, M.: "Isonomia e Individualização da Pena não se Excluem".
} 
o venire contra factum proprium, ou seja, "Vedação de comportamento contraditório". Cuidase também de uma ideia de boa-fé e lealdade.

No entanto, não basta a simples existência de normas escritas para garantir o respeito à segurança jurídica, é preciso que ela seja "sentida" no ambiente de negócios.

Segundo Reale (1994),

Há, pois, que distinguir entre o "sentimento de segurança", ou seja, entre o estado de espírito dos indivíduos e dos grupos na intenção de usufruir de um complexo de garantias, e este complexo como tal, como conjunto de providências instrumentais capazes de fazer gerar e proteger aquele estado de espírito de tranquilidade e concórdia.

A segurança jurídica exige um esforço permanente do Estado em demonstrá-la e mantê-la, na execução de seus atos. Esse esforço, essa dimensão do "sentimento" é interpretada por parte da doutrina como um princípio jurídico independente, o da "proteção da confiança".

A manutenção da segurança jurídica é especialmente importante, do ponto de vista regulatório, em um ambiente de negócios onde os investimentos realizados pelas empresas são de grande monta e tem longo prazo de maturação. Esse é o caso do setor elétrico, em que a construção, por exemplo, de novas usinas de geração ou novas linhas de transmissão exige investimentos por vezes na casa dos bilhões de reais, e que tem prazos de maturação de dez anos ou mais ${ }^{5}$. Por isso, a delegação de atividades do poder público às empresas é feita em contratos com prazos de até trinta e cinco anos de duração ${ }^{6}$. Para "aceitarem apostas altas", os investidores exigem um ambiente de negócios confiável.

Especificamente quanto à aplicação de sanções, a ausência de clareza e transparência no processo pode constituir-se em perturbação da segurança jurídica do setor, uma vez que as empresas não podem prever em que medida serão punidas pelas infrações nas quais podem vir a incorrer na execução de suas atividades.

Complementarmente, há que se falar nos princípios da anteriorioridade (analogamente ao preceito penal do nullim crimen, nulla poena sine lege, também não há infração administrativa nem sanção administrativa sem prévia estatuição de uma e de outra), da

\footnotetext{
${ }^{5}$ Moreira (2008) estimou o investimento necessário para a implantação de uma usina de 1.000 MW no Brasil em US\$ 1.250,00/kW (fonte hidráulica), US\$ 1.100,00/kW (fonte biomassa), US\$ 900,00/kW (fonte gás natural) e US\$ 2.00,00/kW (fonte eólica). A título de exemplo, O Globo informa que, segundo dados das empresas e do Balanço do PAC, os investimentos totais na construção das usinas hidrelétricas de Santo Antonio (3.150 MW) e Jirau (3.750 MW), no Rio Madeira (RO) serão de R \$ 15,1 e R\$ 15,5 bilhões, respectivamente. Segundo o Portal Brasil, seu sistema de transmissão associado exigirá um investimento R $\$ 7,2$ bilhões.

${ }^{6}$ A Lei $n^{\circ} 9.074 / 1995$ previu prazo de concessão de até trinta e cinco anos, prorrogável por mais vinte, para empreendimentos de geração (art. $4^{\circ}$, § $2^{\circ}$, com redação dada pela Lei ${ }^{\circ} 10.848 / 2004$ ), e de até trinta anos, prorrogável por igual período, para empreendimentos de transmissão e distribuição de energia elétrica $\left(\operatorname{art} .4^{\circ}, \S\right.$ $\left.3^{\circ}\right)$.
} 
motivação (a Administração é obrigada a expor os fundamentos em que está embasada para aplicar a sanção) e do devido processo legal (segundo o inciso LV do $\operatorname{artigo} 5^{\circ}$ da Constituição Federal, aos litigantes, em processo judicial ou administrativo, e aos acusados em geral são assegurados o contraditório e a ampla defesa, com os meios e recursos a ela inerentes).

\subsection{As sanções e os instrumentos de pressão da ANEEL sobre as empresas reguladas}

As sanções administrativas estão entre as ferramentas disponíveis à ANEEL para pressionar as empresas reguladas no sentido de garantir o cumprimento das normas e o atendimento às exigências de qualidade na prestação do serviço. Existem, no entanto, outros instrumentos de pressão, bem como sanções de espécies distintas.

Entre as espécies de sanção podem ser citadas: penal, administrativa retributiva, administrativa ressarcitória, civil, processual etc. Entre outros instrumentos estão, além das próprias sanções, a inclusão de incentivos e desincentivos financeiros atrelados à qualidade do serviço no cálculo das tarifas de remuneração (sinal econômico) e o "constrangimento" via publicação de rankings e outras comparações entre empresas, que têm o efeito de expor a situação da empresa considerada "ruim" a seus clientes, investidores e concorrentes.

No contexto do setor elétrico brasileiro e da atividade da ANEEL, verifica-se a utilização das seguintes ferramentas:

i. sanção administrativa retributiva;

ii. sanção administrativa ressarcitória;

iii. sinal econômico em tarifa;

iv. publicação de ranking de qualidade.

Do ponto de vista econômico se observa que "sinal econômico regulatório em tarifa", "sanção ressarcitória" (compensação) e "sanção retributiva" são institutos distintos e com finalidades específicas. Isso porque o sinal econômico é uma possibilidade de promoção de ganho ou perda com a finalidade de condicionar ações do concessionário; a compensação é um mecanismo pelo qual se substitui uma atividade por outra a fim de satisfazer objetivos frustrados; e a sanção administrativa retributiva está atrelada à infração de norma ou contrato. A publicação de rankings tem um efeito econômico apenas indireto sobre o delegatário do serviço público. 
Do ponto de vista jurídico a sanção retributiva se distingue por sua finalidade disciplinar, repressiva. Segundo Mello (2007),

A sanção administrativa retributiva se destina a imputar um mal ao infrator de acordo com o ato ilícito praticado. [...] A sua finalidade é evitar a repetição de novos atos ilícitos. Tem, assim, caráter repressivo.

A sanção administrativa ressarcitória, por sua vez, objetiva a reparação do dano causado pela empresa ao consumidor. Ainda de acordo com Mello, o ilícito remete à violação do dever geral de não causar danos, nos termos do artigo 186 do Código Civil.

Já a divulgação de rankings e a utilização de sinal econômico na tarifa não tem natureza jurídica de sanção. De acordo a Procuradoria Geral da ANEEL, em seu Parecer no 0697/2011/PGE-ANEEL/PGF/AGU,

Ao passo que a competência da ANEEL para fixar penalidades aos agentes regulados decorre do artigo $3^{\circ}$, X, da Lei $n^{\circ} 9.427 / 1996$, a sua competência para criar sinal econômico regulatório se encontra na combinação do artigo $3^{\circ}$, XIX, com o artigo 14, IV, ambos também da Lei $n^{\circ}$ $9.427 / 1996^{7}$.

Enquanto a publicação de rankings é a exposição de uma comparação entre empresas por meio de indicadores objetivos, as sanções administrativas ressarcitórias e o incentivo/desincentivo financeiro em tarifa guardam relação estreita com o descumprimento de um acordo específico entre o regulador e a empresa regulada, como por exemplo, o atendimento a determinado índice de qualidade na prestação do serviço. Esses instrumentos apresentam, portanto, alto grau de objetividade em seu processo de aplicação.

Já no processo de aplicação das sanções administrativas retributivas, ferramenta própria para garantir o cumprimento de um amplo, complexo e dinâmico conjunto de normas que regem o setor, reside subjetividade e há espaço para o exercício da discricionariedade do regulador.

\footnotetext{
${ }^{7}$ Art. $3^{\circ}[\ldots]$ compete à ANEEL: X - fixar as multas administrativas a serem impostas aos concessionários, permissionários e autorizados de instalações e serviços de energia elétrica [...]; XIX - regular o serviço concedido, permitido e autorizado e fiscalizar permanentemente sua prestação. Art. $14 \mathrm{O}$ regime econômico e financeiro da concessão de serviço público de energia elétrica, conforme estabelecido no respectivo contrato, compreende: [...] IV - IV - apropriação de ganhos de eficiência empresarial e da competitividade.
} 


\section{DISCRICIONARIEDADE}

Este Capítulo discorre sobre o conceito de discricionariedade e sua relação com as ideias de poder normativo e autovinculação da Administração. São apresentados os conceitos de "discricionariedade geral" e "discricionariedade específica", fundamentais para o desenvolvimento do raciocínio sustentado neste estudo.

\subsection{Definiçãa, origem e limites}

É próprio da Administração do Estado de Direito atuar inteiramente segundo os parâmetros da legalidade. No entanto, em face de uma realidade complexa como a tratada pelo direito administrativo, em muitas ocasiões a letra da lei deixa à Administração, no trato do caso concreto, a possibilidade de aplicação de duas ou mais alternativas, todas juridicamente válidas. Nesses casos é que reside a necessidade de exercício da discricionariedade.

A discricionariedade decorre da impossibilidade de o legislador prever, in abstracto, todas as situações possíveis de ocorrerem no mundo real.

Nas palavras de Di Pietro (2007), hoje, a discricionariedade é vista como uma liberdade de opção entre duas ou mais alternativas válidas perante o direito, e não apenas perante a lei.

Ou seja, discricionariedade é a margem de liberdade que resta ao administrador para escolher entre duas ou mais opções de ação. Seu conceito pode ser também entendido como oposto ao do ato vinculado, que é aquele sobre o qual não resta margem de escolha ao administrador.

Para Schirato (2009),

A discricionariedade administrativa poderá decorrer de quatro situações distintas, quais sejam:

(i) conferência expressa pelo comando normativo de discricionariedade; (ii) lacuna da norma jurídica quanto aos critérios de ação do administrador público; (iii) previsão legal expressa de mais de uma ação possível ao administrador no caso concreto; e (iv) existência de conceitos jurídicos indeterminados (i.e., conceitos fluidos, vagos, cuja precisa significação será dada no caso concreto pelo administrador) na hipótese normativa ou na consequência da ocorrência da hipótese, ou em ambas. 
Essa liberdade, no entanto, além de não ser total, pois se subjulga à legalidade, é necessariamente também subordinada ao princípio constitucional da motivação dos atos da Administração. Portanto, as escolhas devem ser feitas e justificadas com base em critérios consistentes.

\subsection{Poder normativo e autovinculação administrativa}

No contexto do direto administrativo brasileiro, para Tavares (2003), Tomando por condição insuperável o princípio da legalidade, já referido, somente pela chamada discricionariedade, isto é, ação no espaço ou no vácuo da norma jurídica, é que se torna possível o exercício de competência normativa concreta pelas agências reguladoras. E surge esse espaço quando, ao descrever a hipótese de incidência (ocorrência material identificada e com referência a tempo, espaço e pessoas), a norma jurídica determina que certas condutas são obrigatórias, proibidas ou permitidas em face do Direito. A agência, para cumprir seu poder de regular, necessariamente, isto é, discricionariamente, terá que qualificar e quantificar, enfim, caracterizar a ocorrência material e a consequente conduta aplicável.

Trata-se de competência regulamentar que somente se exercita na existência de lei, e quando houver espaço deixado pelo legislador (reserva relativa da lei), porque no Brasil, como já se disse, não há regulamento autônomo, nem se admite competência normativa ou regulamentar autônoma das agências; nem do Poder Executivo, como regra.

Portanto, atividade normativa do regulador pode ser vista como exercício de seu poder discricionário. Ela só pode ser admitida quando se verifica a existência de generalidades na lei formal.

No caso da imposição de sanções às empresas que atuam no setor elétrico, fica a cargo de regulamento expedido pela ANEEL o detalhamento das sanções e a tipificação das condutas reprováveis. Mais: não apenas existe espaço na lei formal, como há a determinação expressa do Decreto $n^{\circ} 2.335 / 1997$, contida no $\S 1^{\circ}$ de seu artigo 17 , de que a ANEEL exercite sua competência normativa sobre esse tema.

Art. 17.

$[\ldots]$

$\S 1^{\circ}$ A ANEEL definirá os procedimentos administrativos relativos à aplicação de penalidades, de cobrança e pagamento das multas legais e contratuais, assegurados o contraditório e o direito de ampla defesa.

Em atendimento a essa demanda, a ANEEL publicou a já revogada Resolução Normativa $n^{\circ} 318$, de 06 de outubro de 1998 e, posteriormente, a Resolução Normativa n $^{\circ}$ 63, de 12 de maio de 2004, que definiu 
procedimentos para regular a imposição de penalidades aos concessionários, permissionários, autorizados e demais agentes de instalações e serviços de energia elétrica, bem como às entidades responsáveis pela operação do sistema, pela comercialização de energia elétrica e pela gestão de recursos provenientes de encargos setoriais.

Nesse contexto em que a legislação transfere à ANEEL o poder de determinar a forma específica por meio da qual serão atendidos os interesses públicos previstos de forma genérica, as regras definidas pela Agência Reguladora têm o poder de autovinculação de suas atividades. Essa autovinculação nada mais significa do que uma obrigação do regulador de agir conforme as definições feitas em suas próprias normas.

Para Modesto (2010),

A autovinculação administrativa, em sentido estrito, denota uma hipótese importante de redução da discricionariedade, no âmbito dos atos concretos da Administração Pública, de invocação especialmente útil para impedir atuações caprichosas de agentes públicos ou alterações repentinas no padrão decisório do Poder Público.

É exatamente esse o caso da REN no 63/2004, que descreve, de maneira genérica e abstrata, o procedimento de aplicação de penalidades às empresas do setor ${ }^{8}$.

Por meio da definição de procedimentos em ato normativo de aplicação geral, a ANEEL restringe a discricionariedade a ela conferida pela lei no processo de imposição de sanções administrativas. Assim, sanções impostas em desacordo com as condições previstas na REN nº 63/2004 não podem ser consideradas legalmente válidas.

É importante lembrar que a Agência não é impedida de mudar sua compreensão das situações e o rumo de suas decisões. Pode fazê-lo sempre que devidamente justificado. No entanto, nesses casos, sempre que a conduta modificada é objeto de ato normativo válido, este deve ser também modificado, ou revogado.

Mesmo com a autovinculação decorrente da edição da REN no 63/2004, resta à atividade da Agência, no entanto, um resquício de sua liberdade original: aquela que reside na margem das previsões genéricas feitas em seu próprio ato normativo, e que precisarão ser aplicadas aos casos concretos.

Segundo Marques Neto (2006), o regulamento editado pelo regulador vincula-o, implicando [...] na autolimitação da margem de discricionariedade que antes lhe fora conferida pela Lei.

\footnotetext{
${ }^{8}$ Resoluções Normativas são os atos expedidos pela ANEEL de caráter geral, abstratos e impessoais em relação aos agentes que atuam no setor elétrico brasileiro.
} 


\subsection{Discricionariedades "geral" e "específica"}

No processo de definição de valores de multas, a discricionariedade do regulador é, portanto, exercida em dois níveis: primeiro na margem de liberdade da lei formal, quando no exercício de seu poder normativo, e posteriormente na margem de liberdade de seu próprio regulamento, frente aos casos concretos.

Aqui chamaremos essas duas espécies de "discricionariedade geral" e "discricionariedade específica", pois, de fato, enquanto uma é exercida pela ANEEL de maneira uniforme perante todas as empresas, a outra é intimamente ligada a cada caso tratado.

O primeiro nível - da "discricionariedade geral" - é importante por padronizar procedimentos, definindo padrões mínimos que devem ser seguidos por qualquer que seja a autoridade que aplique penalidade a qualquer empresa. Demonstra uma intenção de autovinculação voluntária da Agência. É importante ainda porque legitima o procedimento junto à sociedade, uma vez que toda norma da ANEEL que afete os direitos dos agentes setoriais ou dos consumidores é discutida, quando de sua edição, em audiência pública ${ }^{9}$ e passa por análise de impacto regulatório ${ }^{10}$.

O segundo nível - da "discricionariedade específica" - é importante por permitir à autoridade que aplica a penalidade ajustar a penalidade ao caso concreto, considerando circunstâncias que não podem ser previstas na norma geral. Seu papel é garantir a adequação da sanção, seu ajustamento aos fins que se pretende alcançar.

Enquanto o exercício da discricionariedade geral presta serviços à isonomia e à segurança jurídica, o uso da discricionariedade específica trabalha pela proporcionalidade e individualização das sanções impostas pela ANEEL. O equilíbrio entre esses dois exercícios é essencial para o estabelecimento de um sistema sancionador eficiente e justo.

Desse modo, os princípios citados não se contradizem ou são excludentes entre si. Ao contrário, convivem em harmonia no sistema. A Administração tem o dever de dar as mesmas soluções a casos essencialmente semelhantes, mas deve, em sua análise, levar em consideração em cada caso, as particularidades da infração e do infrator.

\footnotetext{
${ }^{9}$ A obrigatoriedade de realização de Audiência Pública perviamente à edição de ato normativo que implique "efetiva afetação de direitos dos agentes econômicos do setor elétrico ou dos consumidores" está disposta no art. 28 da Portaria MME n 349/1997, que aprovou o Regimento Interno da ANEEL.

${ }^{10}$ A obrigatoriedade de realização de Análise de Impacto Regulatório previamente à expedição de qualquer ato normativo pela ANEEL está descrita na Resolução Normativa no 540/2013, que aprovou a Norma de Organização no 40 da Agência.
} 


\section{A ANEEL E SUA ESTRUTURA DE FISCALIZAÇÃO}

Este Capítulo mostra a organização dos recursos da ANEEL dedicados à fiscalização e à imposição de sanções administrativas. Descreve as Superintendências de Fiscalização da Agência e explica seu processo de descentralização de atividades a Agências Estaduais conveniadas.

\subsection{As Superintendências de Fiscalização}

A ANEEL foi instituída pela Lei $\mathrm{n}^{\circ}$ 9.427/1996 como autarquia sob regime especial vinculada ao Ministério de Minas e Energia, com finalidade de regular e fiscalizar produção, transmissão, distribuição e comercialização de energia elétrica, de acordo com a legislação específica e em conformidade com as diretrizes do governo federal.

O Regimento Interno da Agência, aprovado pela Portaria MME no 349/1997, estabeleceu em sua estrutura três unidades organizacionais dedicadas a atividades de fiscalização, são elas:

Superintendência de Fiscalização dos Serviços de Geração - SFG, com atribuições de controle e fiscalização: dos serviços e instalações de geração de energia elétrica, desde a implantação ou ampliação até a sua operação; de agentes de operação de sistemas e de comercialização de energia no setor elétrico, em conjunto com as demais áreas de fiscalização da ANEEL; de encargos setoriais e programas de governo afetos aos agentes de geração; e do cumprimento das obrigações constantes dos contratos de concessão e de autorizações de geração (art. 23, IX);

Superintendência de Fiscalização dos Serviços de Eletricidade - SFE, com atribuições de

controle e fiscalização: dos serviços e instalações de transmissão de energia elétrica, incluindo a de agentes de operação de sistemas e a análise de perturbações relevantes no sistema elétrico; do cumprimento das obrigações constantes dos contratos de concessão e permissão de distribuição, especialmente quanto à qualidade dos serviços técnicos e comerciais; de programas de governo afetos aos agentes de transmissão e distribuição; e de laudos de avaliação de ativos imobilizados em serviço (art. 23, X);

Superintendência de Fiscalização Econômica e Financeira - SFF, com atribuições de controle e fiscalização econômico-financeira e contábil das concessões, permissões e autorizações dos serviços e instalações de energia elétrica, incluindo a gestão dos fundos 
setoriais, bem como de operações comerciais e societárias sujeitas a controle prévio ou a posteriori; desenvolvimento de ações de caráter preventivo e corretivo para preservar o equilíbrio econômico-financeiro das concessões e permissões; e padronização de procedimentos contábeis a serem observados pelos agentes regulados (art. 23, XI).

A figura a seguir ilustra as áreas de atuação das três Superintendências de Fiscalização da ANEEL:

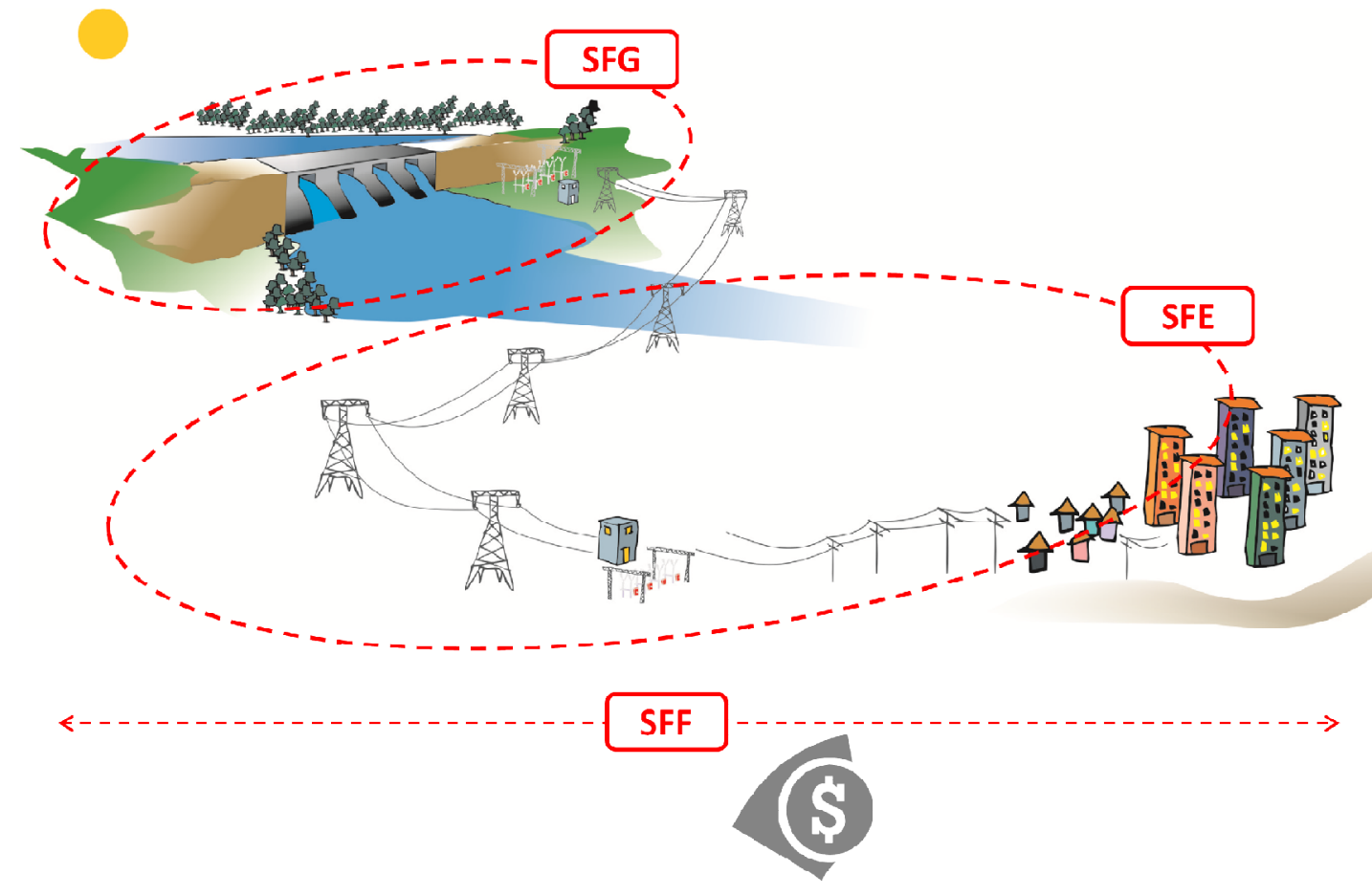

Figura 5.1 - Atuação das Superintendências de Fiscalização da ANEEL

Fonte: SFG, figura constante de apresentação feita pela Superintendência em 26/09/2013: "Fiscalização dos Serviços de Geração de Energia Elétrica no Brasil”

Essas Superintendências vinculam-se diretamente à Diretoria e a ela servem como base de apoio e instruções em suas deliberações, no âmbito do Processo Organizacional "Fiscalização dos Serviços e Instalações de Energia Elétrica" (art. $3^{\circ}, \S$ único e art. 5º V da Portaria MME no 349/1997).

À Diretoria, formada por um Diretor Geral e mais quatro Diretores, cabe analisar, discutir e decidir, em instância administrativa final, as matérias relacionadas com as competências da ANEEL (art. $7^{\circ}$ ), entre elas os processos administrativos punitivos instaurados pelas Superintendências de Fiscalização. 
As decisões da Diretoria são tomadas em regime colegiado. Os processos são sorteados para que sejam relatados por um diretor, que expõe seu voto (proposta de decisão) por meio de relatório. Sobre essa proposta é feita a discussão e a votação dos demais diretores.

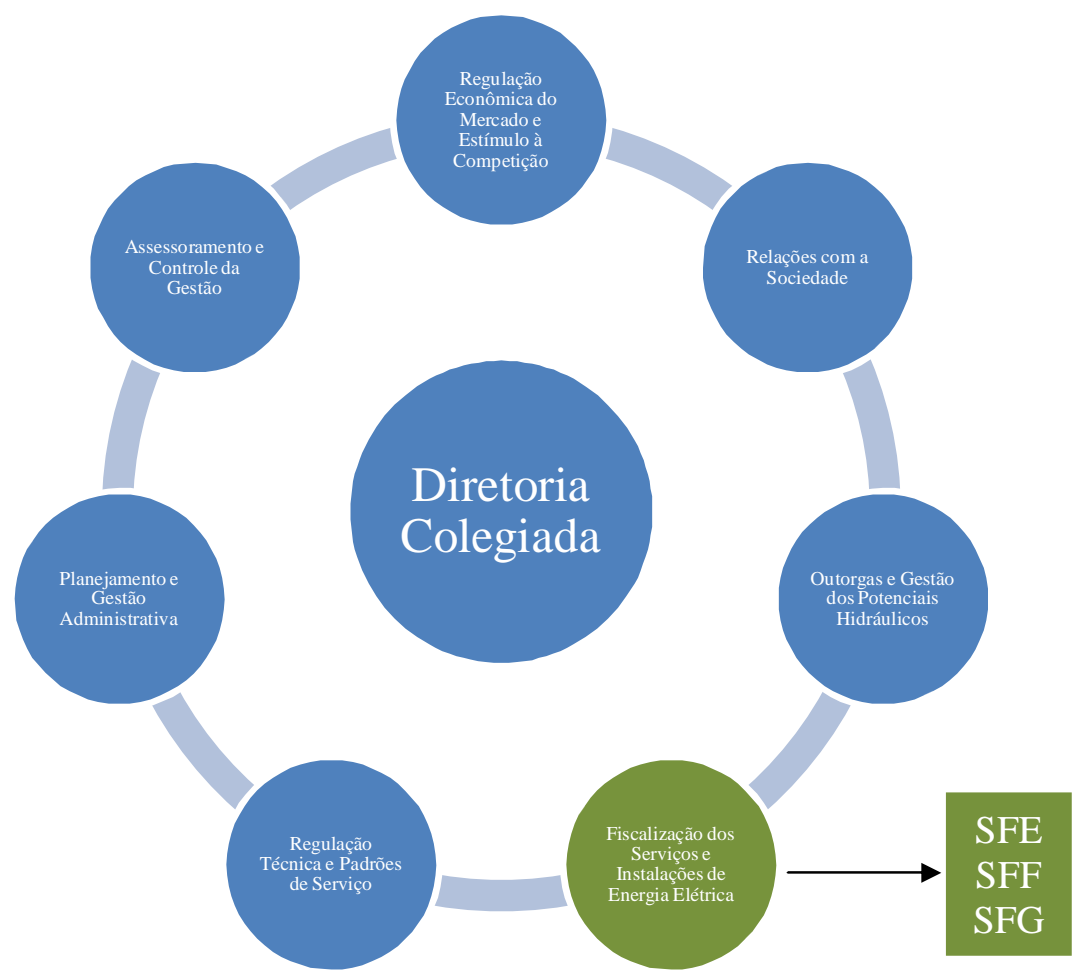

Figura 5.2 - Diretoria Colegiada e processos organizacionais na ANEEL

Fonte: Elaboração própria

Desse modo, as sanções impostas são percebidas pelas empresas do setor em dois momentos: a sanção original exarada pela Superintendência de Fiscalização e, após o curso do processo administrativo, a sanção final julgada pela Diretoria ${ }^{11}$.

\footnotetext{
${ }^{11}$ É claro que nos casos em que a empresa autuada não interpõe recurso frente à decisão da Superintendência de Fiscalização, a sanção é por ela percebida uma única vez. A percepção em dois momentos se refere aos processos que são levados até a última instância administrativa, a Diretoria da ANEEL.
} 


\subsection{Descentralização de atividades}

Um aspecto relevante sobre a maneira de atuar das áreas de fiscalização da ANEEL diz respeito à descentralização de parte de suas atividades a Agências Reguladoras Estaduais conveniadas. De acordo com o artigo 20 da Lei no 9.427/1996,

a execução das atividades complementares de regulação, controle e fiscalização dos serviços e instalações de energia elétrica poderá ser descentralizada pela União para os Estados e para o Distrito Federal visando à gestão associada de serviços públicos, mediante convênio de cooperação.

A Resolução Normativa nº 417/2010 definiu condições para o estabelecimento desse tipo de parceria:

Art. 39. O Convênio de Cooperação somente é celebrado com a comprovação das condições discriminadas a seguir:

I - constituição, por parte do Estado-membro, de AGÊNCIA com lei de criação; lei ou decreto de regulamentação, quando houver; e regimento interno promulgados e publicados, os quais disporão necessariamente sobre a:

a) competência para a execução, sob delegação, de serviços públicos da União;

b) autonomia administrativa, financeira, decisória e patrimonial;

c) nomeação de dirigentes pelo chefe do Estado-membro, após aprovação pela Assembleia Legislativa ou Câmara Legislativa, para cumprir mandatos fixos e, preferencialmente, não coincidentes;

d) existência de órgão colegiado de deliberação máxima com, no mínimo, três membros não impedidos de atuar em processos administrativos do setor de energia elétrica, conforme art. 18, da Lei 9.784, de 29 de janeiro de 1999; e

e) existência de, no máximo, duas instâncias recursais administrativas, com vistas a atender ao disposto no art. 57, da Lei 9.784, de 1999, e à legislação federal que estabelece a ANEEL como instância máxima nos processos administrativos sobre energia elétrica.

II - estruturação, por parte do Estado-membro, de AGÊNCIA com:

a) corpo técnico administrativo para exercer as atividades da área-meio, e instalações físicas adequadas para a execução das atividades descentralizadas; e

b) Comissão de Ética criada nos moldes do inciso XVI, do Decreto 1.171, de 1994, e suas alterações.

Essa é uma realidade dinâmica, que pode variar conforme o interesse e a oportunidade da ANEEL e dos Estados, a disponibilidade de recursos e o atendimento de condições específicas. No ano de 2013 a ANEEL tem convênio firmado com 12 Agências Estaduais, que executam, além de outros serviços, uma parte das atividades de fiscalização e de imposição de sanções nos Estados de Santa Catarina, Rio Grande do Sul, São Paulo, Mato Grosso, Mato Groso do Sul, Goiás, Alagoas, Pernambuco, Paraíba, Rio Grande do Norte, Ceará e Pará. Há 
ainda acordos de interesse firmados com as Agências de Tocantins, Espírito Santo e Acre, que podem vir a executar atividades de competência da ANEEL no futuro próximo. Outras Agências estaduais já tiveram parcerias válidas com a ANEEL no passado, mas que hoje não estão mais em andamento, como é o caso das Agências da Bahia e do próprio Tocantins.

A Figura 5.3, a seguir, ilustram a situação atual.

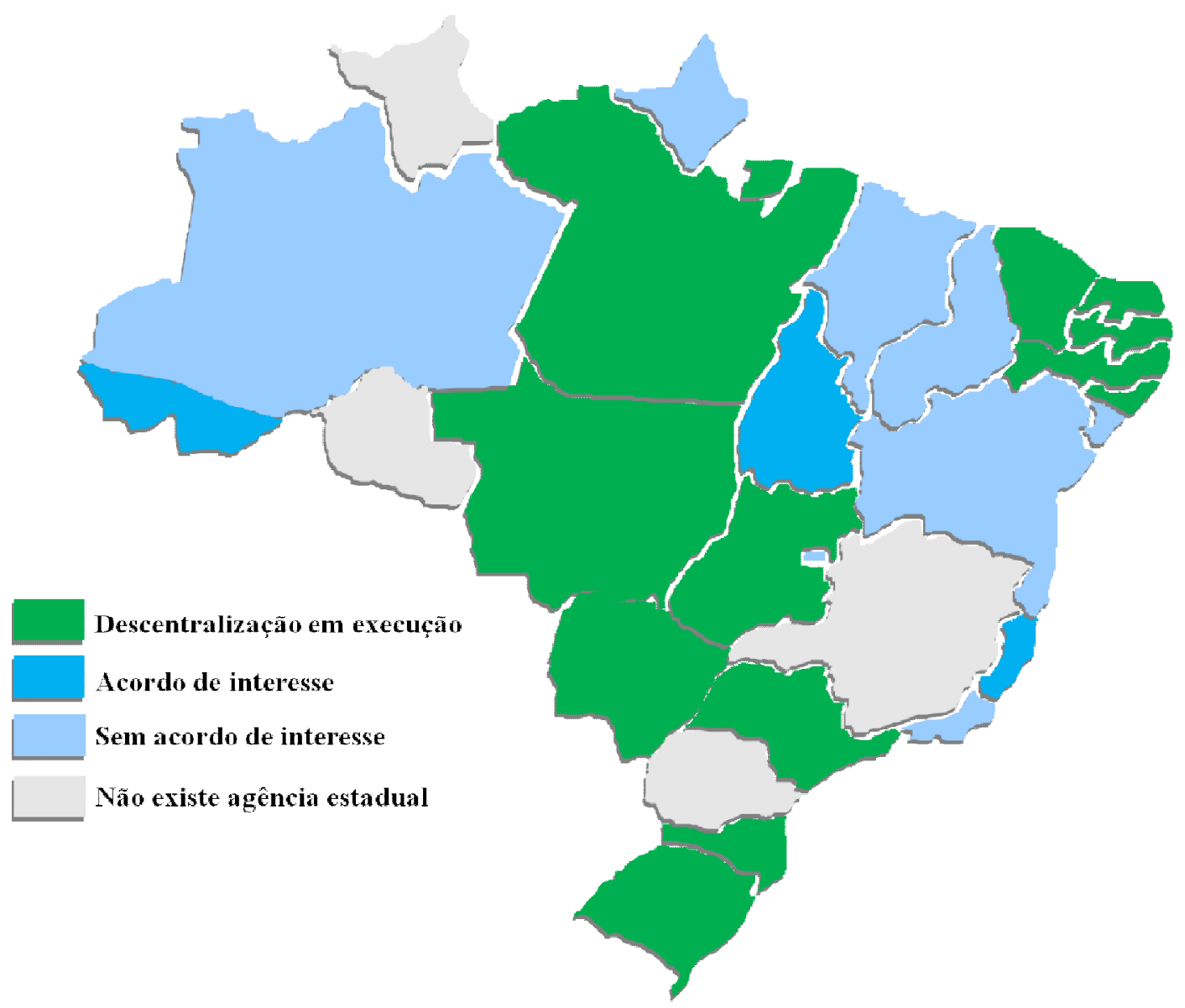

Figura 5.3 - Mapa da descentralização de atividades da ANEEL

Fonte: Elaboração própria com dados do sítio da ANEEL na internet

A Tabela 5.1, a seguir, relaciona as Agências Reguladoras Estaduais brasileiras. 
Tabela 5.1 - Agências Reguladoras Estaduais

Fonte: Elaboração própria com dados do sítio da ANEEL na internet

\begin{tabular}{|c|c|c|}
\hline $\mathbf{U F}$ & Agência & Nome Completo \\
\hline $\mathrm{DF}$ & ADASA & Agência Reguladora de Águas, Energia e Saneamento do Distrito Federal \\
\hline $\mathrm{AC}$ & AGEAC & Agência Reguladora dos Serviços Públicos do Estado do Acre \\
\hline $\mathrm{AM}$ & ARSAM & Agência Reguladora dos Serviços Públicos Concedidos do Estado do Amazonas \\
\hline PA & ARCON & Agência de Regulação e Controle de Serviços Públicos do Estado do Pará \\
\hline $\mathrm{AP}$ & ARSAP & Agencia Reguladora de Serviços Delegado do Estado do Amapá \\
\hline MA & ARSEMA & Agência Reguladora de Serviços Públicos do Maranhão \\
\hline PI & AGRESPI & Agência de Regulação dos Serviços Públicos Delegados do Estado do Piauí \\
\hline $\mathrm{CE}$ & ARCE & Agência Reguladora de Serviços Públicos Delegados do Estado do Ceará \\
\hline RN & ARSEP & Agência Reguladora de Serviços Públicos do Rio Grande do Norte \\
\hline PB & ARPB & Agência de Regulação do Estado da Paraíba \\
\hline $\mathrm{PE}$ & ARPE & Agência de Regulação dos Serviços Públicos Delegados do Estado de Pernambuco \\
\hline $\mathrm{AL}$ & ARSAL & Agência Reguladora de Serviços Públicos do Estado de Alagoas \\
\hline MT & AGER & Agência de Regulação dos Serviços Públicos Delegados do Estado de Mato Grosso \\
\hline $\mathrm{TO}$ & ATR & Agência Tocantinense de Regulação, Controle e Fiscalização dos Serviços Públicos \\
\hline BA & AGERBA & Agência Estadual de Regulação de Serviços Públicos de Energia, Transporte e Comunicação da Bahia \\
\hline $\mathrm{GO}$ & AGR & Agência Goiana de Regulação, Controle e Fiscalização de Serviços Públicos \\
\hline MS & AGEPAN & Agência Estadual de Regulação de Serviços Públicos do Mato Grosso do Sul \\
\hline SP & ARSESP & Agência Reguladora de Saneamento e Energia do Estado de São Paulo \\
\hline ES & ASPE & Agência de Serviços Públicos de Energia do Estado do Espírito Santo \\
\hline RJ & AGENERSA & Agência Reguladora de Energia e Saneamento Básico do Estado do Rio de Janeiro \\
\hline $\mathrm{SC}$ & AGESC & Agência Reguladora de Serviços Públicos de Santa Catarina \\
\hline RS & AGERGS & Agência Estadual de Regulação dos Serviços Públicos Delegados do Rio Grande do Sul \\
\hline
\end{tabular}

Uma vez existente o convênio, cabe a cada Superintendência da ANEEL celebrar contrato de metas com as Agências Estaduais, também conforme a oportunidade e a conveniência de descentralizar suas atividades nesses estados, e a possibilidade técnica das Agências em executá-las.

A Tabela 5.2 representa a relação de contratos de metas firmados no ano de 2013 entre as Agências Estaduais e as Superintendências de Fiscalização da ANEEL.

Tabela 5.2 - Descentralização de atividades em cada Superintendência de Fiscalização da ANEEL em 2013 Fonte: Elaboração própria com dados do sítio da ANEEL na internet

\begin{tabular}{c|c|c|c|c|c|c|c|c|c|c|c|c}
\hline & ARCON & ARCE & ARSEP & ARPB & ARPE & ARSAL & AGER & AGR & AGEPAN & ARSESP & AGESC & AGERGS \\
\hline SFE & $\sqrt{ }$ & $\sqrt{ }$ & & $\sqrt{ }$ & $\sqrt{ }$ & $\sqrt{ }$ & $\sqrt{ }$ & $\sqrt{ }$ & $\sqrt{ }$ & $\sqrt{ }$ & & $\sqrt{ }$ \\
\hline SFF & & & & & & & & & & $\sqrt{ }$ & $\sqrt{ }$ & $\sqrt{ }$ \\
\hline SFG & $\sqrt{ }$ & $\sqrt{ }$ & $\sqrt{ }$ & & $\sqrt{ }$ & & $\sqrt{ }$ & $\sqrt{ }$ & $\sqrt{ }$ & $\sqrt{ }$ & $\sqrt{ }$ & $\sqrt{ }$ \\
\hline
\end{tabular}


Cabe esclarecer que, nos processos punitivos instaurados pelas Agências Estaduais, a decisão em instância administrativa final é de competência da Diretoria da ANELL (art. 39, I da REN no 417/2010). Ou seja, as empresas autuadas pelas Agências Estaduais têm direito a interpor recurso que, se não for integralmente acatado pela própria Agência, é endereçado à Diretoria da ANEEL. 


\section{A ATUAL REGULAMENTAÇÃO: A RESOLUÇÃO NORMATIVA No $63 / 2004$}

Este Capítulo tem por objetivo apresentar a REN nº 63/2004, que em maio de 2014 completa 10 anos de vigência. Ela consiste no segundo esforço da ANEEL, em termos de regulamentação, para disciplinar o processo de aplicação de penalidades. Sua publicação revogou a Resolução Normativa $n^{\circ}$ 318, de 06 de outubro de 1998, que tratou do tema anteriormente.

Desde sua edição, a REN n 63/2004 sofreu diversas alterações, realizadas por meio da publicação de normas posteriores ${ }^{12}$. A estrutura atual do documento consiste de dois títulos principais: "Das penalidades" e "Dos procedimentos", além "Das disposições finais".

À época de sua publicação, o texto da resolução não foi objeto de audiência pública, instrumento que hoje sistematiza a participação da sociedade na construção de normas da ANEEL.

O caput da norma deixa clara sua função:

Aprova procedimentos para regular a imposição de penalidades aos concessionários, permissionários, autorizados e demais agentes de instalações e serviços de energia elétrica, bem como às entidades responsáveis pela operação do sistema, pela comercialização de energia elétrica e pela gestão de recursos provenientes de encargos setoriais.

A íntegra da Resolução, conforme seu texto em novembro de 2013, compõe o ANEXO A deste estudo.

\subsection{As infrações e as penalidades}

$\mathrm{O}$ artigo $2^{\circ}$ da Resolução descreve seis diferentes tipos de penalidades passíveis de serem aplicadas pela Agência. Os artigos $3^{\circ}$ a 13 apontam as infrações correspondentes a cada uma delas. A Tabela 6.1, a seguir, mostra a quantidade de infrações relacionadas a cada tipo de penalidade.

\footnotetext{
12 A REN no 63/2004 teve seu texto modificado pelas seguintes normas expedidas pela ANEEL: REN $n^{\circ}$

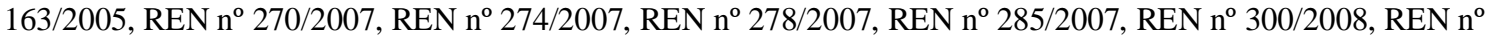
314/2008, REN no 316/2008, REN no 317/2008, REN no 333/2008, REN n $334 / 2008$, REN n $n^{\circ} 350 / 2009$, REN n 393/2009, REN no 427/2011, REN n ${ }^{\circ} 470 / 2011, \operatorname{REN~n}^{\circ} 479 / 2012, \operatorname{REN~n}^{\circ}$ 500/2012, REN n ${ }^{\circ} 545 / 2013, \mathrm{REN} \mathrm{n}^{\circ}$ $560 / 2013$ e $\operatorname{REN~n}^{\circ} 581 / 2013$.
} 
Tabela 6.1 - Infrações tipificadas na REN 63/2004

Fonte: Elaboração própria

\begin{tabular}{c|c}
\hline Penalidade & Quantidade de infrações tipificadas $^{\mathbf{1 3}}$ \\
\hline Advertência & 14 \\
\hline Multa & 87 \\
\hline Embargo de obras ou interdição de instalações & 1 \\
\hline Suspensão temporária de participação em licitações & 5 \\
\hline $\begin{array}{c}\text { Revogação de autorização ou caducidade da concessão ou da } \\
\text { permissão }\end{array}$ & 15 \\
\hline Intervenção administrativa & 8 \\
\hline Total & $\mathbf{1 3 0}$ \\
\hline
\end{tabular}

Cabe observar que o artigo $8^{\circ}$ prevê a possibilidade de converter em advertência as penalidades originalmente descritas como multa, desde que a infratora não tenha sido autuada por idêntica infração nos últimos quatro anos anteriores ao da sua ocorrência, uma verificação objetiva, e as consequências da infração sejam de pequeno potencial ofensivo, uma conceituação subjetiva a cargo do órgão regulador.

Uma característica da norma é o detalhamento com que são descritas as condutas qualificadas como infrações (ver ANEXO A). Esse detalhamento faz com que seja necessária a descrição de uma grande quantidade delas (130).

Entre as condutas que são qualificadas como infrações, 87 são passíveis de penalidade de multa. Esse número é um indicativo da importância desse tipo de sanção na atuação da ANEEL. Este indicativo é, de fato, corroborado pelos números apresentados no Capítulo 8.

\subsection{O valor máximo das multas}

No artigo 14 da REN nº 63/2004 são elencados os valores máximos das penalidades, em relação ao faturamento da empresa apenada nos 12 meses anteriores à lavratura do auto de infração $^{14}$. As 87 infrações passíveis de penalidade de multa descritas na Tabela 6.1 são divididas em quatro grupos.

\footnotetext{
${ }^{13} \mathrm{O}$ cômputo das infrações foi baseado na quantidade de incisos ou artigos que descrevem condutas passíveis de penalização.

${ }^{14} \mathrm{O}$ artigo 14 da REN no 63/2004 esclarece que o que se entende por "faturamento" é o valor das receitas oriundas da venda de energia elétrica e prestação de serviços, deduzidos o ICMS e o ISS. Explica também os critérios para estimação desse valor nos casos em que a empresa autuada atua como autoprodutora ou produtora independente de energia elétrica ou se trata de "entidades responsáveis pela operação do sistema, pela câmara de comercialização de energia elétrica e pela gestão dos recursos provenientes de encargos setoriais". O mesmo artigo também estabelece que o faturamento estimado é utilizado nos casos em que o empreendimento por meio
} 
Tabela 6.2 - Grupos de penalidades na REN n 63/2004

Fonte: Elaboração própria

\begin{tabular}{c|c|c}
\hline Grupo & \% do faturamento nos últimos 12 meses & Quantidade de infrações tipificadas \\
\hline I & Até $0,01 \%$ (um centésimo por cento) & 19 \\
\hline II & Até 0,10\% (dez centésimos por cento) & 19 \\
\hline III & Até 1\% (um por cento) & 23 \\
\hline IV & Até 2\% (dois por cento) & 26 \\
\hline \multicolumn{2}{r}{ Total } & $\mathbf{8 7}$ \\
\hline
\end{tabular}

Essa divisão mostra que a Agência estabelece claramente uma hierarquia entre as infrações, de acordo com sua nocividade ao mercado que lhe cabe regular. O valor máximo para uma multa do Grupo IV é 200 vezes maior que o valor máximo de uma multa do Grupo I, considerando-se a mesma base de cálculo, ou seja, o mesmo faturamento. A Figura 6.1 ilustra essa relação ${ }^{15}$.

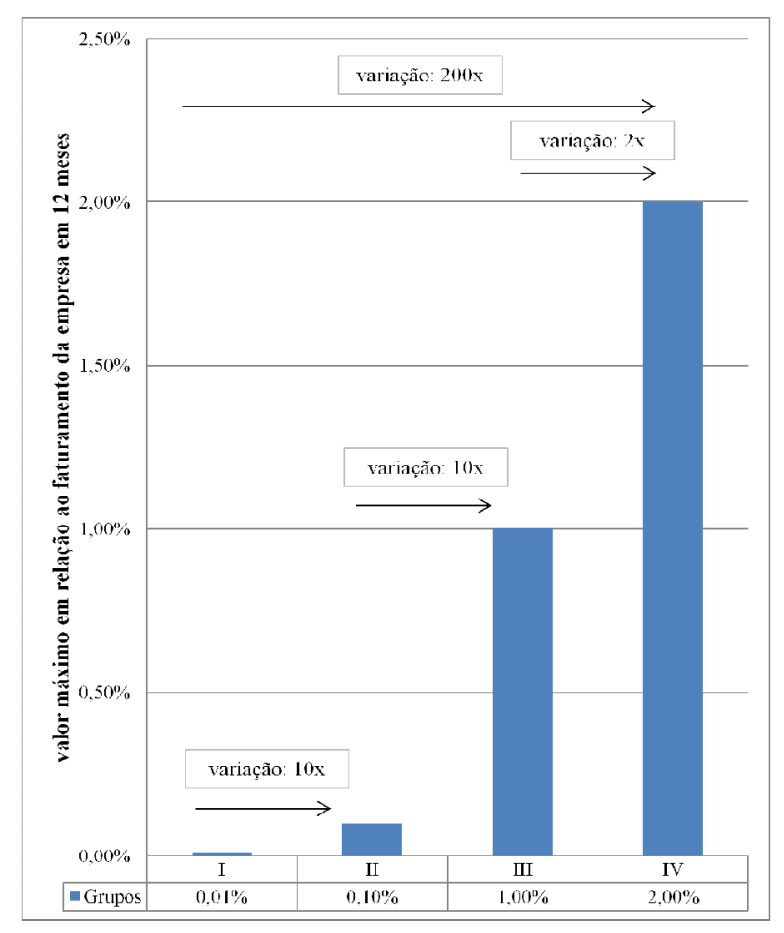

Figura 6.1 - Os grupos de multas previstos na REN no 63/2004

Fonte: Elaboração própria

do qual a empresa cometeu a infração não tenha iniciado sua operação, ou essa operação tenha se iniciado há menos de doze meses.

${ }^{15}$ Cabe esclarecer que todos os percentuais sobre os quais se discute são definidos para uma infração cometida pela empresa autuada (art. $3^{\circ}, \mathrm{X}$ da Lei $\mathrm{n}^{\circ}$ 9.427/1996), mas a ANEEL pode aplicar (e frequentemente aplica) várias penalidades em um único auto de infração, conforme o resultado da fiscalização realizada. Desse modo, as empresas do setor elétrico podem sofrer, de uma só vez, penalidades de multa que excedam, em sua soma, até mesmo o limite de $2 \%$ de seu faturamento anual. 
O estabelecimento do valor das multas com base em uma proporção do faturamento da empresa apenada guarda relação com os princípios da eficácia e da razoabilidade. Se o valor for "muito pequeno" para a empresa, obviamente não fará diferença para essa ser ou não apenada, ficando prejudicada a finalidade preventiva da sanção. Por outro lado, se o valor for "muito grande" para a empresa, corre-se o risco de prejudicar demasiadamente sua saúde financeira e, consequentemente, a prestação do serviço.

\subsection{Os critérios para estabelecimento do valor das multas}

O artigo 15 da REN no 63/2004 lista os critérios que devem ser considerados no estabelecimento do valor das multas:

a abrangência e a gravidade da infração, os danos dela resultantes para o serviço e para os

usuários, a vantagem auferida pela infratora e a existência de sanção administrativa irrecorrível, nos últimos quatro anos.

O artigo 16 provê a forma como a Agência deve proceder em caso de reincidência da empresa no mesmo tipo de infração: transformar em multa do Grupo I as penalidades antes definidas como advertências e majorar em 50\% o valor das penalidades originalmente definidas como multas.

Cabe observar que, com exceção do critério de reincidência, para o qual é definido um método objetivo de aplicação, a norma não estipula propriamente uma dosimetria para aplicação de multas, apontando apenas os critérios que devem ser considerados. O "peso" dado a cada um desses critérios no valor final das multas e a maneira como cada um é considerado no cálculo ficam sujeitos a um alto grau de discricionariedade por parte da autoridade que aplica a penalidade. A maneira como as áreas de fiscalização da ANEEL vêm exercendo essa discricionariedade é delineada no Capítulo 7 deste estudo.

\subsection{Os procedimentos de fiscalização e de aplicação de penalidades}

O Título II da REN nº 63/2004, que compreende os artigos de número 18 a 35-G, estabelece o rito processual que deve ser seguido desde a notificação da empresa sobre a fiscalização realizada até o pagamento de eventual multa, passando pela instrução do auto de infração ou do termo de intimação e pela apreciação das manifestações da empresa. $\mathrm{O}$ fluxograma que segue descreve simplificadamente esse rito. 


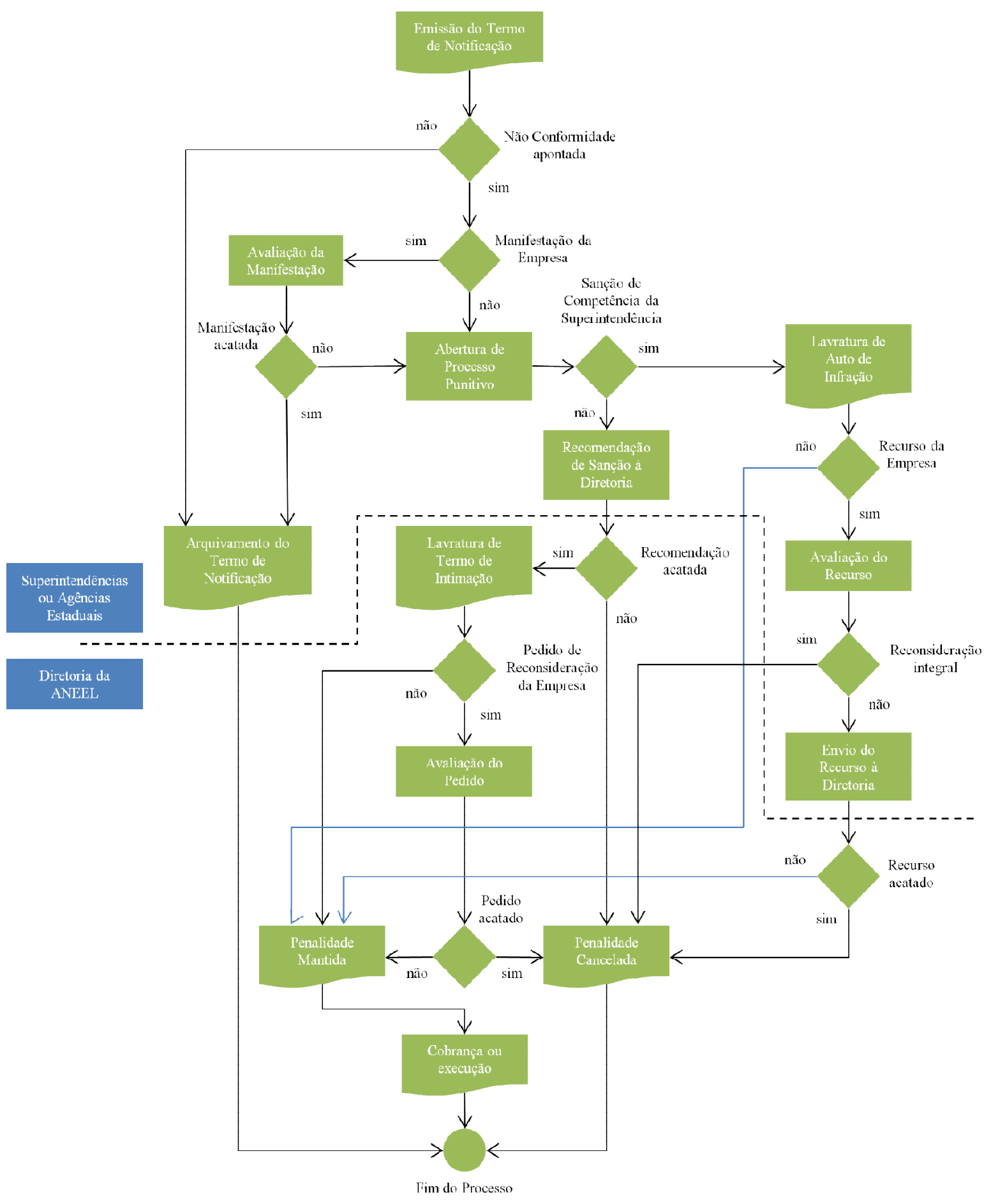

Figura 6.2 - O rito descrito na REN n ${ }^{0}$ 63/2004

Fonte: Elaboração própria 
O resultado da ação de fiscalização é informado à empresa por um Termo de Notificação, que contém constatações e, eventualmente, não conformidades, determinações e recomendações. Sempre que apontadas não conformidades, a empresa é instada a se manifestar e, se não conseguir descaracterizá-las, é instaurado processo punitivo. No caso contrário, o Termo de Notificação é arquivado.

Nos casos em que a punição pretendida é de competência da Diretoria (revogação de autorização, caducidade de concessão ou permissão e intervenção administrativa), a unidade organizacional responsável pela fiscalização a ela recomenda a emissão de Termo de Intimação. Do contrário (advertência, multa, embargo de obras e interdição de instalações), a própria unidade emite um Auto de Infração. Em ambos os casos a empresa tem direito à interposição de recurso, e a instância administrativa final é sempre a Diretoria.

Cabe observar que o rito descrito pela norma não compreende todo o processo de fiscalização, mas apenas sua fase posterior à emissão do Termo de Notificação. Não detalha também o processo de estabelecimento da dosimetria das sanções aplicadas às empresas. 


\section{A COMPREENSÃO E A APLICAÇÃO DA REN No 63/2004 NA DOSIMETRIA DE MULTAS}

Considerando o nível de discricionariedade deixado pelo texto da REN 63/2004 às autoridades competentes para instaurar e conduzir processos punitivos (discricionariedade específica), as Superintendências de Fiscalização da ANEEL buscaram, cada uma a seu modo, definir os parâmetros de dosimetria para as sanções que aplicam.

Este Capítulo expõe as regras elaboradas por SFE (responsável pelos segmentos de transmissão e distribuição), SFF (responsável pelo acompanhamento da situação econômicofinanceira) e SFG (responsável pelo segmento de geração) como tentativa de uniformizar seu exercício da discricionariedade específica em processos punitivos semelhantes. Elucida também a conduta das Agências Estaduais e da Diretoria da ANEEL nesse âmbito.

Cumpre destacar que são citadas todas as regras ou práticas "mais ou menos estabelecidas" que puderam ser identificadas, o que não exclui a possibilidade de existência de outras. Ainda, uma vez que essas regras não estão definidas em atos oficiais (Resolução, Portaria, Despacho etc.), não existe garantia de que sejam cumpridas estritamente, de modo que adaptações podem ser feitas em casos específicos.

\subsection{A prática da Superintendência de Fiscalização dos Serviços de Eletricidade - SFE}

A SFE elaborou a Nota Técnica $n^{\circ}$ 39/2010-SFE/ANEEL, na qual desenvolveu a seguinte fórmula para definição do valor de multas:

$$
M=(0,5 * G+0,2 * D+0,2 * V+0,1 * S) * A * \text { MaxGrupo } * r * \text { Fat }
$$

Onde:

M - multa, em reais;

$\mathrm{G}$ - gravidade (\%);

D - danos resultantes para o serviço e para os usuários (\%);

$\mathrm{V}$ - vantagem auferida pela empresa com a infração (\%);

$\mathrm{S}$ - existência de sanções nos últimos quatro anos (\%);

$A$ - abrangência (\%);

$r$ - reincidência $(r=1$ ou $r=1,5)$; 
MaxGrupo - valor máximo do respectivo grupo (\%);

Fat - faturamento da empresa nos últimos 12 meses, em reais.

Quanto ao parâmetro "reincidência" (r) a Superintendência seguiu o descrito na REN 63/2004 e definiu seu valor em "1" para o caso de não se tratar de infração reincidente, e "1,5" no caso contrário. Já para as "sanções irrecorríveis nos últimos quatro anos" (S), foi definida a regra descrita na Tabela 7.1, a seguir:

Tabela 7.1 - Critério da SFE para sanções irrecorríveis

Fonte: Nota Técnica nº 39/2010-SFE/ANEEL

\begin{tabular}{c|c|c|c|c|c|c}
\hline Número de sanções & $\mathbf{0} \rightarrow \mathbf{4}$ & $\mathbf{5} \rightarrow \mathbf{8}$ & $\mathbf{9} \rightarrow \mathbf{1 2}$ & $\mathbf{1 3} \rightarrow \mathbf{1 6}$ & $\mathbf{1 7} \rightarrow \mathbf{2 0}$ & Acima de 20 \\
\hline Percentual & $10 \%$ & $20 \%$ & $40 \%$ & $60 \%$ & $80 \%$ & $100 \%$ \\
\hline
\end{tabular}

A condicionante "abrangência" (A) é utilizada pela SFE no sentido estrito do termo, ou seja, como sendo

a relação entre a quantidade de itens não conformes da amostra objeto da fiscalização e a quantidade total de itens dessa amostra, ou a partir da avaliação da quantidade de consumidores afetados pela irregularidade em relação ao total de consumidores de um dado universo. (Nota Técnica nº 39/2010-SFE/ANEEL)

Apesar dessas regras que amoldam o exercício da discricionariedade da SFE em vários parâmetros importantes para o estabelecimento dos valores das multas, a definição dos parâmetros "gravidade", "danos" e "vantagens" é feita caso a caso de maneira subjetiva, conforme este trecho da citada Nota Técnica:

os percentuais correspondentes às condicionantes: Gravidade (G), Danos (D) e Vantagem (V) são estabelecidos por esta Superintendência com base no convencimento motivado, em função das evidências objetivas documentadas de cada não conformidade, expressando uma avaliação qualitativa de quão grave é a irregularidade cometida, quando da elaboração da Exposição de Motivos para Auto de Infração. (Nota Técnica n 39/2010-SFE/ANEEL)

As regras aqui expostas parecem ser aplicadas pela SFE na maioria dos autos de infração que lavra contra as empresas que cometem infrações em suas atividades nos segmentos de transmissão e distribuição de energia elétrica, porém não se exclui a possibilidade de outros métodos, não definidos e padronizados, serem utilizados em casos específicos. 


\subsection{A prática da Superintendência de Fiscalização Econômica e Financeira - SFF}

Por meio da Nota Técnica $n^{\circ}$ 384/2012-SFF/ANEEL, a SFF definiu a metodologia para quantificação das sanções referentes a uma família específica de infrações, as geradas pela inadimplência ou pela inconsistência no envio à ANEEL, por parte das empresas reguladas, de informações econômico-financeiras requeridas pela regulamentação.

Para essas infrações a Superintendência desenvolveu uma sistemática bastante precisa, que conta com a aplicação de pisos e tetos, com a intenção de evitar multas irrisórias ou exorbitantes.

Quanto aos critérios descritos na REN no 63/2004, o único utilizado pela Superintendência para a quantificação de sanções dessa natureza é a "gravidade" da infração. Essa escolha é justificada pela SFF na nota técnica citada, em que defende que, além de critérios como "danos", "vantagens" e "abrangência" não fazerem sentido para esse tipo de infração, a consideração unicamente da gravidade já bastaria para cumprir com o objetivo de definir as sanções adequadamente.

Essa metodologia da SFF pode ser resumida nas duas tabelas que seguem, uma referente às sanções por inadimplência, e a outra às sanções por inconsistência no envio de informações econômico-financeiras.

Tabela 7.2 - Critério da SFF para inadimplência em envio de informações

Fonte: Elaboração própria com dados da Nota Técnica no 384/2012-SFF/ANEEL

\begin{tabular}{c|c|c|c|c}
\hline Grau de gravidade & $\begin{array}{c}\text { Envio em atraso } \\
\text { menor ou igual a } \\
\mathbf{1 0} \text { dias }\end{array}$ & $\begin{array}{c}\text { Envio antes } \\
\text { da emissão } \\
\text { do TN }\end{array}$ & $\begin{array}{c}\text { Envio após emissão } \\
\text { do TN e no prazo } \\
\text { nele estabelecido }\end{array}$ & $\begin{array}{c}\text { Envio após emissão do } \\
\text { TN e em fora do prazo } \\
\text { nele estabelecido }\end{array}$ \\
\hline $\begin{array}{c}\text { Penalidade e multa } \\
(\% \text { sobre o } \\
\text { faturamento anual) }\end{array}$ & Advertência & $0,001 \%$ & $0,005 \%$ & $0,02 \%$ \\
\hline Piso (R\$) & 0 & 2.000 & 2.000 & 2.000 \\
\hline Teto (R\$) & 0 & 20.000 & 100.000 & 400.000 \\
\hline
\end{tabular}


Tabela 7.3 - Critério da SFF para inconsistência em envio de informações

Fonte: Elaboração própria com dados da Nota Técnica n 384/2012-SFF/ANEEL

\begin{tabular}{c|c|c|c|c|c|c|c}
\hline Grau de gravidade & $\mathbf{i}<=\mathbf{1 0} \mathbf{~ n g}$ & $\begin{array}{c}\mathbf{i}<=10 \mathbf{e} \\
\mathbf{0}<\mathbf{g}<=\mathbf{2}\end{array}$ & $\begin{array}{c}\mathbf{i}>\mathbf{1 0} \mathbf{e} \\
\mathbf{0}<\mathbf{g}<=\mathbf{2}\end{array}$ & $\begin{array}{c}\mathbf{i}<=\mathbf{1 0} \mathbf{e} \\
\mathbf{3}<\mathbf{g}<=\mathbf{5}\end{array}$ & $\begin{array}{c}\mathbf{i}>\mathbf{1 0} \mathbf{e} \\
\mathbf{3}<\mathbf{g}<=\mathbf{5}\end{array}$ & $\begin{array}{c}\mathbf{i}<=\mathbf{1 0} \mathbf{e} \\
\mathbf{g}>\mathbf{5}\end{array}$ & $\begin{array}{c}\mathbf{i}>\mathbf{1 0} \mathbf{e} \\
\mathbf{g}>\mathbf{5}\end{array}$ \\
\hline $\begin{array}{c}\text { Penalidade e multa (\% } \\
\text { sobre o faturamento } \\
\text { anual) }\end{array}$ & Advertência & $0,002 \%$ & $0,003 \%$ & $0,005 \%$ & $0,007 \%$ & $0,010 \%$ & $0,012 \%$ \\
\hline Piso (R\$) & 0 & 2.000 & 2.000 & 2.000 & 2.000 & 2.000 & 2.000 \\
\hline Teto (R\$) & 0 & 40.000 & 60.000 & 100.000 & 140.000 & 200.000 & 240.000 \\
\hline
\end{tabular}

Onde:

i - quantidade de inconsistências;

g - quantidade de inconsistências graves;

ng - quantidade de inconsistências não graves.

Nesse procedimento, o único aspecto em que resta espaço para relativa subjetividade é a classificação das inconsistências como "graves" ou "não graves". Sobre esse ponto, a Nota Técnica nº 384/2012-SFF/ANEEL explica que

Quanto ao enquadramento da inconsistência como grave, e impossível listar todos os tipos existentes e, mais ainda, a tolerância em que um erro e mais grave ou não em termos absolutos e relativos. Por outro lado, pode-se exemplificar como de dano potencial elevado: (i) aqueles que levem ao calculo equivocado da divida liquida, geração de caixa (receita e despesa do serviço), investimentos, fixação de encargos tarifários e base de remuneração; (ii) a contabilização ausente ou equivocada de ativo e passivo regulatórios, capitalização de despesas da Administração Central (615.04.9), encerramento indevido do exercício e ausência das contas extrapatrimoniais e; (iii) a falta de envio do Balanço Patrimonial, Demonstração de Resultado, Demonstração das Mutações do Patrimônio Liquido e Notas Explicativas societárias e regulatórias no contexto da PAC. Dessa forma, quando da emissão do Auto de Infração, o fiscalizado será cientificado da quantidade de falhas, bem como daquelas classificadas como graves.

Para outro tipo de fiscalização, que se destina a quantificar o Ativo Imobilizado em Serviço - AIS e a Base de Remuneração Regulatória - BRR das empresas de distribuição em seu processo de Revisão Tarifária Periódica - RTE, a SFF aplica metodologia distinta ${ }^{16}$.

\footnotetext{
${ }^{16}$ Reajustes e Revisões são mecanismos pelos quais as tarifas de energia elétrica são alteradas. Estão previstos nos Contratos de Concessão e permitem a manutenção do equilíbrio econômico-financeiro das empresas. A Revisão Tarifária Periódica - RTE ocorre a cada quatro anos, em média, e considera, entre diversos fatores, a Base de Remuneração Regulatória - BRR da empresa. O Ativo Imobilizado em Serviço - AIS é um dos itens que compõem a BRR.
} 
Nesse caso a multa é calculada sobre o repasse tarifário indevido que a empresa receberia durante quatro anos se a infração não fosse identificada pela fiscalização, e não sobre o faturamento anual da empresa autuada.

A Tabela 7.4 resume essa prática da SFF, que permite a imposição de penalidade equivalente a até $40 \%$ do repasse indevido calculado.

Tabela 7.4 - Critério da SFF para irregularidade no AIS e na BRR

Fonte: Elaboração própria

\begin{tabular}{c|c}
\hline Critério & Percentual sobre o repasse indevido em quatro anos \\
\hline Abrangência & Entre 0 e $7,5 \%$ \\
\hline Gravidade & Entre 0 e $7,5 \%$ \\
\hline Danos & Entre 0 e 5\% (à concessão) e entre 0 e 5\% (aos consumidores) \\
\hline Vantagens & Entre 0 e $10 \%$ \\
\hline Sanções irrecorríveis & Entre 0 e $5 \%$ \\
\hline
\end{tabular}

Após a obtenção do percentual (de até $40 \%$ ), a SFF verifica se o valor não excede a proporção de $1 \%$ sobre o faturamento da empresa nos últimos doze meses, pois infrações desse tipo são enquadradas no grupo III descrito na REN nº 63/2004, a que correspondem multas de até $1 \%$ sobre esse montante.

A SFF não definiu de maneira objetiva como são fixados os percentuais entre os limites definidos na Tabela 7.4 para cada critério considerado, de modo que o procedimento depende de avaliação subjetiva da autoridade que lavra o auto de infração. A exceção é o critério "sanções irrecorríveis", que é considerado conforme a Tabela 7.5, a seguir.

Tabela 7.5 - Critério da SFF para sanções irrecorríveis (irregularidade no AIS e na BRR)

Fonte: Elaboração própria

\begin{tabular}{c|c|c|c|c|c}
\hline Número de sanções & $\mathbf{1} \rightarrow \mathbf{3}$ & $\mathbf{4} \rightarrow \mathbf{6}$ & $\mathbf{7} \rightarrow \mathbf{9}$ & $\mathbf{1 0} \rightarrow \mathbf{1 2}$ & $>\mathbf{= 1 3}$ \\
\hline Percentual & $1 \%$ & $2 \%$ & $3 \%$ & $4 \%$ & $5 \%$ \\
\hline
\end{tabular}

A principal diferença dessa metodologia da SFF em relação às demais (utilizadas por SFE, SFG e pela própria SFF) é que a sanção é proporcional à vantagem que seria auferida pela empresa, e não ao seu faturamento.

Essas regras parecem ser aplicadas pela SFF em todos os autos de infração que lavra contra as empresas que cometem infrações em suas atividades no âmbito do acompanhamento 
econômico-financeiro da concessão, porém, como no caso da SFE, não se exclui a possibilidade de existência de outros métodos, não definidos e padronizados, serem utilizados em casos específicos.

\subsection{A prática da Superintendência de Fiscalização dos Serviços de Geração - SFG}

A SFG, por sua vez, não definiu em nota técnica os parâmetros que utiliza para a dosimetria das sanções que aplica. No entanto, os processos administrativos punitivos instaurados pela Superintendência ${ }^{17}$ permitem que se compreenda sua metodologia, ao menos desde meados do ano de 2011. Cada Exposição de Motivos $^{18}$ para auto de infração da SFG descreve os critérios utilizados pela Superintendência de maneira ampla, isto é, não justifica apenas a dosimetria para a multa no caso concreto, mas explicita sua prática nas diversas situações possíveis.

São utilizadas duas fórmulas diferentes, uma para penalidades decorrentes de infrações em empreendimentos em implantação (obras) e outra para as decorrentes de infrações em usinas já em operação.

Para usinas em obras:

$$
M=(0,2 * G+0,5 * D+0,2 * V+0,1 * S) * \text { MaxGrupo } * F_{a t}{ }^{19}
$$

Para usinas em operação:

$$
M=(0,5 * G+0,2 * D+0,2 * V+0,1 * S) * \text { MaxGrupo } * \text { Fat }
$$

\footnotetext{
17 Ver, por exemplo, os processos administrativos 48500.002825/2012-14 (Borborema Energética S.A.), 48500.002945/2012-01 (Maracanaú Geradora de Energia S.A.), 48500.002022/2004-42 (Paracatu Energia S.A.), 48500.005060/2006-18 (Eletrosul Centrais Elétricas S.A.) e 48500.003858/2005-72 (U. S. J. Açúcar e Álcool S.A.). Os anos referenciados nos números desses processos não se referem à lavratura dos autos de infração, mas sim ao início da fiscalização. Todos os autos de infração citados foram lavrados entre 2011 e 2013.

18 "Exposição de Motivos" é o tipo de documento por meio do qual a ANEEL e as Agências Estaduais, em atendimento ao princípio constitucional da motivação dos atos da Administração, explicam as razões que as levaram a lavrar um auto de infração ou a arquivar o termo de notificação, em um determinado processo administrativo punitivo.

${ }^{19}$ Os símbolos nas expressões da SFG representam as mesmas grandezas descritas para a fórmula da SFE.
} 
Nas exposições de motivos para aplicação de penalidades que constam nos processos estudados, a condicionante "abrangência" é tomada pela SFG juntamente com a "gravidade" como uma única variável: “Quanto à abrangência e à gravidade da infração...."

Pode-se compreender a conduta da Superintendência se aceitar-se que quão mais abrangente é uma infração, maior é sua gravidade, de maneira que os critérios podem ser considerados conjuntamente.

Ainda, vê-se nos processos estudados que a SFG utiliza como base para aplicação de multas não o faturamento total da empresa nos doze meses anteriores à aplicação da penalidade, como dispõe a REN n ${ }^{\circ}$ 63/2004, mas sim o faturamento correspondente a sua atividade na usina de geração de energia tida como objeto da ação fiscalizadora. Com essa prática, a SFG considera, já na base de cálculo da multa, a abrangência da infração.

Percebe-se também que a Superintendência não considera o parâmetro "reincidência" em suas fórmulas.

A única diferença de tratamento para as duas situações possíveis de uma usina de geração de energia elétrica diz respeito aos pesos atribuídos aos parâmetros "gravidade" e "danos". A Superintendência parece entender que no caso de uma usina em obras, os danos para o serviço ou para os usuários são potencialmente mais significativos que a gravidade da infração. O contrário se dá para usinas em operação.

A SFG utiliza ainda, considerando fatores como a fonte energética primária da usina, sua relevância para o Sistema Interligado Nacional - SIN, e o ambiente de comercialização de sua energia, valores pré-definidos para as condicionantes "gravidade" e "danos para o serviço e para o usuário"21, como se vê nos quadros que seguem.

Tabela 7.4 - Critério da SFG para gravidade (usinas em obras)

Fonte: Elaboração própria

\begin{tabular}{c|c|c|c}
\hline Fonte primária da usina que ocasionou a infração & Hidrelétrica & Eólica & Térmica ou outras \\
\hline Percentual & $20 \%$ & $10 \%$ & $5 \%$ \\
\hline
\end{tabular}

\footnotetext{
${ }^{20}$ Ver, por exemplo, os processos administrativos punitivos citados na Nota de Rodapé 17.

${ }^{21}$ A SFG utiliza os mesmos percentuais definidos para "ACR" nas Tabelas 7.6 e 7.7 quando a infração é verificada em usina beneficiária de recursos públicos em sua implantação ou operação, como por exemplo, da Conta de Consumo de Combustíveis - CCC ou da Conta de Desenvolvimento Energético - CDE.
} 
Tabela 7.5 - Critério da SFG para gravidade (usinas em operação)

Fonte: Elaboração própria

\begin{tabular}{c|c|c|c}
\hline Modalidade de operação da usina que ocasionou a infração & Tipo I & Tipo II & Tipo III \\
\hline Percentual & $50 \%$ & $30 \%$ & $20 \%$ \\
\hline
\end{tabular}

Tabela 7.6 - Critério da SFG para danos (usinas em obras)

Fonte: Elaboração própria

\begin{tabular}{c|c|c}
\hline Ambiente de comercialização da energia gerada & ACR & ACL \\
\hline Percentual & $50 \%$ & $20 \%$ \\
\hline
\end{tabular}

Tabela 7.7 - Critério da SFG para danos (usinas em operação)

Fonte: Elaboração própria

\begin{tabular}{c|c|c}
\hline Ambiente de comercialização da energia gerada & ACR & ACL \\
\hline Percentual & $20 \%$ & $10 \%$ \\
\hline
\end{tabular}

A condicionante "sanções irrecorríveis nos últimos quatro anos" parece ser utilizada de forma "binária" pela SFG. Caso a empresa autuada apresente sanções irrecorríveis em seu histórico de quatro anos, independentemente do número, é utilizada a condicionante em seu valor máximo permitido pelas fórmulas, que é de $20 \%$, tanto para usinas em obras como para usinas em operação. Caso a empresa não apresente nenhuma sanção irrecorrível em seu histórico de quatro anos, é atribuído o valor "zero" para essa condicionante.

No que tange às "vantagens auferidas" não foi possível identificar a existência de critério objetivo utilizado pela SFG.

Essas regras parecem ser aplicadas pela SFG em todos os autos de infração que lavra contra as empresas que cometem infrações em suas atividades no segmento de geração de

\footnotetext{
${ }^{22}$ O Módulo 26 dos Procedimentos de Rede estabelece os critérios para classificar as usinas segundo sua modalidade de operação, que caracteriza o relacionamento operacional do agente com o ONS e sua relevância para o Sistema Interligado Nacional - SIN. As usinas são classificadas segundo uma das três modalidades a seguir:

Tipo I: usinas conectadas na rede básica - independente da potência líquida injetada no SIN e da natureza da fonte primária; ou usinas cuja operação hidráulica possa afetar a operação de usinas Tipo I já existentes; ou usinas conectadas fora da rede básica cuja máxima potência líquida injetada no SIN contribua para minimizar problemas operativos e proporcionar maior segurança para a rede de operação.

Tipo II: usinas não classificadas como Tipo I, mas que afetam os processos de planejamento, programação da operação, operação em tempo real, normatização, pré-operação e pós-operação.

Tipo III: usinas, individualmente, não classificadas nas modalidades anteriores.

A modalidade de operação da usina é definida a partir da avaliação dos impactos verificados tanto na operação eletroenergética do Sistema Interligado Nacional - SIN, como também na segurança da rede de operação.
} 
energia elétrica, porém, como no caso da SFE e da SFF, não se exclui a possibilidade de outros métodos, não definidos e padronizados, serem utilizados em casos específicos.

\subsection{As Agências Estaduais Conveniadas}

Como regra geral, pode ser dito que as Agências Estaduais utilizam as mesmas regras de dosimetria utilizadas pela Superintendência da ANEEL da qual receberam a delegação para executar a fiscalização e instruir o correspondente processo punitivo.

Isso significa que as Agências que têm contratos com mais de uma Superintendência, como é o caso de muitas, seguem um conjunto de regras diferente conforme o tipo de fiscalização realizada e o ramo da empresa em que a ação se dá. Essa dinâmica exige uma intensa troca de informações entre Superintendências e Agências estaduais e coloca-se como um fator complicador para garantia da isonomia do processo punitivo entre os agentes do setor.

Por outro lado, há que se considerar que as Agências Estaduais, independentemente das metas contratadas com ANEEL, são órgãos independentes e seus funcionários com autoridade para aplicação de sanções podem aplicá-las de forma autônoma, sem necessariamente obedecer a procedimentos internos definidos pelas Superintendências de Fiscalização da ANEEL.

De fato, o equilíbrio entre a isonomia no tratamento às empresas e a independência das Agências na condução de processos punitivos é um aspecto importante da realidade da imposição de sanções no setor elétrico brasileiro.

\subsection{A Diretoria da ANEEL}

Em todos os processos punitivos em que a empresa autuada recorre das decisões proferidas até a última instância administrativa, a discricionariedade específica é também exercida pela Diretoria da ANEEL, no ato em que profere a decisão final para o caso.

A Diretoria não tem um procedimento específico para quantificar as sanções que considera adequadas para as infrações detectadas pelas Superintendências de Fiscalização e pelas Agências Estaduais, tampouco tem uma posição formal definida em favor ou contra as metodologias criadas por essas unidades organizacionais. Aliás, não parece que definições desse tipo sejam parte de sua função: ao colegiado cabe apenas decidir. 
A instância máxima da Agência, por iniciar sua participação no processo punitivo quando os elementos estão todos já presentes (as manifestações da autoridade que impôs a sanção e da empresa autuada), parece preocupar-se fundamentalmente com a adequação da sanção, analisando principalmente as características do caso concreto.

Quanto à isonomia e à segurança jurídica, a principal ferramenta com a qual a Diretoria da ANEEL parece defendê-las em suas decisões é sua própria jurisprudência. Isto é, é comum o embasamento de suas decisões em casos semelhantes julgados anteriormente. No entanto, há que se dizer que não há na ANEEL um dispositivo que sistematize a jurisprudência da Diretoria, de modo que empresas que pretendem conhecê-las devem consultar a integra da divulgação de suas decisões ${ }^{23}$.

Assim, a fase do processo de imposição de sanções em que a decisão final é tomada pela Diretoria da Agência parece ser a que comporta maior subjetividade no exercício da discricionariedade específica.

\footnotetext{
${ }^{23}$ Todos os atos frutos de decisão da diretoria da ANEEL ficam disponíveis no sítio da Agência na internet. Os processos que instruem as decisões também podem ser consultados na íntegra mediante pedido de vistas ou cópia à Agência. Ainda, as reuniões nas quais a diretoria toma suas decisões são públicas e transmitidas ao vivo via internet. Nelas, há a possibilidade de "sustentação oral" de representante da empresa interessada no processo.
} 


\section{O PERFIL DAS SANÇÕES APLICADAS PELA ANEEL}

Desde a criação da ANEEL até o fim mês de novembro de 2013, suas Superintendências de Fiscalização e Agências Estaduais conveniadas instauraram 2.491 processos com sanções retributivas às empresas que atuam no setor elétrico brasileiro na forma de multa ou advertência, cujos valores somados chegam a um montante de mais de dois bilhões e meio de reais $(\mathrm{R} \$ 2.701 .755 .878,71)$. Esses números cresceram enormemente ao longo dos anos. O número de sanções aplicadas em 2012, por exemplo, representa mais de 10 vezes a quantia aplicada em 2002 (372 contra 35 sanções), e o valor total das multas em 2012 é equivalente a aproximadamente 16 vezes o montante de 2002 ( R \$ 692.546.861,95 contra R\$ $42.927 .864,61)^{24}$.

À frente, é fornecida uma visão dos principais parâmetros da atividade sancionadora da Agência, como a quantidade de multas aplicadas, seus valores e sua distribuição ao longo da cadeia de produção e dos tipos de infração, com o objetivo de prover uma percepção quantitativa do processo.

\subsection{Considerações preliminares}

A quase totalidade das sanções aplicadas pela ANEEL se constitui de multas e advertências, impetradas por meio de autos de infração. Ao longo de seus mais de quinze anos de atividade, a Agência emitiu muito poucas sanções retributivas de outros tipos: aproximadamente 120 (cento e vinte) revogações de autorizações (para empreendimentos de geração), perto de uma dezena de intervenções administrativas (em empresas de distribuição) e apenas uma recomendação de caducidade de concessão (também a uma empresa de distribuição). Estas sanções são impetradas por meio de termos de intimação.

Dada a preponderância dos autos de infração, os números apresentados a seguir referem-se somente às multas e advertências impostas pela ANEEL, sendo que as últimas são

\footnotetext{
${ }^{24}$ Esses números se referem ao valor de face dos autos de infração e incluem os autos que ainda não tiveram sua tramitação encerrada na esfera administrativa, ou seja, que ainda não foram julgados pela Diretoria da ANEEL.
} 
tratadas como "multas de valor zero". Essa abordagem permite que se faça avaliações considerando-se apenas dois atributos: "quantidade" e "valor" das sanções aplicadas ${ }^{25}$.

Os dados sobre as multas foram obtidos em dois sistemas computacionais desenvolvidos pela ANEEL: o SIGEFIS - Sistema de Gestão da Fiscalização e o SIGEC Sistema de Gerenciamento de Créditos. O primeiro é utilizado pelas Superintendências de Fiscalização e pelas Agências Estaduais para gerenciamento do fluxo de ações relacionadas às fiscalizações, entre elas a lavratura de autos de infração. O segundo é utilizado pela Superintendência de Administração e Finanças - SAF, para gerenciamento da cobrança das multas.

No cruzamento dos dados dos dois sistemas, foram detectadas algumas inconsistências nos valores das multas, que foram corrigidas uma a uma com base em informações disponíveis no sítio da ANEEL na internet e, em alguns casos, nos próprios processos administrativos punitivos.

As informações aqui apresentadas foram verificadas nos bancos de dados do SIGEFIS e do SIGEC via “consulta SQL” em 28 de novembro de 2013.

\subsection{Os números}

A Figura 8.1 mostra o número de autos de infração lavrados pela ANEEL e por suas Agências Estaduais conveniadas ao longo dos anos. A série azul representa o total de autos lavrados, inclusive os que ainda estão tramitando em fase de recurso. A série vermelha considera apenas os autos com tramitação encerrada na esfera administrativa.

\footnotetext{
${ }^{25}$ Obviamente, o atributo "valor" não pode ser facilmente avaliado em uma intervenção administrativa ou em uma revogação de autorização, por exemplo.
} 


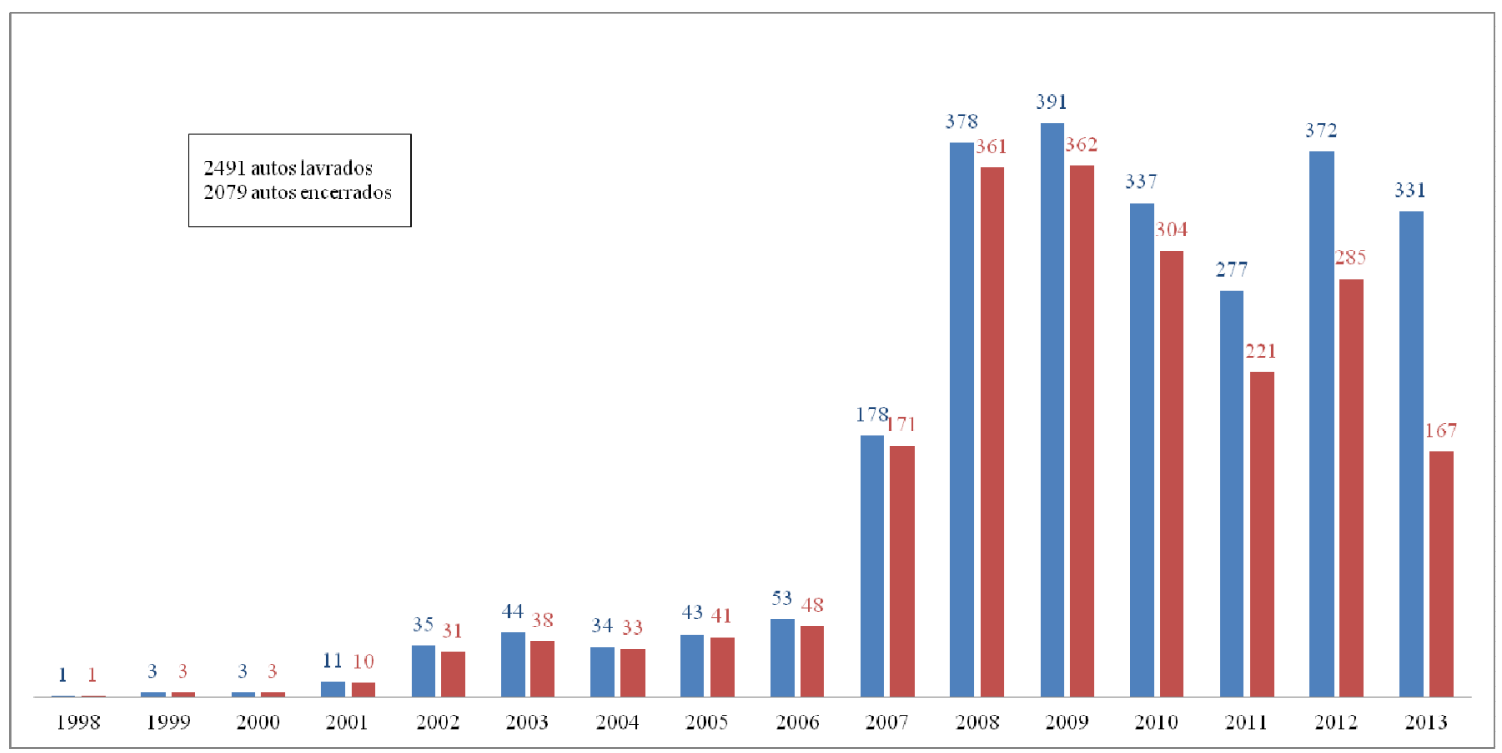

\section{Autos Lavrados autos Encerrados}

Figura 8.1 - Quantidade de autos de infração lavrados por ano

Fonte: Elaboração própria com dados do SIGEFIS e do SIGEC (ANEEL)

Vê-se que a imposição de sanções tornou-se uma atividade corriqueira para a Agência a partir do ano de 2007, e que o número de sanções impostas consolidou-se em um patamar relativamente estável a partir de 2008.

Pode-se cogitar que entre 1998 e 2006 a ANEEL tenha priorizado uma postura orientativa em relação às empresas do setor elétrico, e que, tendo considerado suficientemente grande essa fase, tenha então adotado uma atitude mais firme em termos de imposição de sanções.

Outra hipótese a ser considerada é a de que esse período inicial tenha sido necessário a um desenvolvimento da própria Agência, no que se refere à consolidação de sua estrutura, corpo técnico e métodos de fiscalização.

A Figura 8.2 mostra a relação entre os valores de face (iniciais) dos autos emitidos e seus valores finais na esfera administrativa. O levantamento não considera, obviamente, os autos que ainda estão em fase de recurso, assim como os cancelados. Os valores das colunas representam a soma dos valores dos autos lavrados no ano de referência. As colunas azuis representam os valores de iniciais e as colunas vermelhas os valores finais. A linha verde traça a relação percentual entre os dois montantes. 


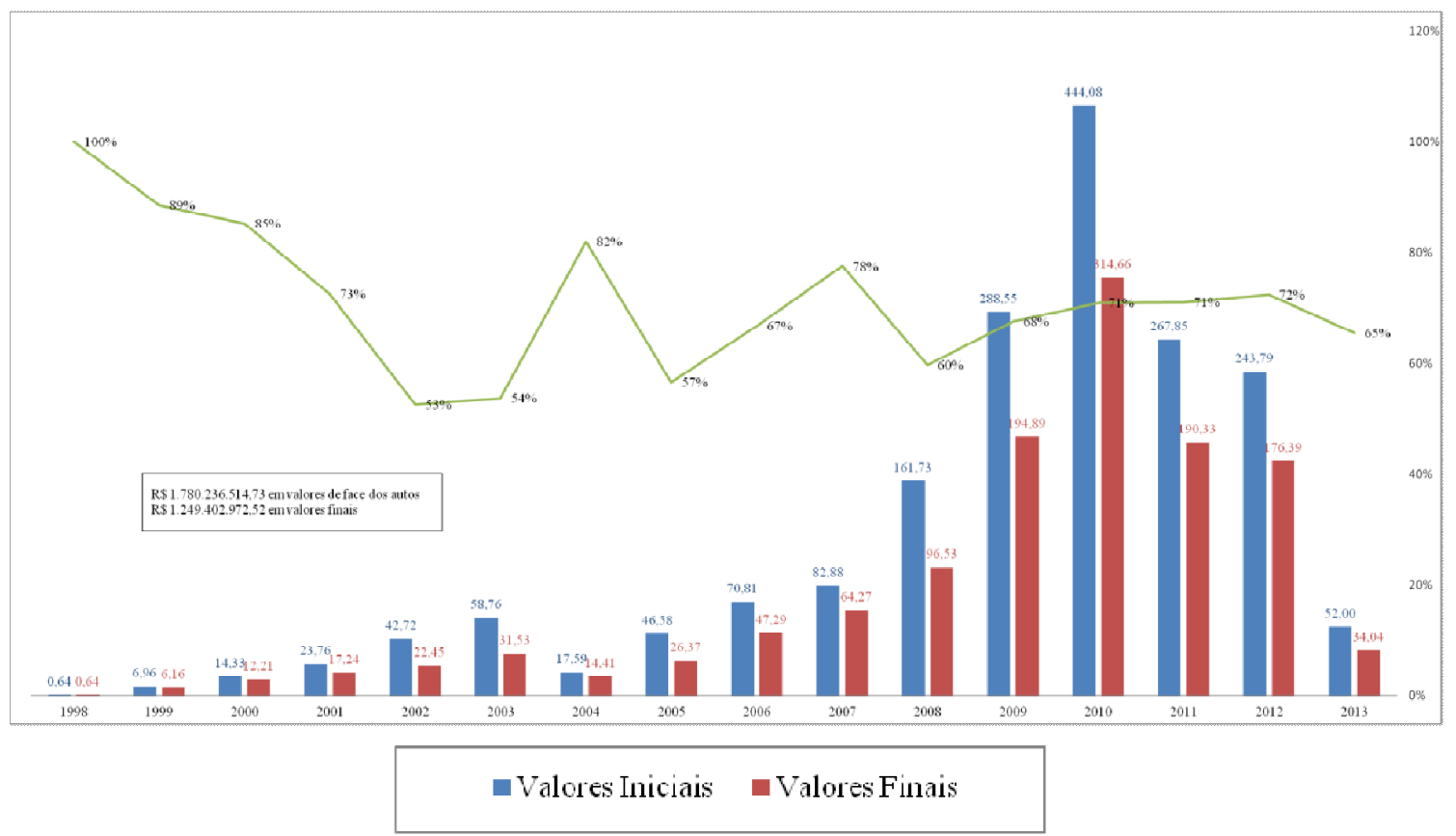

Figura 8.2 - Valores iniciais e finais dos autos de infração lavrados (R \$ milhões)

Fonte: Elaboração própria com dados do SIGEFIS e do SIGEC (ANEEL)

Percebe-se que as empresas têm um relativo sucesso em diminuir, por meio dos recursos impetrados, os valores das multas que lhe são impostas. A relação entre a soma dos valores finais e a dos valores iniciais dos autos têm se mantido relativamente estável em um patamar próximo aos $70 \%$.

Essa informação pode ser compreendida como um indicativo de que a Agência é receptiva às argumentações das empresas, não apresentando, portanto, uma postura excessivamente autoritária nos processos de imposição de penalidades.

O gráfico da Figura 8.3 mostra justamente como os autos de infração são "aceitos" pelas empresas que os recebem. Do total de autos (em quantidade e valores), são destacados o montante em que as empresas entraram com recurso à diretoria da Agência, o montante pago, o montante em que as empresas recorreram ao poder judiciário, e o montante em que a ANEEL e a empresa autuada entraram em acordo, e o auto foi convertido em Termo de Ajuste de Conduta - $\mathrm{TAC}^{26}$. Não foram considerados os autos em fase de recurso e os cancelados.

\footnotetext{
${ }^{26} \mathrm{O}$ TAC é um instrumento alternativo à imposição de penalidade decorrente de um processo de fiscalização instaurado. É uma espécie de acordo em que a empresa se compromete a adequar sua conduta às disposições regulamentares. A celebração de TAC entre a ANEEL e as empresas do setor elétrico é regida pela Resolução Normativa $n^{\circ} 333$, de 7 de outubro de 2008 .
} 


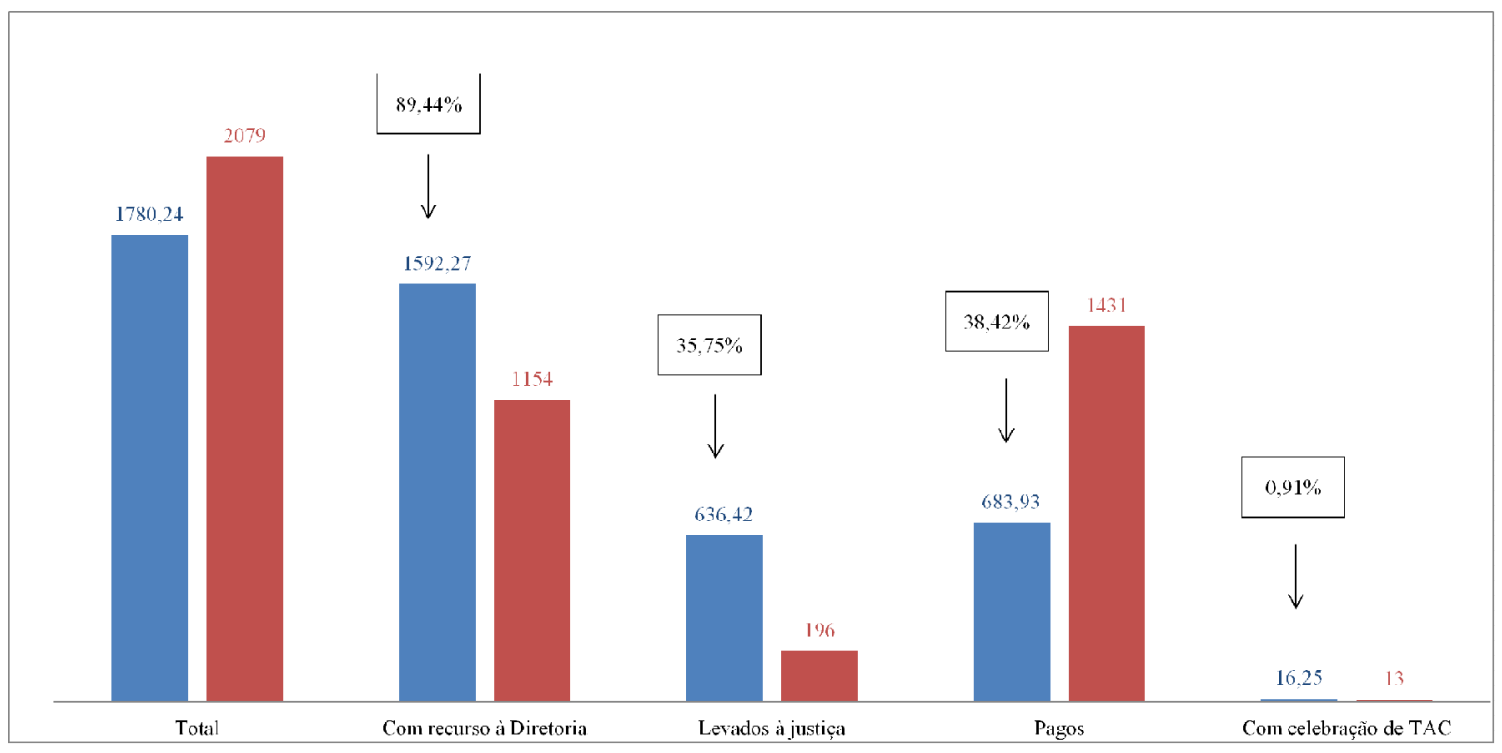

- Valores Quantidades

Figura 8.3 - Recursos administrativos, ações judiciais, autos de infração pagos e celebração de TAC (colunas azuis em R\$ milhões)

Fonte: Elaboração própria com dados do SIGEFIS e do SIGEC (ANEEL)

$\mathrm{Na}$ grande maioria dos processos punitivos $(89,44 \%$, em valores de multa), as empresas do setor elétrico entram com recursos administrativos à Diretoria da ANEEL contra a decisão da Superintendência ou da Agência Estadual que lavrou o auto de infração. Em uma parcela significativa $(35,75 \%)$, a questão é levada ao poder judiciário.

Apenas uma parcela de $38,42 \%$ do valor inicial dos autos emitidos foi efetivamente paga pelas empresas. No restante, os processos estão aguardando decisão judicial ou as empresas estão em situação de inadimplência.

O gráfico mostra também que o TAC foi um instrumento muito pouco utilizado pela ANEEL e suas Agências conveniadas em sua atuação. Não chega a $1 \%(0,91 \%)$ a parcela do valor das multas em que a ANEEL e a empresa apenada firmaram esse tipo de acordo.

A Figura 8.4 detalha o resultado da impetração de recursos administrativos, por parte das empresas à Diretoria da ANEEL, frente às decisões iniciais expressas pelas Superintendências de Fiscalização ou pelas Agências Estaduais. Foram considerados nesse levantamento somente os autos em que a empresa autuada entrou com recurso administrativo, com o objetivo de comparar a decisão da autoridade que imputou a penalidade com a da Diretoria da Agência. Não foram considerados os autos em fase de recurso e os cancelados. 
Os valores das colunas representam a soma dos valores dos autos lavrados no ano de referência. A série azul representa os valores de iniciais e a série vermelha os valores finais. A linha verde traça a relação percentual entre os dois montantes.

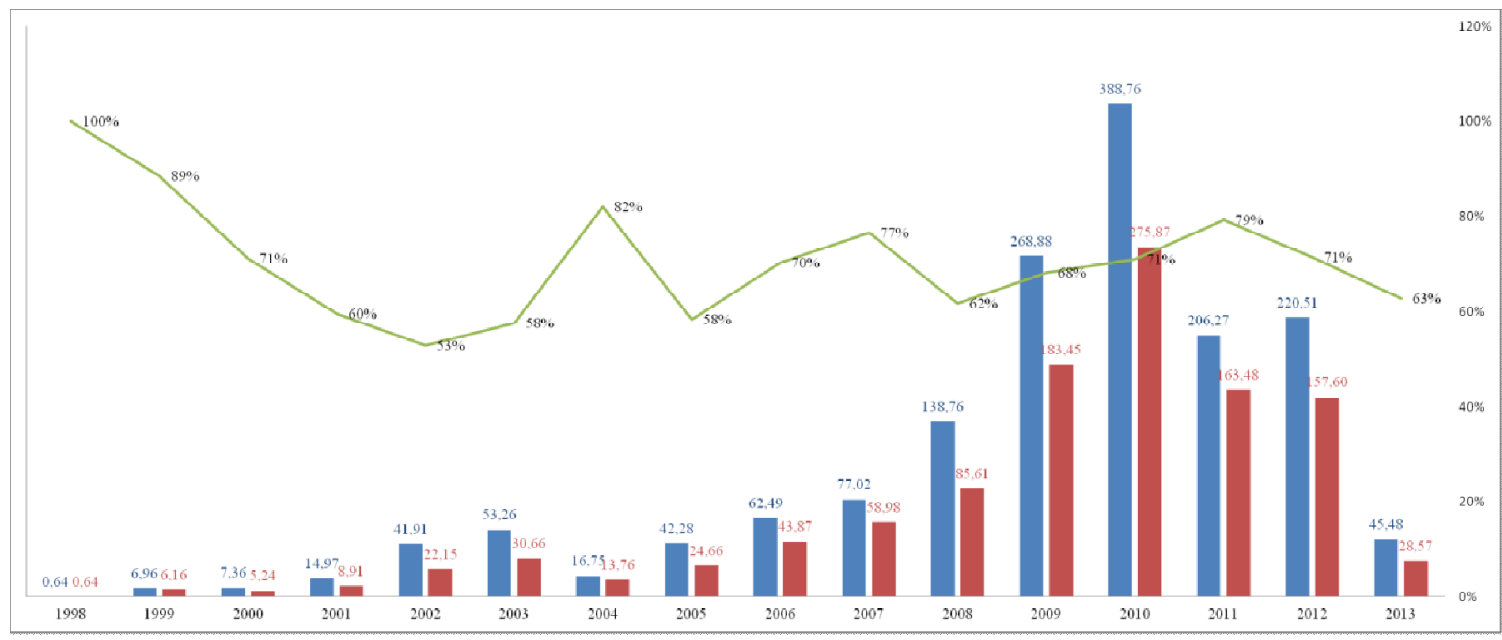

Decisão da Superintendência (ou Agência Lstadual) Decisão da Diretoria da ANLLL

Figura 8.4 - Comparação entre as decisões da Superintendência (ou Agência Estadual) e da Diretoria da ANEEL (R\$ milhões)

Fonte: Elaboração própria com dados do SIGEFIS e do SIGEC (ANEEL)

Nota-se que existe uma considerável diferença entre as decisões das Superintendências ou Agências Estaduais e da Diretoria da ANEEL quanto aos valores das multas aplicadas às empresas. Essa relação tem se mantido praticamente estável em um patamar próximo aos 70\% nos últimos anos.

Essa informação serve como confirmação de que existe independência entre as instâncias decisórias envolvidas nos processos punitivos levados a cabo. Isto é, a Diretoria mostra capacidade de tomar suas decisões sem tornar-se "refém" das exposições técnicas exaradas pelas autoridades que emitiram as multas. Essa independência é atributo essencial de um sistema sancionador que preze pela manutenção da segurança jurídica no mercado regulado.

A seguir, as Figuras 8.5 e 8.6 detalham a quantidade e os valores das multas que foram efetivamente pagas pelas empresas, em relação às decisões finais da ANEEL.

As colunas azuis representam as decisões finais da ANEEL, e as colunas vermelha as multas pagas pelas empresas. Na Figura 8.6, a linha verde mostra a relação percentual entre os 
montantes monetários. Em ambos os gráficos, não foram considerados os autos em fase de recurso e os cancelados.

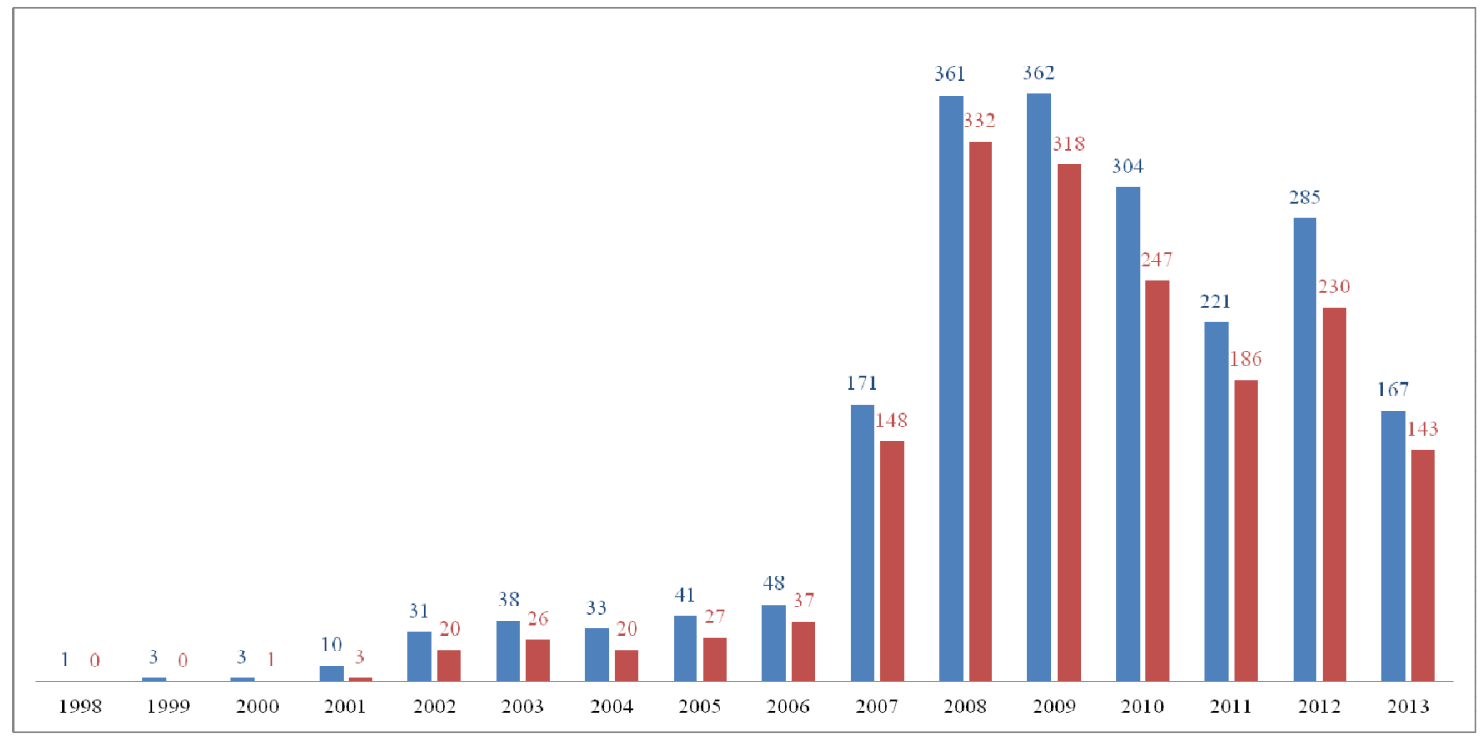

- Autos Emitidos $\quad$ AutosPagos

Figura 8.5 - Quantidade de autos emitidos (conforme última decisão administrativa) e de autos pagos Fonte: Elaboração própria com dados do SIGEFIS e do SIGEC (ANEEL)

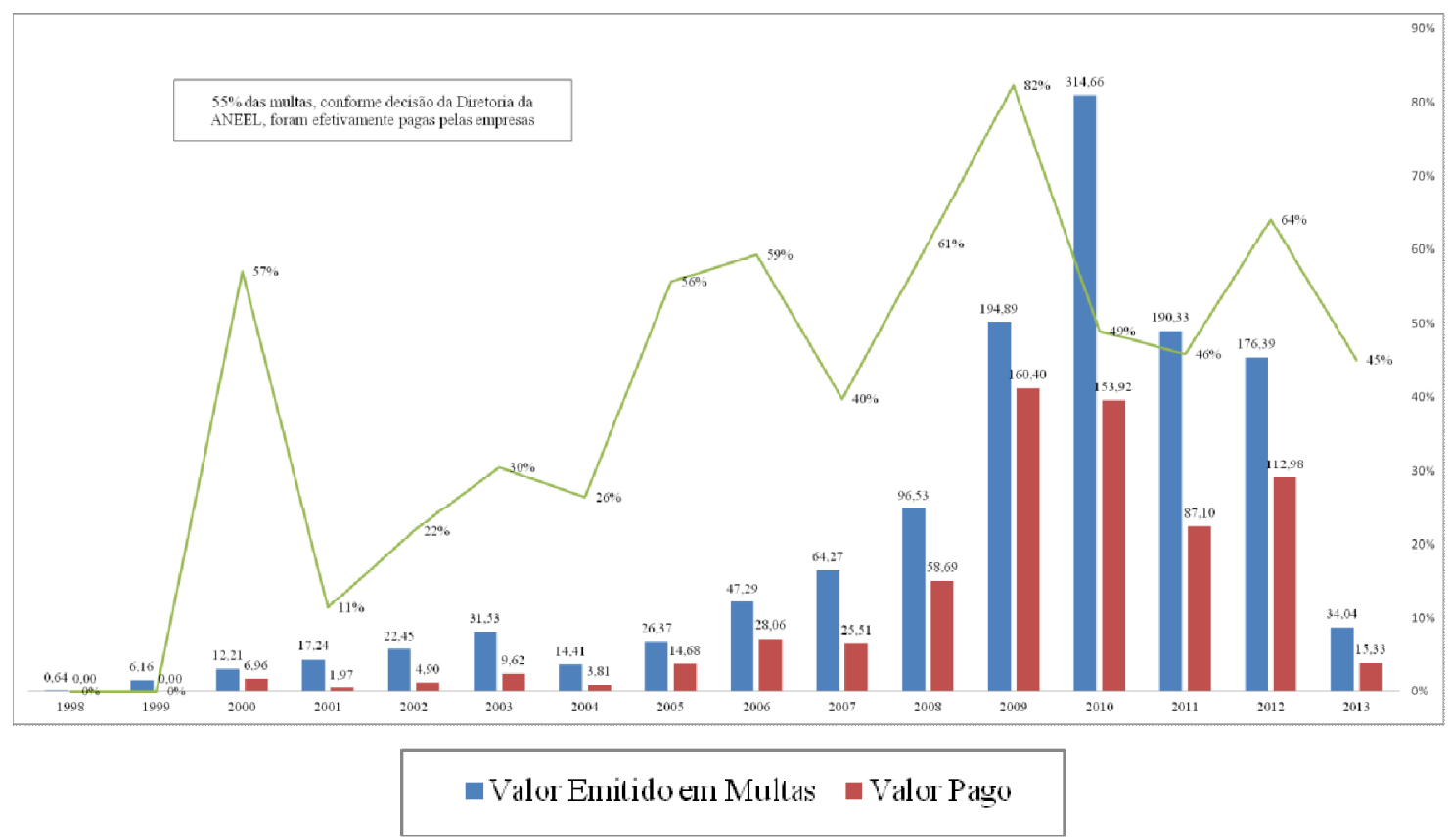

Figura 8.6 - Valores das multas emitidas (conforme última decisão administrativa) e montantes pagos (R\$ milhões)

Fonte: Elaboração própria com dados do SIGEFIS e do SIGEC (ANEEL) 
Percebe-se que a proporção de multas efetivamente pagas vem aumentando com o passar dos anos, mesmo que de forma pouco constante. Pode-se cogitar que essa constatação denote uma crescente credibilidade das decisões da ANEEL, do ponto de vista das empresas. Esse crescimento pode ser visto mais facilmente em termos de quantidade (Figura 8.5), do que em termos de valores (Figura 8.6), o que evidencia que as multas de valores mais baixos são mais facilmente pagas, enquanto as de valores mais expressivos são mais frequentemente objeto de disputas judiciais, ou mesmo razão para que as empresas incorram em inadimplência perante a União.

A Figura 8.7 mostra distribuição das multas aplicadas pela ANEEL e por suas Agências Estaduais conveniadas entre os ramos de atividade das empresas reguladas: geração, transmissão e distribuição de energia elétrica. As colunas azuis representam a soma dos valores das multas em cada ramo de atividade. Os valores expostos são os finais na esfera administrativa. As colunas vermelhas representam a quantidade de autos lavrados. Aqui também não foram considerados os autos em fase de recurso e os cancelados.

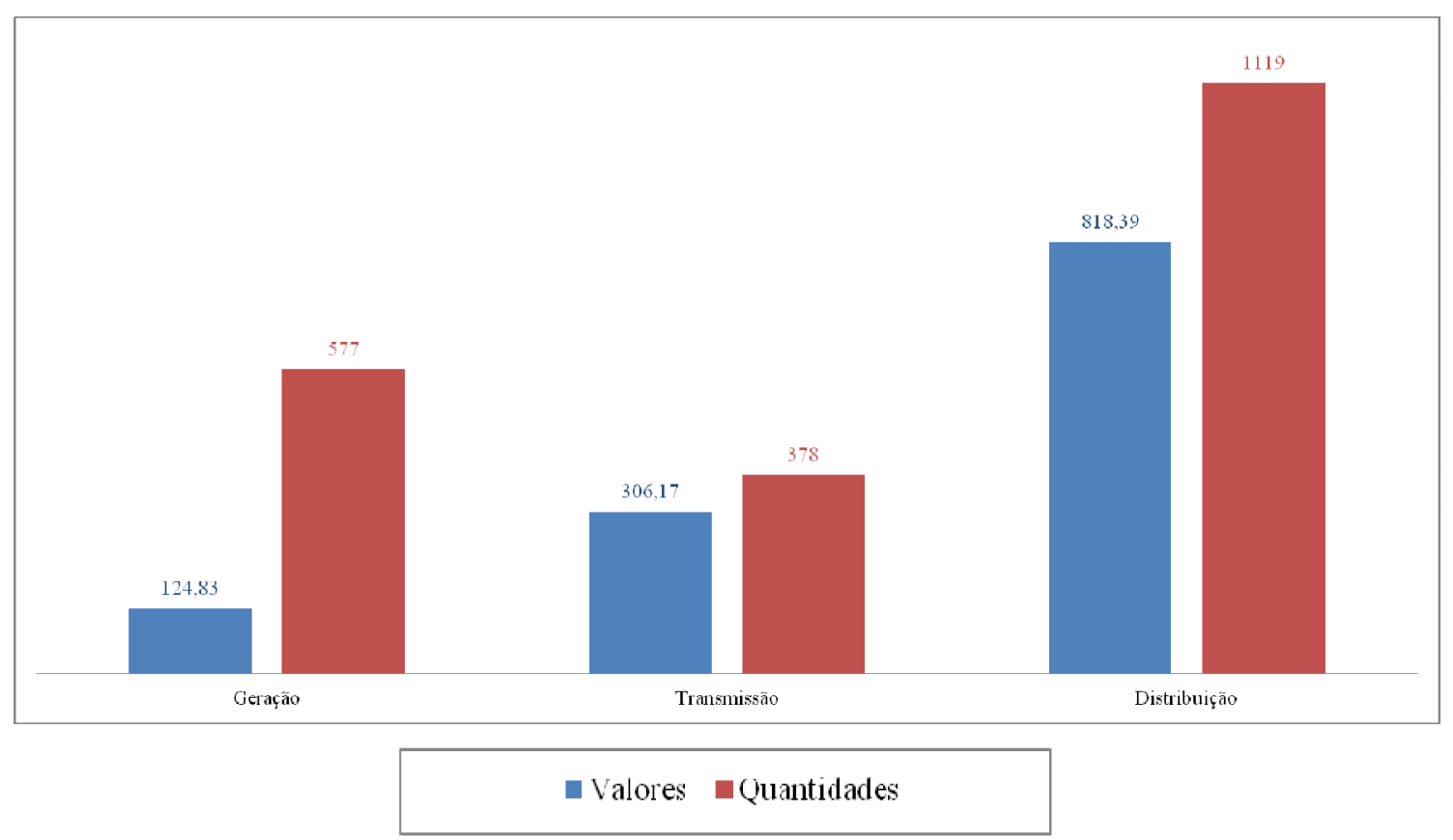

Figura 8.7 - Valores e quantidades de multas por ramo de atividade, conforme última decisão administrativa (colunas azuis em $\mathbf{R} \$$ milhões)

Fonte: Elaboração própria com dados do SIGEFIS e do SIGEC (ANEEL) 
O ramo de atividade que mais sofre imposição de penalidades é o de distribuição, e o que menos sofre é o de geração de energia elétrica. O ramo de transmissão situa-se em posição intermediária.

As multas impostas às empresas de geração são as que possuem menor valor médio, o que decorre diretamente do fato de que essas empresas costuma ter um faturamento anual (que é a base para a aplicação de penalidades) menor do que as empresas dos outros ramos.

Por outro lado, as multas impostas às empresas de distribuição não são as que possuem maior valor médio, e sim aquelas impostas às empresas de transmissão. Apesar das distribuidoras serem as empresas que normalmente possuem um faturamento anual maior, as infrações por elas cometidas dificilmente abrangem a totalidade, ou mesmo uma grande parcela de sua área de concessão, aspecto que acaba por reduzir os valores das multas aplicadas, conforme critérios de dosimetria apresentados no Capítulo 7.

Ainda, as diferenças de quantidade e valores das multas entre cada ramo se justificam pelas diferentes características de cada uma das atividades. É razoável conceber que as empresas de distribuição, por administrarem uma atividade configurada como monopólio natural, e por liderem diretamente com a população (os consumidores), sejam um alvo mais habitual das ações de fiscalização da ANEEL do que as empresas de geração, que atuam em um ambiente competitivo e em que as infrações cometidas poucas vezes têm impacto direto no consumidor de energia elétrica.

A Figura 8.8 mostra, em quantidade e em valores finais das multas, a distribuição dos autos de infração lavrados por cada Superintendência de Fiscalização ou Agência Estadual.

As barras azuis mostram os valores e as vermelhas as quantidades. Novamente, não foram considerados os autos em fase de recurso e os cancelados. 


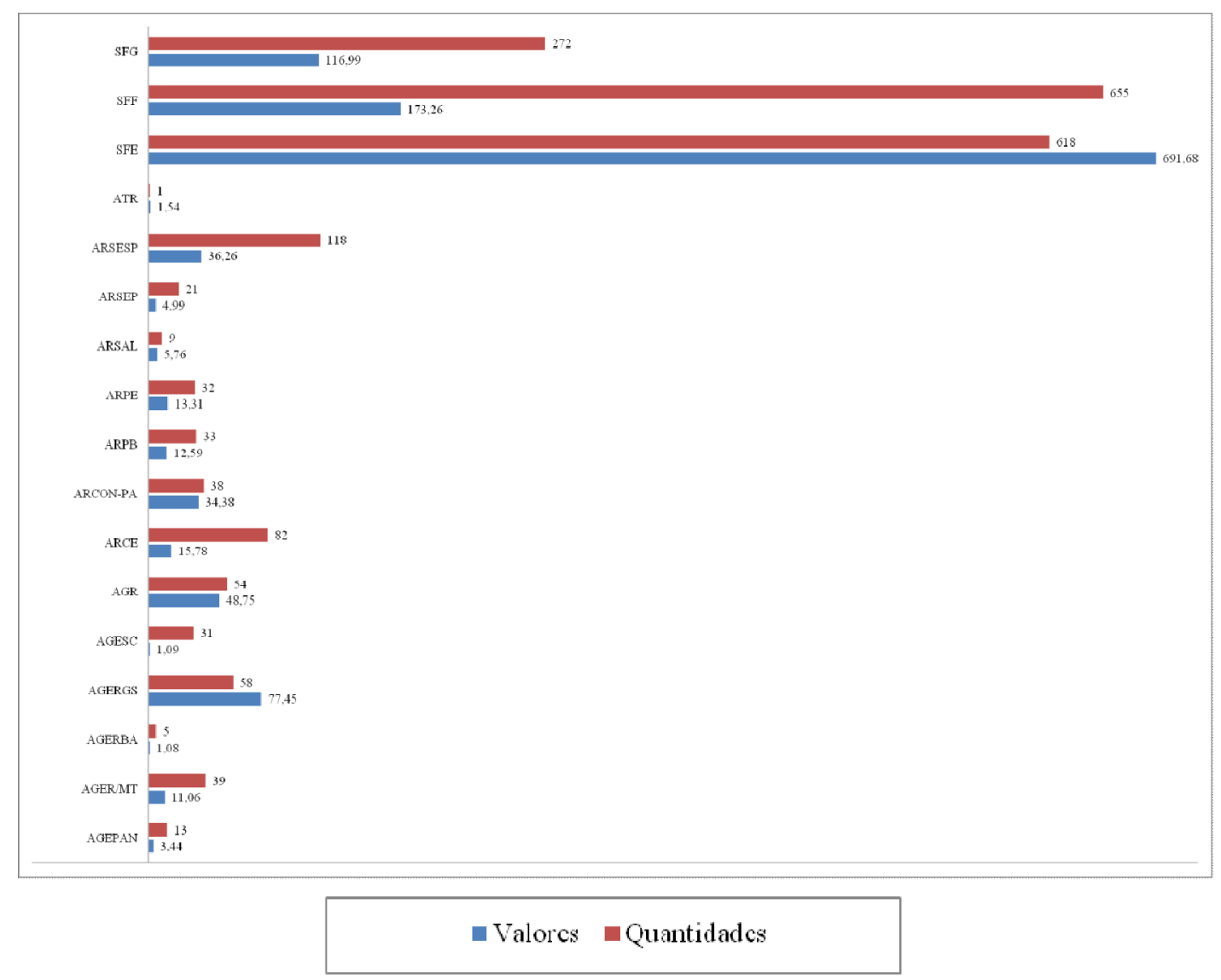

Figura 8.8 - Valores e quantidades de multas por Superintendência ou Agência Estadual, conforme última decisão administrativa (barras azuis em $\mathbf{R} \$$ milhões)

Fonte: Elaboração própria com dados do SIGEFIS e do SIGEC (ANEEL)

Vê-se que a atividade sancionadora realizada centralizadamente é mais significativa que a realizada de forma descentralizada, tanto em termos de quantidade quanto de valores das multas em decisão final.

Os autos emitidos pelas Agências Estaduais representam aproximadamente 25\% do total em quantidade, e aproximadamente $20 \%$ em valor das multas impostas. Entre as Superintendências de Fiscalização da ANEEL, a SFF é a que emitiu a maior quantidade de autos de infração, e a SFE é a que impôs o maior valor em multas às empresas. A SFG possui os menores números nos dois atributos.

O gráfico da Figura 8.9 mostra, em quantidade e em valores finais das multas, a distribuição dos autos de infração lavrados contra as empresas reguladas pela ANEEL. São apresentadas as 40 empresas mais multadas, em valor.

As barras azuis mostram os valores e as vermelhas as quantidades. Não foram considerados os autos em fase de recurso e os cancelados. 


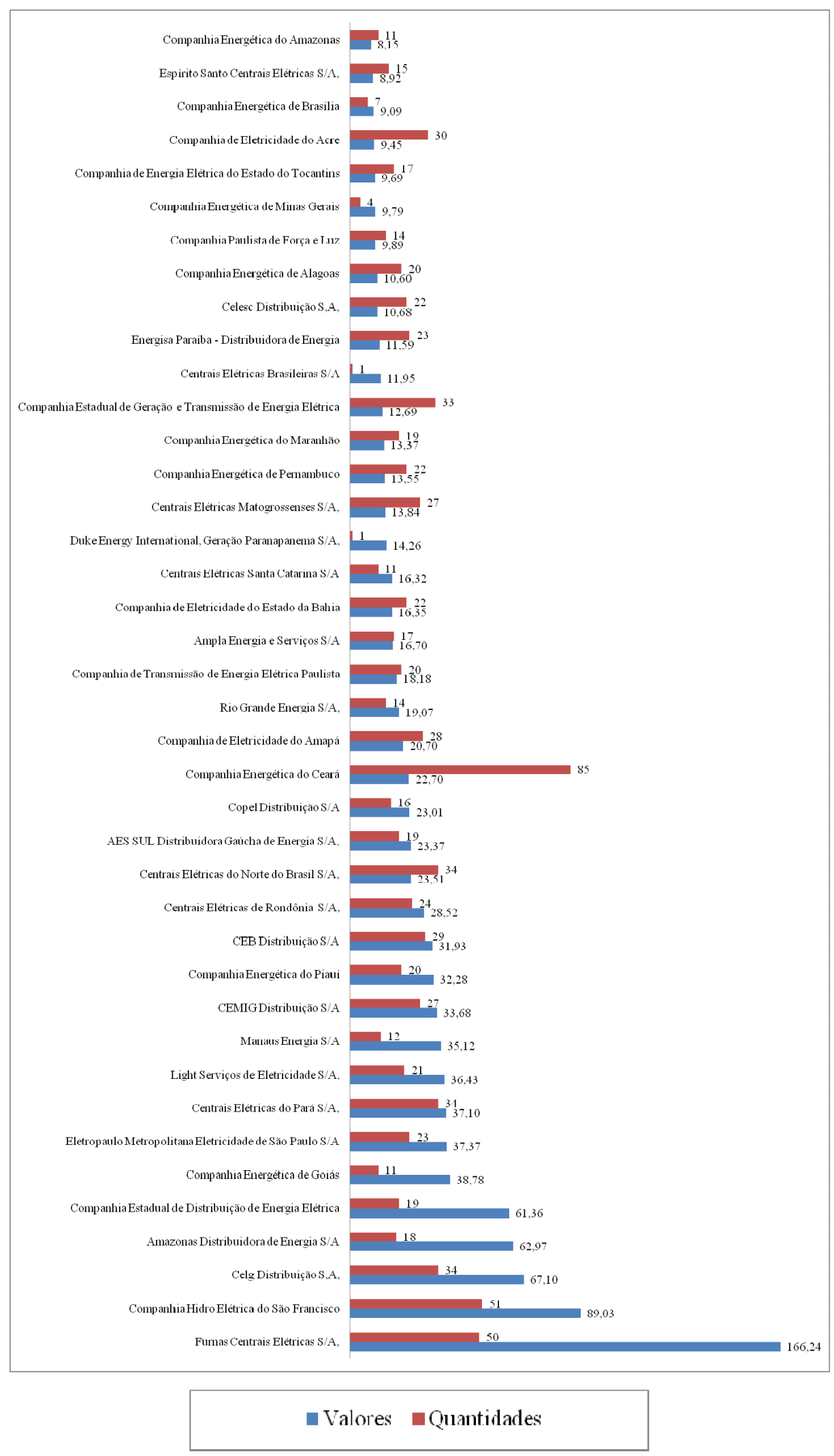

Figura 8.9 - Valores e quantidades de multas para as 40 empresas mais multadas (barras azuis em R\$ milhões)

Fonte: Elaboração própria com dados do SIGEFIS e do SIGEC (ANEEL) 
A Empresa mais multada, em termos de valor final das multas, é Furnas Centrais Elétricas S.A. - FURNAS, que acumulou mais de 166 milhões de reais em penalidades, em 50 diferentes autos de infração, decorrentes de sua atividade nos ramo de geração e transmissão. A empresa mais multada, em quantidade, é a Companhia Energética do Ceará - COELCE, com 85 autos recebidos por infrações cometidas em sua atividade de distribuição, que perfazem um total de aproximadamente 22 milhões de reais.

Juntas, essas 40 empresas receberam aproximadamente $91 \%$ do valor total aplicado em multas pela ANEEL e suas Agências Estaduais conveniadas. O valor das multas impostas às 10 empresas mais multadas representa aproximadamente $51 \%$ do total.

Das 40 empresas listadas, 34 atuam na distribuição de energia elétrica, dado que corrobora a tese de que os esforços de fiscalização da ANEEL são mais são mais focados nesse ramo de atividade.

A Figura 8.10 apresenta a relação das 40 empresas mais multadas em termos de porcentagem sobre seu faturamento anual.

É importante ressaltar que o faturamento das empresas varia conforme o período considerado, bem como que há variações significativas no período considerado, que é de mais de 15 anos. Os valores foram obtidos somando-se a porcentagem que o valor de cada penalidade representa sobre o faturamento do período que foi considerado para sua lavratura.

Para esse levantamento, só foram considerados os autos de infração para os quais o faturamento de referência estava disponível nos sistemas computacionais da ANEEL (SIGEC ou SIGEFIS). Esses são 1.392 dos 2.079 autos lavrados, cuja tramitação já foi encerrada na esfera administrativa. 


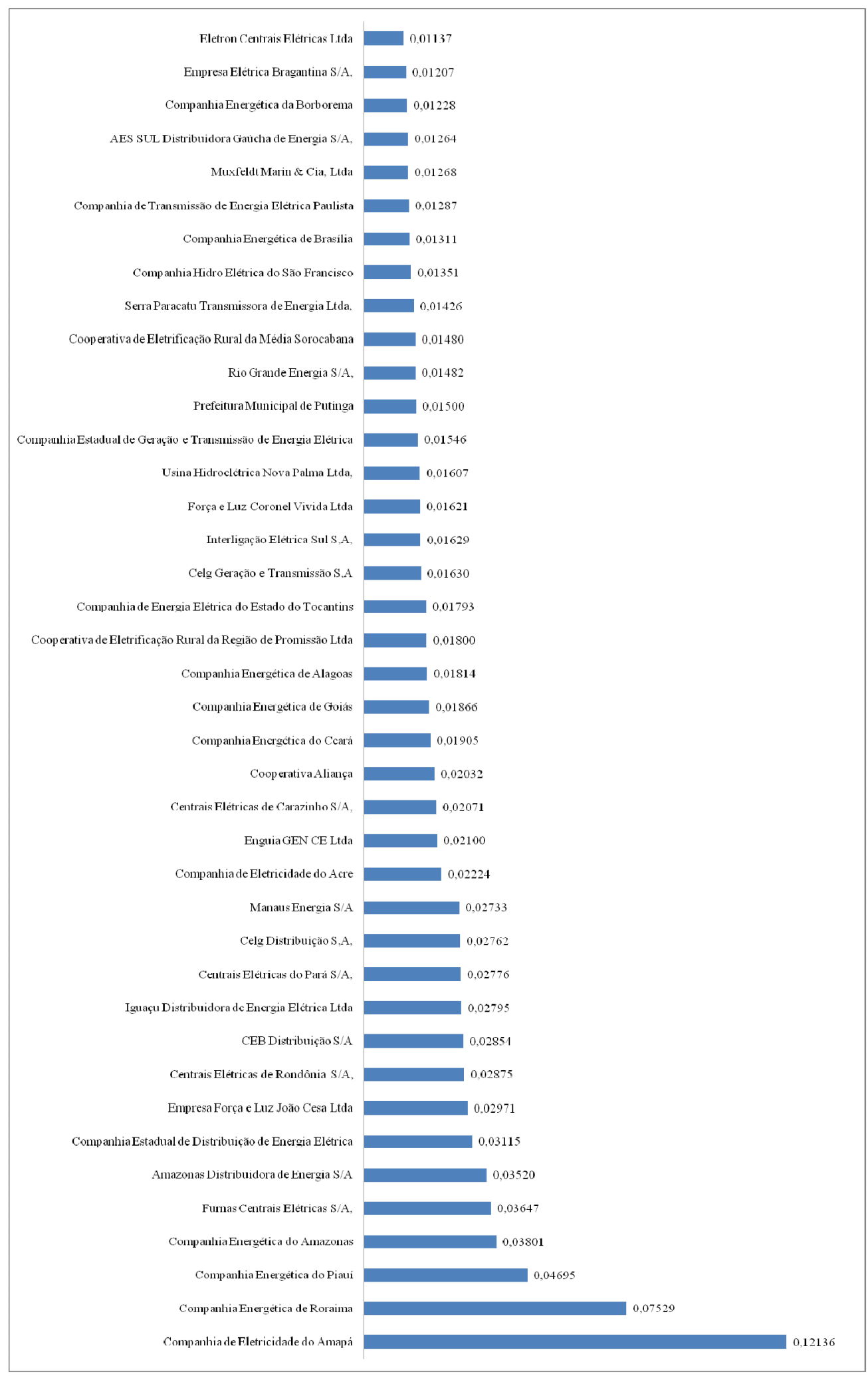

Figura 8.10 - As 40 empresas mais multadas, em termos da relação do valor das multas sobre seu faturamento em 12 meses (\%)

Fonte: Elaboração própria com dados do SIGEFIS e do SIGEC (ANEEL) 
A empresa mais multada é, de longe, a Companhia de Eletricidade do Amapá - CEA, que já recebeu o equivalente a 12,136\% de seu faturamento em 12 meses em multas da ANEEL. Essa empresa atua no ramo de distribuição e, em 2007 a ANEEL recomendou ao MME a declaração de caducidade de sua concessão, sanção que até o momento não foi executada.

Das 40 empresas listadas, 31 são distribuidoras de energia elétrica.

Por fim, a Figura 8.11 traça o perfil da aplicação de multas da ANEEL ao longo dos anos, em termos de porcentagem do valor total das multas aplicadas sobre o faturamento total das empresas multadas.

Nesse levantamento, também só foram considerados os 1.392 autos de infração lavrados e encerrados na esfera administrativa para os quais a informação sobre o faturamento da empresa está disponível.

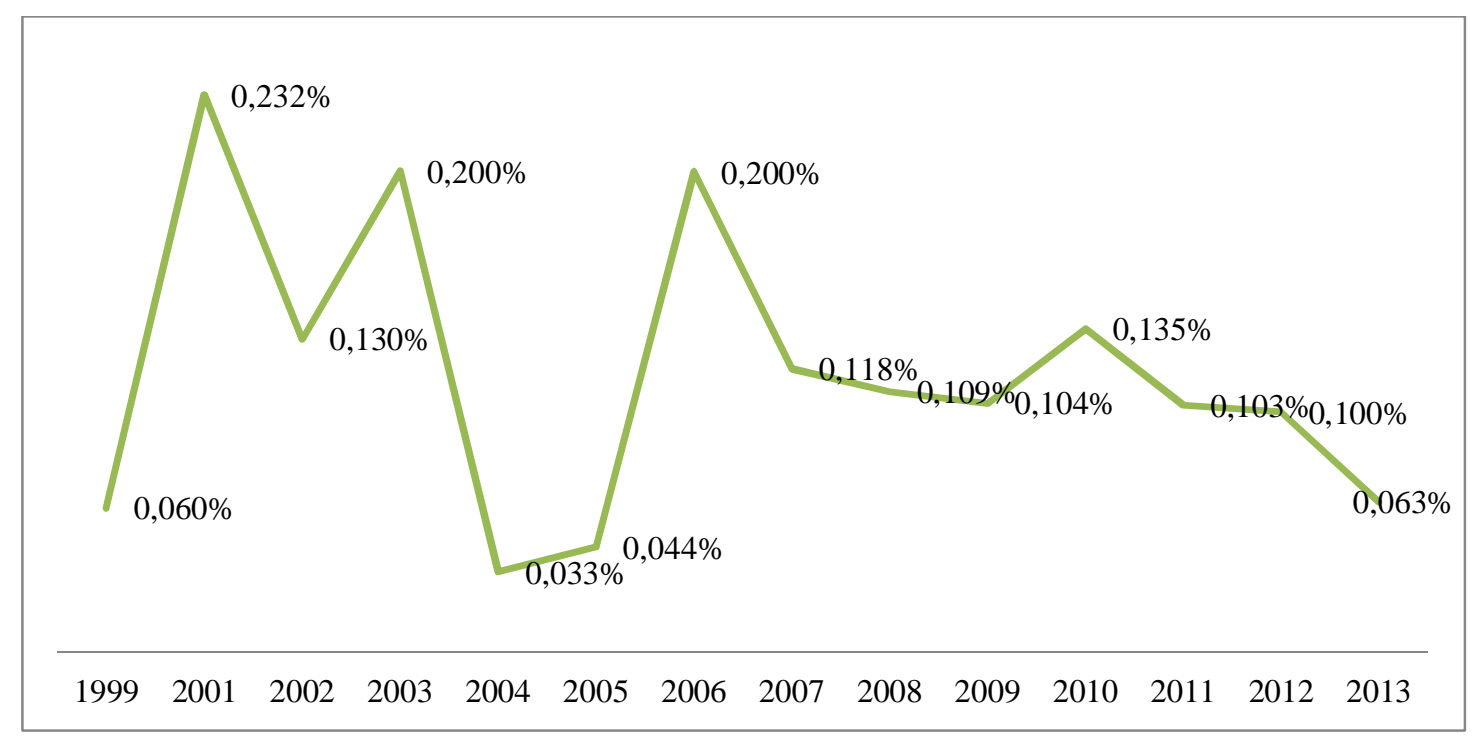

Figura 8.11 - Relação entre o valor das multas e o faturamento das empresas, por ano Fonte: Elaboração própria com dados do SIGEFIS e do SIGEC (ANEEL)

Vê-se que, desde 2008, o valor das multas emitidas pela ANEEL ou por suas Agências Estaduais conveniadas situa-se em torno de $0,1 \%$ do faturamento anual das empresas autuadas. Esse valor pode ser entendido como a "dosimetria média" das multas aplicadas. 


\section{CONSIDERAÇÕES SOBRE A REN No 63/2004 E SOBRE SUA APLICAÇÃO}

Este Capítulo apresenta considerações sobre a regulamentação da ANEEL a respeito da imposição de sanções às empresas por ela reguladas.

São avaliados a tipificação das infrações; os grupos de infrações e seus respectivos valores máximos permitidos para multas; os critérios dispostos para definição do valor das penalidades e sua forma de consideração; e o procedimento estabelecido para sua imposição às empresas.

Por fim, é avaliada a compreensão das unidades organizacionais (Superintendências, Agências Estaduais e Diretoria) sobre as disposições da REN nº 63/2004, bem como sobre sua forma de aplicação.

As considerações se apoiam no direito administrativo sancionador e na regulação econômica, e buscam avaliar o "resultado regulatório" da regulamentação e de sua aplicação, isto é, a sua efetividade como incentivo ao cumprimento da regulamentação e ao bom funcionamento do mercado de energia elétrica.

\subsection{Sobre a tipificação das infrações}

Tipificação é o nome que se dá ao ato de classificar algo em tipos. E tipo é a ordenação dos dados concretos existentes na realidade segundo critérios de semelhança.

No direito penal, tipos são padrões de conduta por meio do qual o Estado descreve ações que pretende impedir, ou exigir que sejam levadas a efeito pelos cidadãos.

Segundo Martins (2008),

O tipo é predominantemente descritivo, porque os elementos descritivos são os mais importantes para individualizar uma conduta e, dentre eles, o verbo tem especial significação, pois é precisamente a palavra que gramaticalmente serve para conotar uma ação.

$[\ldots]$

Não se deve confundir o tipo com a tipicidade. O tipo é a fórmula que pertence à lei, enquanto a tipicidade pertence à conduta.

A extensa lista de infrações disposta na REN nº 63/2004 demonstra um esforço do regulador em descrever detalhadamente as condutas que entende como infratoras em tipos, 
para que assim as sanções que impõe atendam ao princípio da tipicidade. A questão que se coloca é se esse nível de detalhamento é necessário e realmente benéfico aos agentes envolvidos no processo, isto é, as empresas do setor e a própria ANEEL.

Desde sua publicação, a Resolução já foi alterada diversas vezes ${ }^{27}$, e a maioria das alterações foi no sentido de incluir ou excluir tipos de infração, ou ainda mudar sua correspondência com as diferentes penalidades possíveis.

Essas alterações parecem ter decorrido da válida percepção do regulador da necessidade de tipificar infrações que antes não estavam previstas. Porém, acabaram por deixar os tipos sem uniformidade quanto ao nível de especificidade, sem relação clara de hierarquia e com sobreposições quanto às condutas infratoras que abrangem.

Para ilustrar a falta de uniformidade entre os níveis de especificidade, podem ser elencados, por exemplo, os tipos infracionais descritos no artigo $4^{\circ}$, incisos XVI, XVII e XVIII da REN no 63/2004:

Art. $4^{\circ}$ Constitui infração, sujeita à imposição da penalidade de multa do Grupo I:

$[\ldots]$

XVI - deixar de remeter à ANEEL, nos prazos estabelecidos, as informações e os documentos solicitados para a solução de divergências entre agentes ou entre estes e seus consumidores;

XVII - deixar de encaminhar à ANEEL, nos prazos e condições estabelecidos, as informações referentes aos contratos de compra e venda de energia elétrica negociados;

XVIII - deixar de prestar informações solicitadas pela ANEEL no prazo estabelecido;

Enquanto os incisos XVI e XVII apresentam infrações bem específicas quanto à não disponibilização de informações à ANEEL, o inciso XVIII expõe esse mesmo tipo de infração de forma mais genérica, sem especificar exatamente o tipo de informação não disponibilizada. Esses dispositivos ilustram também uma situação em que os tipos apresentam sobreposição de condutas descritas como infratoras.

A existência desses três tipos parece desnecessária, sobretudo se considerarmos o fato de que a todos eles correspondem penalidades idênticas: multa do grupo I.

Outro exemplo de diferentes níveis de especificidade pode ser percebido na comparação entre os tipos descritos no artigo $5^{\circ}$, incisos XVIII e XII da REN no 63/2004:

Art. $5^{\circ}$ Constitui infração, sujeita à imposição da penalidade de multa do Grupo II:

$[\ldots]$

VIII - descumprir as regras e procedimentos estabelecidos para a implantação ou operação das instalações de geração, transmissão e distribuição de energia elétrica;

$[\ldots]$

\footnotetext{
${ }^{27}$ Ver Nota de Rodapé 12.
} 
XII - operar centrais geradoras ou instalações da rede básica sem a instalação de medidores de energia elétrica e demais equipamentos de medição exigidos;

Enquanto um inciso descreve de maneira genérica o descumprimento de regras na implantação e na operação de instalações, o outro descreve especificamente o descumprimento de uma dessas regras: operar as instalações sem medidores. Esses tipos também apresentam sobreposição quanto às condutas que abrangem, e a sua existência concomitante parece ainda mais desnecessária se notarmos que a eles correspondem penalidades idênticas: multa do grupo II.

Quanto à sobreposição de condutas infratoras pelos tipos, os exemplos citados se referem a tipos alocados em um mesmo grupo, mas esse problema ocorre também entre tipos alocados em grupos diferentes. Nesse caso, as consequências da sobreposição são maiores, pois, dependendo da tipificação considerada, o impacto financeiro da sanção pode ser maior ou menor, em uma larga escala de variação.

Um exemplo dessa situação pode ser verificado na sanção aplicada pela ARSESP à Companhia Leste Paulista de Energia - CPFL Leste ${ }^{28}$, em razão de não conformidades constatadas em seu processo de ressarcimento de danos elétricos a consumidores.

A opção da Agência Estadual foi utilizar o tipo infracional descrito no artigo $4^{\circ}$, inciso IV da REN no 63/2004:

Art. $4^{\circ}$ Constitui infração, sujeita à imposição da penalidade de multa do Grupo I:

$[\ldots]$

IV - deixar de atender pedido de serviços nos prazos e condições estabelecidos na legislação e/ou no contrato;

A empresa, no entanto, requereu em seu recurso ao auto de infração a tipificação da falta no artigo $3^{\circ}$, inciso III da resolução:

Art. $3^{\circ}$ Constitui infração, sujeita à imposição da penalidade de advertência:

$[\ldots]$

III - deixar de prestar informações aos consumidores, quando solicitado ou conforme determinado pela legislação e regulamentos ou pelo contrato de concessão;

Já a SFE, quando consultada sobre o assunto, opinou pela utilização do tipo descrito no artigo $6^{\circ}$, inciso I da norma:

Art. $6^{\circ}$ Constitui infração, sujeita à imposição da penalidade de multa do Grupo III:

$[\ldots]$

\footnotetext{
${ }^{28}$ Processo administrativo $\mathrm{n}^{\mathrm{o}}$ 48500.000181/2013-92. A constatação da equipe de fiscalização referia-se ao fato de a Distribuidora não ter investigado a existência de nexo de causalidade entre ocorrências em sua rede de operação e os danos elétricos causados aos consumidores, e mesmo assim, ter considerado seus pedidos de ressarcimento de danos improcedentes.
} 
I - descumprir as disposições legais, regulamentares e contratuais relativas aos níveis de qualidade dos serviços e do fornecimento de energia elétrica;

Na prática, enquanto o pleito da empresa geraria uma sanção de advertência, as opções da ARSESP e da SFE acarretariam, para a mesma infração, penalidades de R \$ 1.118,24 e R\$ $111.824,26$, respectivamente.

Em sua decisão final, a Diretoria da ANEEL acompanhou o voto do diretor relator, que enunciou:

A meu ver, a proposta da CPFL realmente não se enquadra na infração cometida e a proposta pela SFE não é mais específica do que o enquadramento utilizado pela ARSESP, mas, na prática, o enquadramento efetuado pela ARSESP me pareceu o mais adequado, pois é mais próximo do que aconteceu. Por isso, havendo duas possibilidades, parece-me prudente escolher aquele que resultou na multa original.

Um exemplo de falta de clareza na hierarquia entre as condutas descritas como infrações na REN no 63/2004 pode ser constatado pela comparação entre os tipos infracionais descritos no artigo $4^{\circ}$, inciso XV e no artigo $5^{\circ}$, inciso II da norma:

Art. $4^{\circ}$ Constitui infração, sujeita à imposição da penalidade de multa do Grupo I:

$[\ldots]$

XV - deixar de utilizar equipamentos, instalações e métodos operativos que garantam a prestação de serviço adequado;

$[\ldots]$

Art. $5^{\circ}$ Constitui infração, sujeita à imposição da penalidade de multa do Grupo II:

$[\ldots]$

II - descumprir obrigações regulamentares ou contratuais de manter registro atualizado das reclamações e solicitações dos consumidores, com anotação da data e do motivo, bem como de informar ao interessado, no prazo estabelecido, as providências adotadas;

Enquanto a conduta de não garantir a prestação do serviço adequado é correspondente à penalidade do grupo I, a prática de não manter atualizado o registro de reclamações dos consumidores (possivelmente sobre a inadequação do serviço) é correspondente à penalidade do grupo II, que é potencialmente dez vezes maior.

Conclui-se que esses problemas, que se apresentam como potencial fonte de insegurança jurídica, são inerentes à tentativa de tipificar detalhadamente as infrações possíveis em um ambiente complexo e dinâmico como o setor elétrico brasileiro. 


\subsection{Sobre os grupos de infrações e os valores máximos das multas}

Sendo o limite máximo de $2 \%$ em relação ao faturamento anual da empresa autuada a única restrição imposta legalmente (art. $3^{\circ}, X$ da Lei $n^{\circ}$ 9.427/1996) quanto ao estabelecimento de valores das multas aplicadas pela ANEEL, vê-se que, dentro desse limite a Agência tem ampla margem de discricionariedade para regulamentar sua ação.

A prática atual, conforme definida na REN nº 63/2004, consiste em regulamentar valores máximos por grupo de infrações tipificadas e, dentro desses grupos, deixar às Superintendências de Fiscalização e Agências Estaduais a tarefa de definir, caso a caso, mas segundo critérios também pré-determinados pela Norma, a dosimetria exata de cada multa.

Nessa dinâmica, entende-se inicialmente que o primeiro grupo definido pela Norma (grupo I) tem seu limite máximo de multa $(0,01 \%$ do faturamento da empresa nos últimos doze meses) "muito pequeno", de modo que uma multa enquadrada em tipos desse grupo parece ter um efeito sobre a empresa muito próximo do que teria uma sanção de advertência.

A título de exemplo, a distribuidora Eletropaulo Metropolitana Eletricidade de São Paulo S.A., que foi a empresa regulada com o maior faturamento no período de janeiro a dezembro de 2012, da ordem de $\mathrm{R} \$ 10$ bilhões, poderia ser alvo de uma multa desse grupo com valor máximo da ordem de R 1 milhão ${ }^{29}$.

Castro, Brandão e Ozório (2011) apontam que um grupo de seis distribuidoras, entre elas a Eletropaulo, obteve no ano de 2009 uma receita líquida de $\mathrm{R}$ \$ 35,21 bilhões e um lucro líquido de R \$ 4,09 bilhões. Já a ABRADEE (2013) mostra que da composição da tarifa média nacional no ano de 2012, $18 \%$ do valor foram destinados à atividade de distribuição, dentre os quais $4 \%$ formaram a remuneração das empresas do segmento. Por esses dois estudos, podese considerar que o lucro líquido das distribuidoras de energia elétrica nos anos recentes situou-se entre $11,6 \%(4,09 / 35,21)$ e $22,2 \%(4 / 18)$.

Desse modo, o recebimento de uma multa do grupo I (com dosimetria máxima permitida) poderia representar, para essas empresas uma frustração financeira situada entre 1/2222 e 1/1160 sobre seu lucro líquido anual.

Uma vez compreendido como "muito pequeno" o "degrau" entre advertência e multa de $0,01 \%$ do faturamento anual de uma empresa, há que se reconhecer como "muito grandes" os "degraus" entre os valores máximos estabelecidos para multas dos grupos I e II (a última

${ }^{29}$ O valor exato do faturamento da empresa no ano de 2012, conforme dados da ANEEL, foi de R\$ 10.233.481.598,10, de modo que o valor exato da multa hipotética citada como exemplo, se aplicada sobre essa base, seria de R\$1.023.348,16. 
com valor máximo de 0,1\%), e para as multas dos grupos II e III (a última com valor máximo de 1\%). Em ambos os casos, a diferença é de dez vezes, ou seja, os valores crescem exponencialmente entre esses grupos. A variação total entre os valores máximos previstos para as multas aplicáveis pela ANEEL (grupos I e IV) é de em duzentas vezes.

Parece ser desnecessário ao pleno exercício da discricionariedade garantido à autoridade que define a dosimetria das multas um intervalo de tamanha magnitude. Ainda, esse intervalo não parece ser necessário para descrever a hierarquia entre as infrações possíveis no setor elétrico.

\subsection{Sobre os critérios}

O Decreto $\mathrm{n}^{\mathrm{o}} 2.335 / 1997$ foi a primeira norma a definir critérios para o estabelecimento do valor das multas aplicadas pela ANEEL: natureza, gravidade e reincidência ( $\operatorname{art.} 17, \S 4^{\circ}$ ). A REN n ${ }^{\circ}$ 63/2004 fala em abrangência, gravidade, danos (para o serviço ou para os usuários), vantagens (para a empresa), existência de sanções nos últimos quatro anos e reincidência.

O aumento no número de critérios levado a cabo pela regulamentação da ANEEL pode ser entendido como um esforço da Agência em traduzir os critérios descritos no Decreto em aspectos verificáveis na ocasião da constatação de uma infração. Assim, os critérios "abrangência", "gravidade", "danos" e "vantagens" descritos na Resolução podem ser vistos como desdobramentos do termo "gravidade" do Decreto. Do mesmo modo, a "existência de sanções" e a "reincidência" descritas na Resolução podem ser vistas como desdobramentos da "reincidência" citada no Decreto, o primeiro critério tratando de uma espécie de "reincidência geral", isto é, considerando quaisquer tipos de infrações cometidas, e o segundo tratando de "reincidência específica", ou seja, considerando infrações idênticas à que está sendo objeto de sanção.

Por essa linha de raciocínio pode-se perguntar sobre como traduziu a ANEEL, em sua

regulamentação, o critério "natureza" constante no Decreto no 2.335/1997. Entende-se que a natureza da infração é definida na REN n 63/2004 por seu tipo, que, uma vez estando associado a grupos de valores máximos da penalidade possível, permite que o critério "natureza" seja considerado no estabelecimento do valor das sanções, como manda o Decreto. 
A Figura 9.1 a seguir demonstra a relação entre os critérios listados no Decreto $\mathrm{n}^{\circ}$ 2.335/1997 e na REN nº 63/2004.
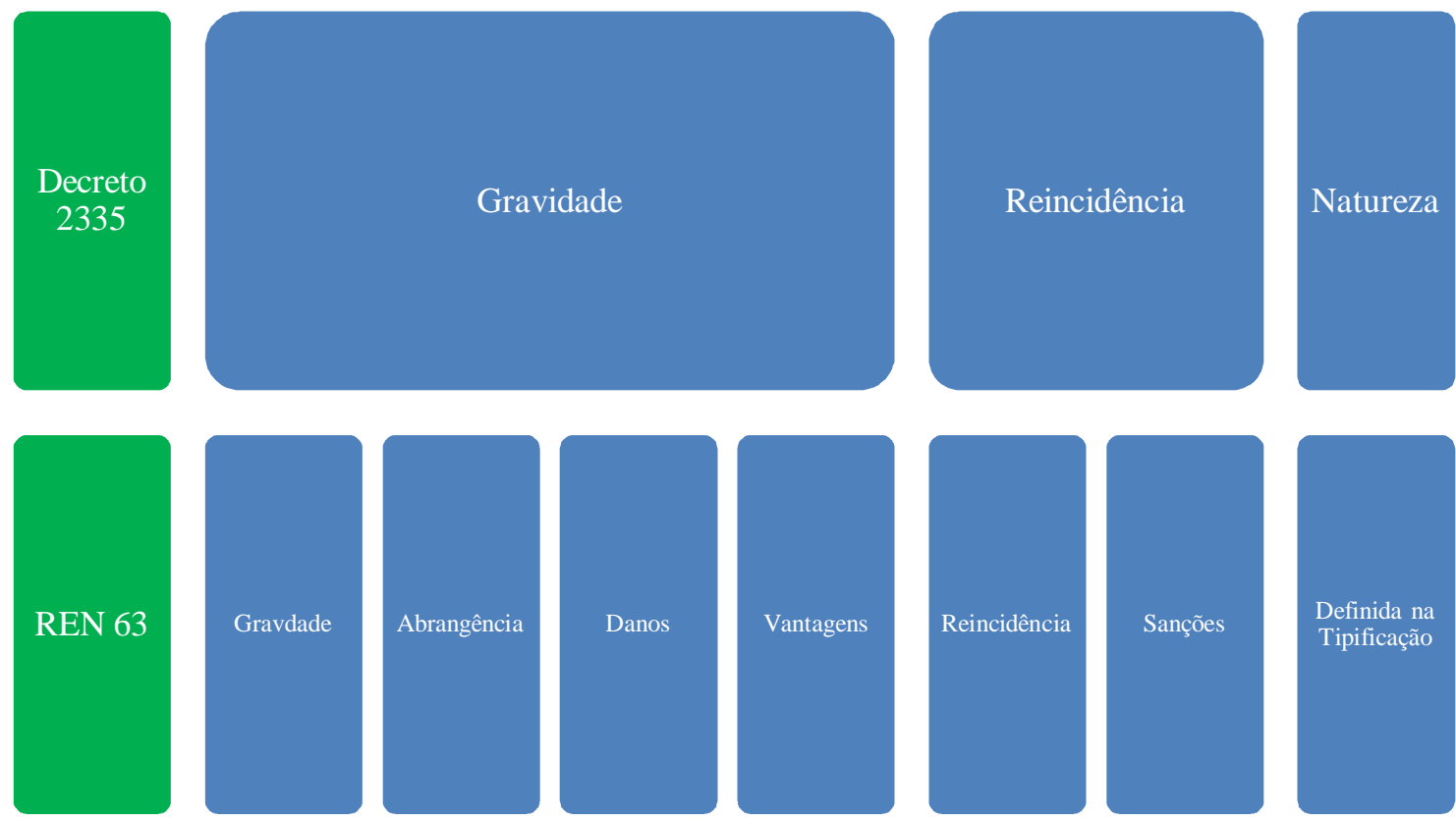

Figura 9.1 - Relação entre critérios para definição de valores de multas (Decreto no $2.335 / 1996$ e REN no 63/2004)

Fonte: Elaboração própria

Essa expansão do número de critérios realizada pela regulamentação da Agência constitui-se, no entanto, como potencial fonte de incertezas sobre o processo de estabelecimento do valor de sanções, uma vez que aumenta a quantidade de dimensões em que pode ser exercida a discricionariedade específica.

Ainda, da mesma forma que se compreende a utilização do critério "natureza" exigido pelo Decreto $\mathrm{n}^{\mathrm{o}} 2.335 / 1996$ na medida em que se enquadra a infração em um dos tipos previstos, pode-se considerar que o critério "gravidade" também é levado em conta quando se aloca o tipo escolhido em um dos grupos de valores máximos de sanção. Por essa compreensão, infrações mais graves seriam descritas por tipos alocados no grupo IV (multa máxima de 2\%), e infrações menos graves, por tipos alocados no grupo I (multa máxima de $0,01 \%$ ).

Desse modo, percebe-se que a REN no 63/2004, permite que o critério "gravidade" seja considerado duas vezes no processo de estabelecimento do valor das multas, 
primeiramente pela própria norma, e posteriormente pela autoridade que instrui o processo punitivo.

Entende-se que essa dupla consideração da "gravidade" não traz vantagens ao processo, mas constitui-se como desnecessário fator complicador à aplicação e ao entendimento da atividade sancionadora da ANEEL.

\subsection{Sobre os procedimentos de fiscalização e de aplicação de penalidades}

Conforme descrito no fluxograma da Figura 6.2, considera-se bastante claro o procedimento de arguição entre a empresa autuada e a ANEEL, isto é, a troca de informações entre as partes envolvidas após a apresentação à empresa do Termo de Notificação, documento que descreve a fiscalização realizada, contendo constatações e, eventualmente, não conformidades, determinações e recomendações. Essa parte do processo compreende a manifestação da empresa frente ao termo de notificação, sua análise, a possibilidade de recurso e seu julgamento pela instância superior, a Diretoria da ANEEL.

Observa-se, no entanto, que a Agência não regulamentou o processo de fiscalização (os procedimentos que devem ser seguidos) em sua fase anterior à emissão do termo de notificação. Não há norma que defina os princípios gerais de atuação da fiscalização, nem a troca de informações com a sociedade sobre as prioridades no planejamento de suas ações. E não há norma que defina os procedimentos e meios de fiscalização, ou que ao menos exija das Superintendências essa definição.

Ainda, não há regulamentação que exija das Superintendências de Fiscalização uma apresentação geral dos resultados obtidos em seus trabalhos, que não os próprios termos de notificação e autos de infração lavrados. A inexistência desse tipo de apresentação, em formato de relatório periódico, mostra que a ANEEL subutiliza o efeito preventivo das sanções que aplica, pois não as leva eficientemente ao conhecimento do mercado regulado e da sociedade.

Mas é sobre os procedimentos de aplicação de penalidades que reside a indefinição mais importante: a regulamentação existente não define a forma como são considerados os critérios que devem ser utilizados para definição das sanções, limitando-se a descrevê-los. Essa indefinição é extremamente significativa, pois faz com que a dosimetria das sanções propriamente dita (os procedimentos de cálculo) fiquem plenamente sujeitos à discricionariedade específica. E na prática isso significa que as Superintendências de 
Fiscalização e Agências Estaduais conveniadas podem calcular as multas praticamente como bem entenderem.

Ainda, a REN no 63/2004 não traz, para as Superintendências de Fiscalização, a exigência de publicidade desses procedimentos de cálculo, nem de que haja uniformidade entre suas práticas.

Essas lacunas na regulamentação colocam-se como empecilhos à percepção de segurança jurídica para as empresas reguladas perante a ação fiscalizadora da Agência. Para a sociedade de maneira geral, colocam-se como obstáculo à plena compreensão sobre o trabalho de fiscalização realizado.

\subsection{Sobre a aplicação da REN n 63/2004}

A definição da metodologia de construção de valores das multas em documentos como notas técnicas, ou mesmo no caso da SFG, no qual essa definição é feita na exposição de motivos dos autos de infração, demonstra o esforço das Superintendências em sistematizar o exercício da discricionariedade específica, a elas autorizado pela regulamentação, conferindo maior grau de isonomia e estabilidade ao processo. Dessa forma, elas acrescentam à discricionariedade específica uma roupagem de discricionariedade geral, mas com a importante diferença de que essas regras não são feitas por meio de atos normativos, portanto não são objeto de audiência pública ou análise de impacto regulatório e, mais importante, não tem poder de autovinculação das decisões dessas Superintendências.

Sem uma sistematização mínima, certamente infrações idênticas seriam punidas com sanções distintas, principalmente se considerarmos a realidade da regulação do setor elétrico brasileiro, em que centenas de servidores públicos trabalham em processos punitivos na ANEEL e nas Agências Estaduais com ela conveniadas. Seria praticamente impossível garantir a isonomia no tratamento dado às empresas.

Por outro lado, é importante que as autoridades que impõem sanções não fiquem "engessadas" por procedimentos rígidos, o que resultaria em um cerceamento de sua "discricionariedade específica".

É essencial também que, mesmo sem alterar a metodologia por elas definida, reste a essas autoridades a possibilidade de alterar a dosimetria em casos específicos, sempre que as circunstâncias assim exigirem e sempre de forma justificada. 
Há que se compreender também a impossibilidade de definição de procedimentos para aplicação de penalidades decorrentes de infrações sui generis. O mesmo se pode dizer sobre infrações cometidas por agentes sui generis, como o ONS e a CCEE. Nesses casos cabe ao regulador calcar-se no princípio da razoabilidade.

Quanto às diferenças entre os procedimentos adotados pelas Superintendências, é razoável compreender pelo menos parte delas como necessárias, uma vez que as realidades das atividades que fiscalizam são diferentes entre si. De fato, os parâmetros para definição de sanções utilizados no caso de uma empresa podem ser reproduzidos no caso de outras, dentro de um mesmo ramo (geração, transmissão ou distribuição), mas essa afirmação pode não ser verdadeira quando se avalia processos punitivos impostos a empresas que atuam em ramos diferentes.

Quanto à descentralização da instauração de processos punitivos às Agências Estaduais, a despeito de suas vantagens, essa sistemática constitui-se como um complicador no que tange à isonomia dos procedimentos, uma vez que a discricionariedade proporcionada pela regulamentação é exercida por várias diferentes autoridades, conforme a Unidade Federativa em que atua a empresa fiscalizada.

No entanto, a prática adotada por essas Agências, que consiste em agir conforme as regras adotadas pela Superintendência que a delega cada atividade específica, é bastante razoável, pois, desse modo, resta mantida a isonomia de tratamento em cada um dos ramos de atuação da fiscalização descentralizada: geração, distribuição e econômico-financeira ${ }^{30}$, independentemente da localização geográfica da empresa autuada.

Assim, a manutenção da segurança jurídica presume que as empresas tenham condições de compreender as diferentes regras de imposição de sanções em cada um dos ramos de atuação da fiscalização. É razoável supor que esse cenário é mais favorável a essa compreensão do que um alternativo em que cada Agência Estadual agisse uniformemente em todos os processos de sanção que instrui, e, portanto, as diferenças estariam entre a atuação de Superintendências e Agências, dentro de um mesmo ramo.

Quanto à Diretoria da ANEEL, parece razoável que não defina procedimentos específicos, mas trabalhe adequando, quando necessário, as sanções impostas pelas Superintendências e Agências Estaduais.

Feitas essas considerações, há que se reconhecer que o cenário enfrentado pelas empresas que atuam no setor é bastante complexo se levarmos em conta as diferentes regras

\footnotetext{
${ }^{30}$ A Lei $n^{\circ}$ 9.427/1996 não permite a possibilidade de descentralização da fiscalização dos serviços e das instalações de transmissão (art. 20, II).
} 
de dosimetria (ou, principalmente, a ausência delas) nos procedimentos das três Superintendências de Fiscalização e das Agências Estaduais.

Ainda, conforme mostrado no Capítulo 7, existe nesses procedimentos significativo uso de avaliações subjetivas. De acordo com os critérios deixados à discricionariedade específica pela REN n 63/2004, o quadro a seguir compara a ação das autoridades envolvidas nos processos punitivos no setor elétrico em termos de objetividade ou subjetividade na forma de estabelecer as sanções impostas.

Tabela 9.1 - Subjetividade no exercício da discricionariedade específica

Fonte: Elaboração própria

\begin{tabular}{|c|c|c|c|c|c|}
\hline & SFE & SFF & SFG & Agências Estaduais & Diretoria da ANEEL \\
\hline Abrangência & $\mathrm{o}$ & não utilizado & $\mathrm{o}$ & \multirow{5}{*}{$\begin{array}{l}\text { Atuam de acordo com a } \\
\text { Superintendência para a } \\
\text { qual executam a atividade } \\
\text { de imposição de sanção }\end{array}$} & \multirow{5}{*}{$\mathrm{s}$} \\
\hline Gravidade & s & $\mathrm{o}$ & $\mathrm{o}$ & & \\
\hline Danos & $\mathrm{s}$ & não utilizado & o & & \\
\hline Vantagens & $\mathrm{s}$ & não utilizado & $\mathrm{s}$ & & \\
\hline Sanções & o & não utilizado & o & & \\
\hline
\end{tabular}

Onde:

o - uso de critérios objetivos;

s - uso de critérios subjetivos;

Vê-se que o enorme espaço deixado pela REN no 63/2004 ao exercício da discricionariedade específica, associado à complexidade inerente a um sistema sancionador que cuida de atividades distintas e que são executadas em ambientes regulatórios também complexos e distintos, acabou por possibilitar que as Superintendências de Fiscalização construíssem, cada uma a seu modo, metodologias distintas para cálculo da dosimetria das sanções impostas às empresas reguladas, utilizando para isso, por vezes, avaliações subjetivas.

Isso resulta, para as empresas reguladas, em um cenário complexo, em que é difícil prever as regras de dosimetria com que serão punidas pelas infrações que eventualmente venham a cometer.

Esse cenário é agravado se considerarmos a grande quantidade de atores envolvidos no processo de aplicação de penalidades - três Superintendências, Diretoria e doze Agências Estaduais, bem como a autonomia decisória legalmente conferida a essas últimas. 


\subsection{Considerações gerais}

A simplicidade e, portanto, a possibilidade de sua plena compreensão por parte das empresas reguladas, parece ser atributo essencial de um sistema sancionador adequado a um ambiente ao qual é cara a manutenção da segurança jurídica.

Os principais empecilhos para a garantia firme dessa segurança parecem ser (i) a grande margem de discricionariedade permitida pelo legislador e o uso que dela fez o regulador em sua espécie geral, isto é, a ANEEL por meio da edição da REN nº 63/2004; (ii) a também grande margem de discricionariedade permitida pela própria REN no 63/2004 e o uso que dela fazem as Superintendências de Fiscalização e as Agências Estaduais conveniadas, com o significativo uso de critérios subjetivos, e com pouca publicidade e uniformidade em suas práticas. 


\section{PROPOSTAS}

Este Capítulo apresenta propostas que visam solucionar ou ao menos mitigar os problemas apontados nas considerações feitas no Capítulo 9.

As ideias gerais que permeiam as propostas apresentadas são a simplificação do processo, a diminuição do uso da discricionariedade específica em favor da discricionariedade geral, e a exigência de publicidade e da maior objetividade possível na aplicação da norma pelas Superintendências de Fiscalização da ANEEL e pelas Agências Estaduais.

\subsection{Sobre a tipificação das infrações}

Em oposição à tipificação detalhada empregada pela ANEEL, que resulta atualmente em total de cento e trinta tipos, sugere-se que melhor seria classificar as infrações em poucos (talvez uma dezena ou duas) e amplos tipos. Poucos o suficiente para deixar clara a hierarquia entre eles e amplos o suficiente para conter, em conjunto, no mínimo as infrações já tipificadas na norma atual, mas que, justamente por sua amplitude, teriam uma chance maior de englobar também as inevitáveis situações ainda não enfrentadas pelo regulador e pelas empresas, isto é, as condutas eventualmente entendidas como infração administrativa, mas que ainda não estão descritas na REN nº 63/2004.

Entende-se que a situação proposta, não obstante a perda em detalhamento, traria ganhos em simplicidade, atributo essencial de uma boa norma. Se bem especificados os tipos, e bem diferenciados uns dos outros, essa simplicidade se traduziria em segurança jurídica às empresas, uma vez que, além de depararem-se com uma regulamentação mais simples, que se permite ser compreendida como um todo, não teriam dúvida quanto às penalidades a que estão sujeitas em decorrências das diversas infrações.

Em um ambiente em que é garantida legalmente ao regulador a discricionariedade na definição dos tipos de infração, não há por que esse "exagerar" na diferenciação entre os elementos. Mais vale zelar pela simplicidade, como forma de garantir a plena discussão e, portanto, o direito à ampla defesa e ao contraditório descritos na Lei $n^{\circ} 9.784 / 1999$, sobre as decisões que são fruto dessa discricionariedade. 
Do ponto de vista do direito administrativo sancionador, Vieira (2010), ao discorrer sobre infrações e penalidades em contratação com a administração pública no âmbito da Lei $n^{\circ} 8.666 / 1993$, lembra que

As pessoas que firmam contratos com a Administração Pública têm direito de saber quais as consequências que podem surgir de seus atos. Tem direito à informação clara e transparente, bem como à segurança jurídica.

$[\ldots]$

Na prática, também seria inviável um rol delimitado de infrações administrativas, o qual certamente não conseguiria prever todas as situações de descumprimento de contrato na imensa variedade existente de contratos administrativos.

Para Bandeira de Mello (1979), o direito disciplinar não exige a definição específica, taxativa, da falta administrativa.

E segundo Fábio Medina Osório (2000), o tipo sancionador deve possuir um grau mínimo de certeza e previsibilidade.

Desse modo, vê-se que a simplificação dos tipos descritos na REN n 63/2004 não inovaria nem contrariaria a boa prática do direito administrativo.

Logicamente, a definição desses tipos amplos precisaria ser objeto de um estudo específico sobre as afinidades entre as infrações, objetivo ao qual este trabalho não se propõe.

Adicionalmente, uma vez que a tipificação da infração consiste em "enquadrá-la" em uma categoria abstrata que remeta a uma sanção correspondente, propõe-se que a norma deixe claro em seu texto que a própria ação de tipificar seja compreendida como a definição da "natureza" da infração, critério cuja consideração é exigida pelo Decreto n 2.335/1996 para o estabelecimento de sanções administrativas. Conforme exposto no Capítulo 9, é isso que se interpreta no atual texto da REN nº 63/2004, que, no entanto, não contém explicitamente essa informação.

\subsection{Sobre os grupos de infrações e os valores máximos das multas}

Sugere-se que o primeiro grupo de infrações punidas com multa pecuniária tenha um valor máximo em relação ao faturamento da empresa mais significativo. Assim ficaria clara às empresas a distinção que a ANEEL faz entre os dois tipos de infração, as puníveis com advertência e as puníveis com multa. 
Desse modo, são propostos limites alternativos para o valor máximo das multas aplicáveis pela ANEEL, com "degraus" menores entre si e maiores em relação à penalidade de advertência, conforme figura que segue.

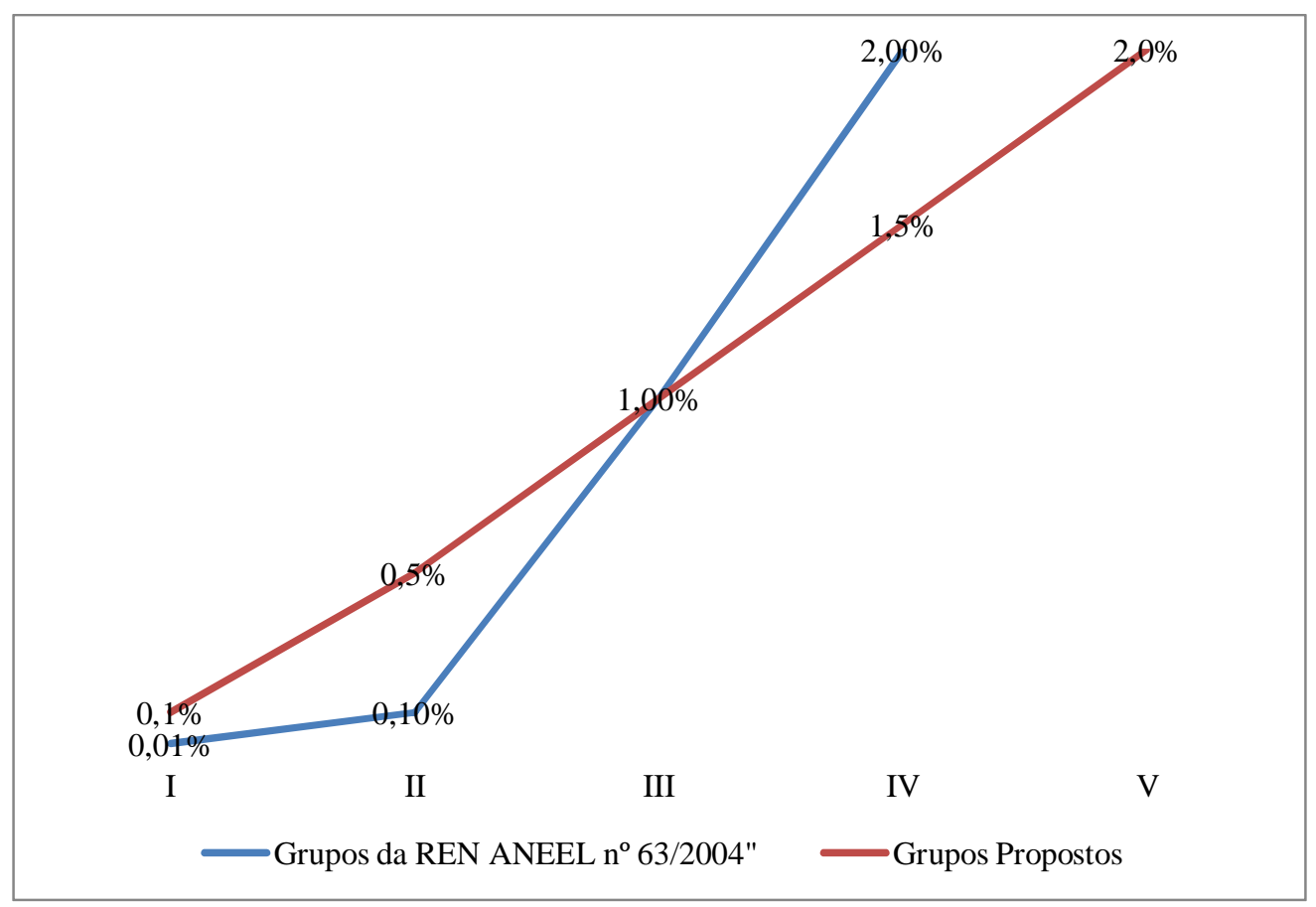

Figura 10.1 - Valores máximos das multas por grupo (\% do faturamento anual da empresa autuada) Fonte: Elaboração própria

Nessa proposta são definidos cinco grupos. As infrações compreendidas no primeiro deles (grupo I) seriam objeto de penalidade de valor máximo correspondente a $0,1 \%$ do faturamento anual da empresa autuada, já as compreendidas no último (grupo V), $2 \%$ desse montante, ou seja, o valor máximo permitido pela Lei n ${ }^{\circ}$ 9.427/1996.

A proporção entre o menor e o maior grupo de valores máximos de multas seria de vinte vezes, dez vezes menor que o disposto na atual regulamentação. Esse intervalo parece ser plenamente suficiente para garantir ao regulador o exercício de discricionariedade na aplicação de sanções, bem como para sinalizar ao mercado a hierarquia de gravidade entre as infrações.

Cabe observar que os valores propostos para os limites são ilustrativos, sendo que ajustes podem ser feitos posteriormente ao necessário estudo da classificação das infrações em tipos gerais. A essência da proposta consiste em um conjunto de grupos que preserve, 
aproximadamente, a proporção sugerida entre seus elementos (de no máximo cinco vezes entre grupos subjacentes e de no máximo vinte vezes entre o primeiro e o último), e que sinalize claramente a diferença entre as infrações punidas com advertência e as punidas com multa.

Analogamente ao proposto para a consideração do critério "natureza", propõe-se que a norma, ao alocar os tipos infracionais em grupos de valores máximos de multa (ou de advertência), deixe claro que essa ação corresponde à consideração do critério "gravidade", conforme exigido pelo Decreto $n^{\circ}$ 2.335/1996 para o estabelecimento de sanções administrativas. Assim, pretende-se resolver o problema da dupla consideração da gravidade, apontado no Capítulo 9.

\subsection{Sobre os critérios considerados}

A proposta sobre os critérios que devem ser utilizados baseia-se também na simplicidade: usar o menor número possível de critérios - três (natureza, gravidade e reincidência) são exigidos pelo Decreto $n^{\circ} 2.335 / 1996$ - que seja suficiente para permitir o exercício da discricionariedade em seus dois níveis. Ou seja, utilizar o mínimo de critérios que permita o atendimento aos princípios da isonomia e da segurança jurídica, concomitantemente aos da adequação e da individualização das sanções.

Conforme exposto nas duas seções imediatamente anteriores, a natureza e a gravidade seriam consideradas, respectivamente, na tipificação da infração e na alocação do tipo no adequado grupo de penalidade. Dessa forma, dois dos critérios descritos no Decreto $\mathrm{n}^{\circ}$ 2.335/1996 seriam objeto exclusivamente de discricionariedade geral e garantiriam, portanto, respeito à segurança jurídica e ao tratamento isonômico entre as empresas.

Cogita-se, no entanto, que avaliar unicamente a condição de reincidência da empresa infratora, que é o terceiro critério exigido pelo Decreto, pode não ser suficiente para que as autoridades que lavram os autos de infração exercitem satisfatoriamente a discricionariedade específica, ou seja, para que promovam a adequação e a individualização das sanções que impõem.

Por isso, propõe-se que, assim como descreve o texto atual da REN n 63/2004, sejam considerados os critérios adicionais de "danos" (causados ao serviço ou aos usuários), e "vantagens" (auferidas pela empresa pela prática da infração), além da reincidência da 
empresa. Esses dois critérios adicionais podem ser entendidos como termos de abrandamento ou agravamento da "gravidade" definida para a sanção.

Assim, os critérios que se propõe que sejam considerados para a definição das sanções aplicadas pela ANEEL às empresas por ela reguladas são: natureza e gravidade, sujeitos à discricionariedade geral e; danos, vantagens e reincidência, sujeitos à discricionariedade específica.

\subsection{Sobre a forma de consideração dos critérios}

Sugere-se que sejam definidas pela norma as parcelas da multa que devem ser estabelecidas tomando-se por base a avaliação de cada um dos critérios considerados, dentro do valor máximo permitido para o grupo de tipos da infração.

Por essa ideia, o valor total da penalidade permitido para o grupo é compartimentado em parcelas que são, cada uma delas, definidas por um dos critérios considerados. Uma das parcelas não está relacionada a nenhum critério, exceto aos nesse ponto já avaliados "natureza" e "gravidade", que são objeto de discricionariedade geral. Essa parcela corresponde ao "núcleo duro" da sanção, e constitui o valor mínimo de multa aplicado para infrações do grupo.

A figura a seguir exemplifica essa ideia.

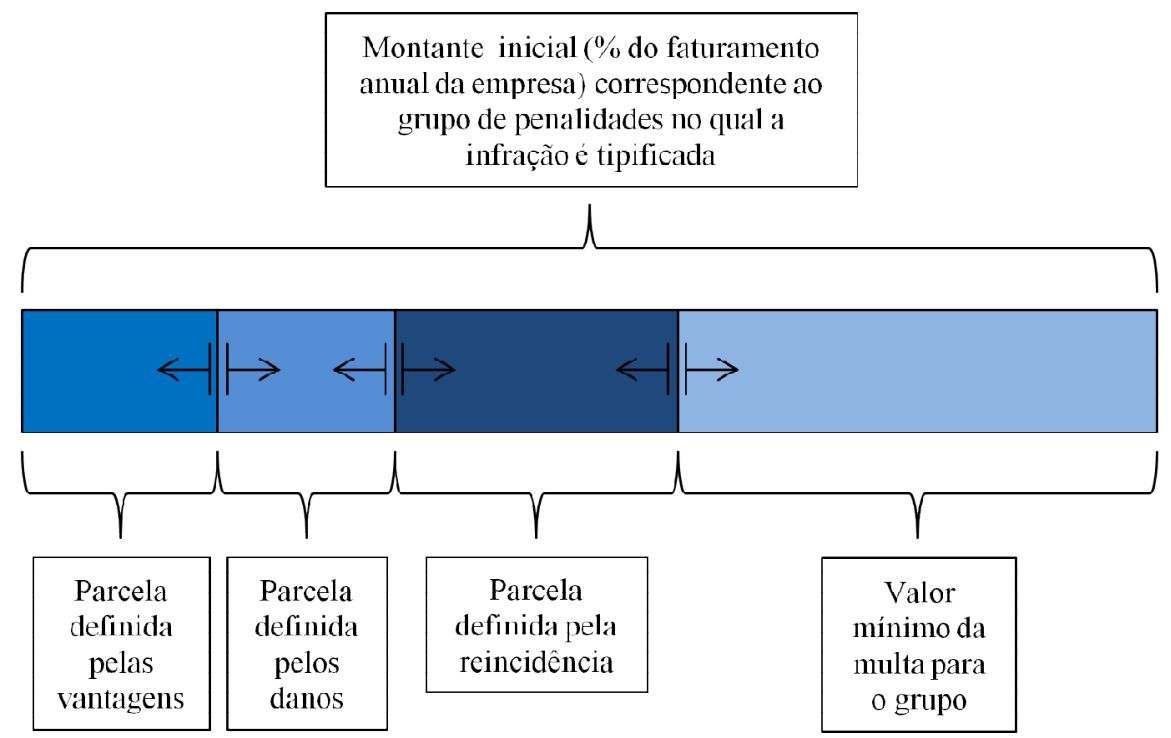

Figura 10.2 - Valor máximo da multa dividido em parcelas que são definidas pela consideração de cada critério

Fonte: Elaboração própria 
Ou seja, caberia às autoridades que instruem o processo punitivo decidir, para cada uma das parcelas estabelecidas na norma, a dosimetria utilizada no caso concreto, com exceção do "núcleo duro", cuja dosimetria seria definida pela própria tipificação da infração.

Essa ideia é exemplificada na figura que segue.

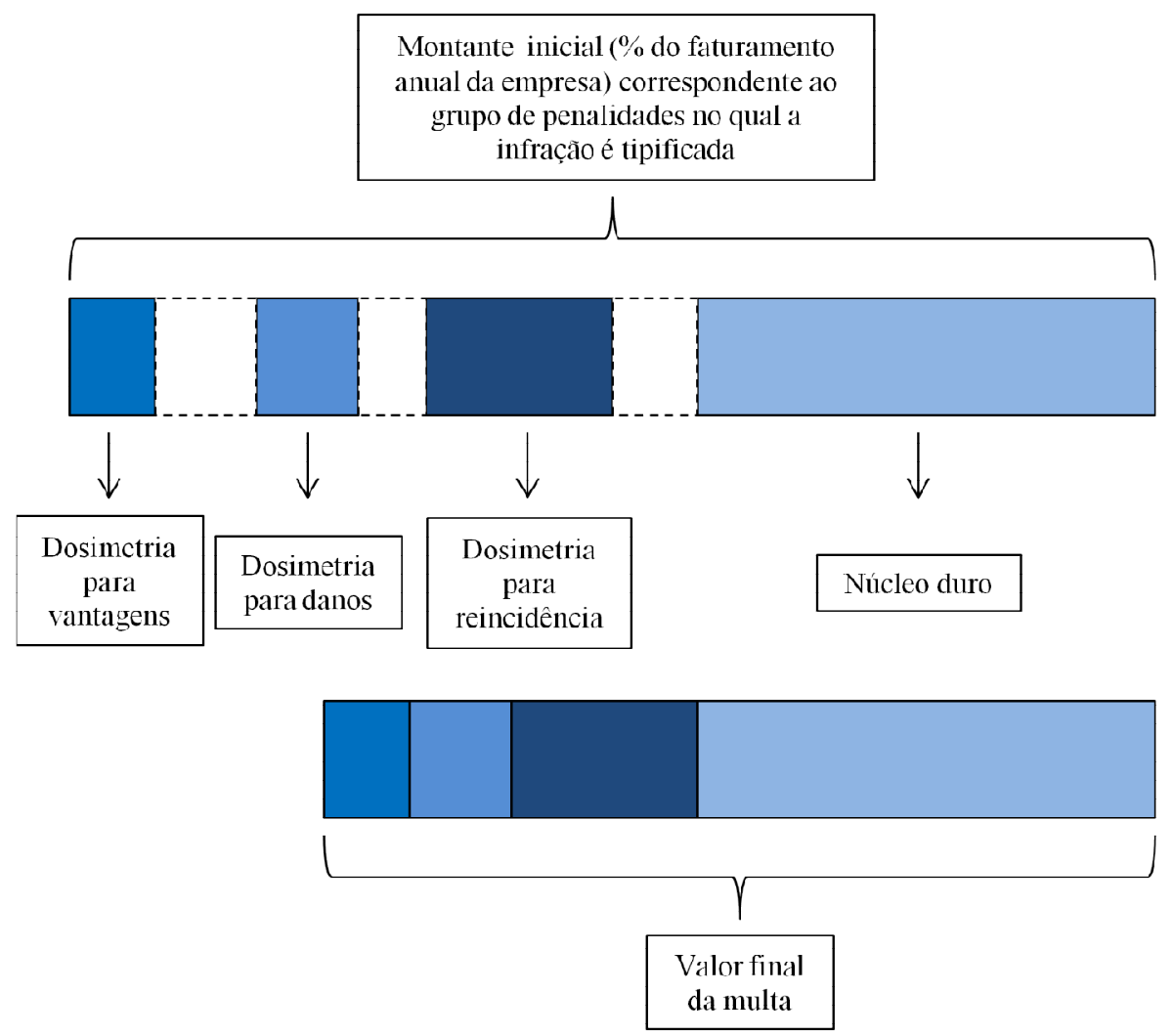

Figura 10.3 - Exemplo de multa estabelecida por parcelas correspondentes aos critérios

Fonte: Elaboração própria

Os critérios cuja consideração (dentro dos limites de cada compartimento) se sugere que fiquem à mercê de definição das autoridades que impõem as sanções (discricionariedade específica) são aqueles que podemos chamar de "conjunturais", e que, portanto, têm melhor condição de serem avaliados por quem pode considerar a conjuntura do caso concreto. De fato, os danos e as vantagens causadas pela infração, assim como a condição de reincidência ${ }^{31}$ da empresa só podem ser avaliados caso a caso, enquanto a natureza e a gravidade da infração podem ser entendidas como aspectos inerentes à própria infração. ${ }^{31}$ O critério "reincidência" pode considerar conjuntamente as reincidências "geral" e "específica", conforme
definições feitas no Capítulo 9. 
Assim, a maneira que se sugere para consideração dos critérios na composição do valor final das multas aplicadas pela ANEEL é a descrita no diagrama da Figura 10.4, que também mostra em que pontos são exercidas as discricionariedades "geral" e "específica".

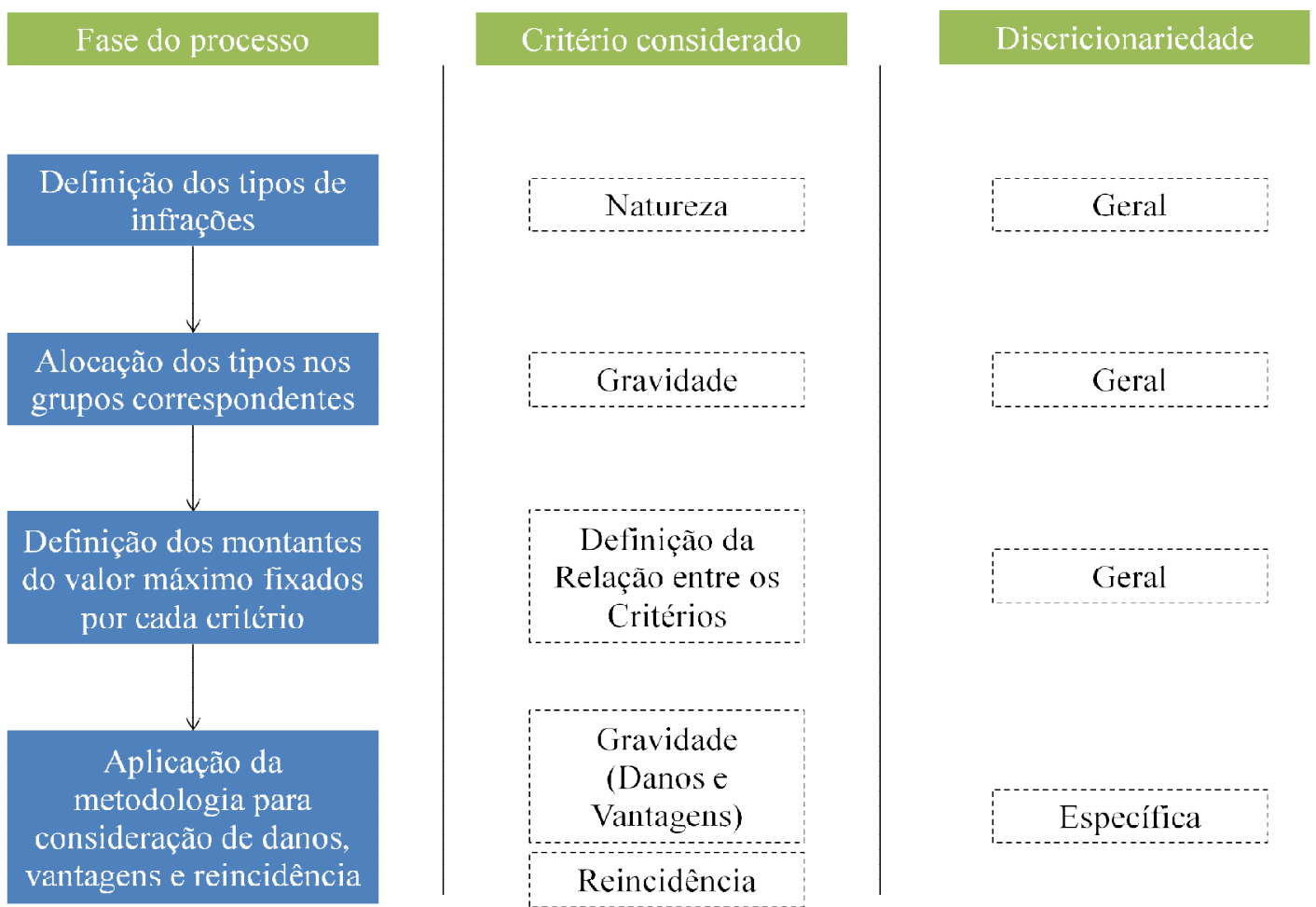

Figura 10.4 - Proposta para composição do valor das multas aplicadas pela ANEEL

Fonte: Elaboração própria

Considera-se que a presente proposta estabelece uma relação de equilíbrio entre as discricionariedades "geral" e "específica", e por isso, o atendimento concomitante aos princípios da isonomia, da segurança jurídica, da adequação e da individualização das sanções.

\subsection{Sobre os procedimentos de fiscalização e aplicação de penalidades}

Sugere-se que seja elaborada pela ANEEL uma resolução normativa específica com o objetivo de regulamentar o processo de fiscalização em suas partes não encampadas pela REN $n^{\circ}$ 63/2004. Ou mesmo que essa regulamentação seja feita na mesma norma que disciplina o 
processo punitivo. Essa regulamentação deve descrever as diretrizes e princípios que regem a ação fiscalizadora da ANEEL; conter as fases do planejamento de fiscalização, com as aprovações necessárias da Diretoria da Agência e os adequados instrumentos de publicidade; os procedimentos e meios $\operatorname{adotados}^{32}$ pelas Superintendências na execução das ações e; especificar os produtos (relatórios periódicos) que devem ser publicados como forma de prestação de contas das atividades realizadas.

Essas definições objetivam esclarecer às empresas reguladas e à sociedade a execução das atividades de fiscalização. Entende-se como de essencial importância a publicação periódica de relatórios de resultados, pois, além de terem grande poder de esclarecimento, ampliam os efeitos das sanções aplicadas, tanto no sentido de "expor" e "constranger" a empresa apenada como no de dissuadir as demais de incorrerem em infração semelhante.

Faz-se necessário ainda que a norma que discipline a imposição de sanções exija das Superintendências de Fiscalização da ANEEL a definição e a publicação de seus métodos de cálculo da dosimetria das multas que aplicam (dosimetria para danos, vantagens e reincidência). Essa definição e publicidade das metodologias devem ser feitas por meio de instrumentos que possam ser alterados a qualquer momento por essas mesmas Superintendências, ficando assim garantido o exercício de sua discricionariedade.

A Figura 10.5 que segue ilustra essas ideias.

\footnotetext{
32 Por "procedimentos e meios" se entende a descrição geral de cada atividade específica de fiscalização realizada pelas Superintendências, e não a sua descrição completa e detalhada. Essa descrição geral, que se defende que seja publicada, tem por objetivo esclarecer às empresas e à sociedade a maneira como trabalha a fiscalização da ANEEL. Entende-se que não seria útil ao cumprimento dos objetivos da Agência a publicação das metodologias de fiscalização propriamente ditas, pois, o conhecimento, por parte das empresas fiscalizadas, das práticas detalhadas poderia possibilitar que buscassem "brechas" nos procedimentos, ou seja, que direcionassem seus esforços ao atendimento das expectativas das equipes de fiscalização e não à busca da qualidade do serviço. Essa possibilidade excluiria o "elemento surpresa" da fiscalização e, opina-se, diminuiria sua eficácia.
} 


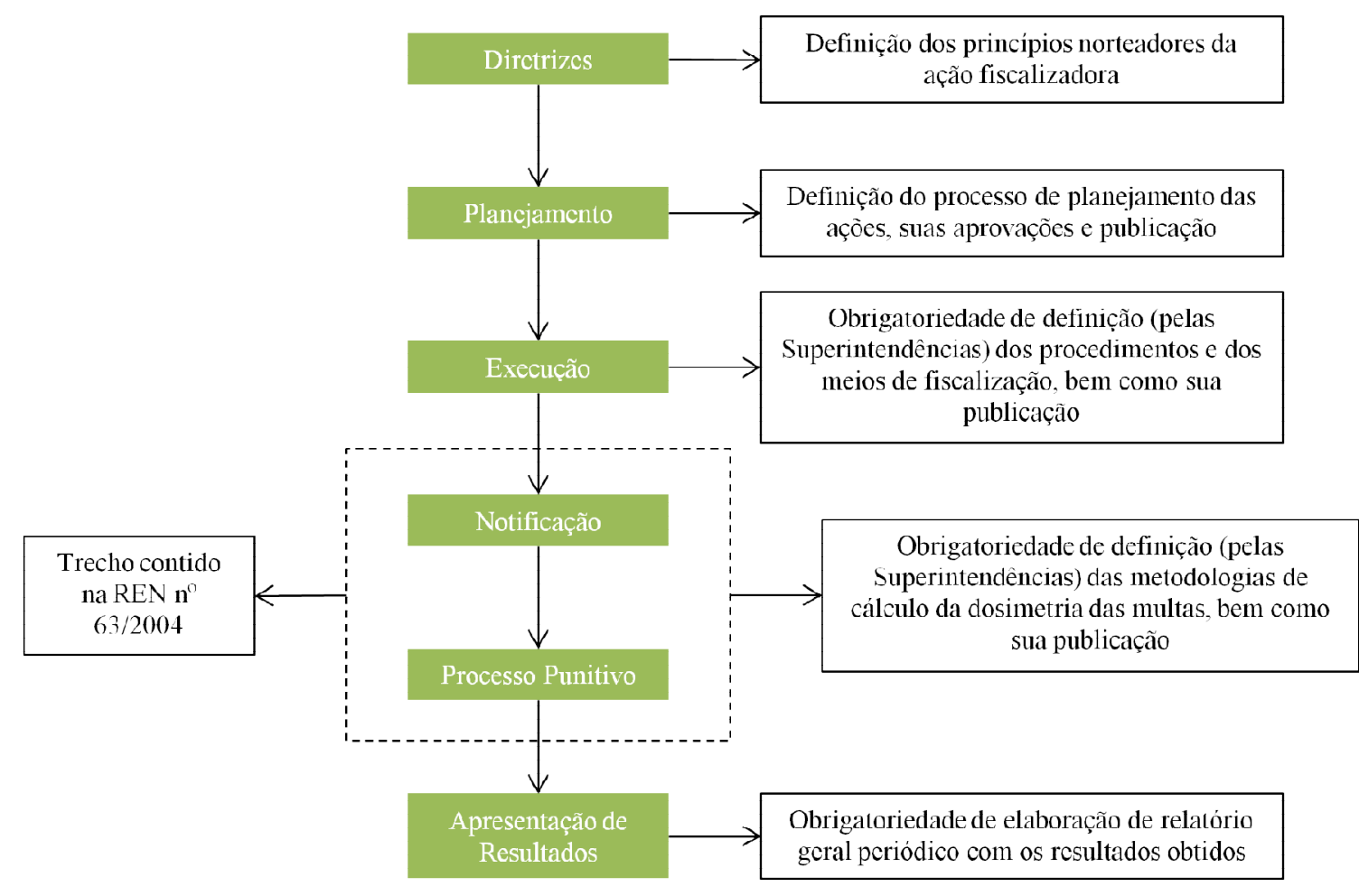

Figura 10.5 - Visão geral do processo de fiscalização

Fonte: Elaboração própria

Entende-se que essas definições têm o poder de trazer maior clareza e legitimidade para as empresas reguladas e para a sociedade sobre o processo de fiscalização e de aplicação de penalidades da ANEEL.

\subsection{Resumo da proposta}

Sugere-se uma alternativa à REN no 63/2004, com aumento do uso da discricionariedade geral (exercida pela Diretoria no momento de elaboração da norma) em detrimento do uso da discricionariedade específica (efetuada pela autoridade que lavra o auto de infração no caso concreto).

Como dito, a proposta tem seu foco principal na simplicidade do procedimento de imposição de sanções, apoiada na premissa de que essa simplicidade, ao mesmo tempo em que não impede o regulador de exercer a discricionariedade que legalmente lhe compete, torna o processo menos "impenetrável" ao entendimento da sociedade e das empresas 
reguladas, garantindo às autuadas o pleno exercício de seus direitos de ampla defesa e contraditório, previstos na Lei nº 9.784/1999.

Desse modo propõe-se um método alternativo para a tipificação das infrações, para escalonamento das sanções em grupos de valores máximos e para a consideração dos critérios de gradação das multas.

Propõe-se também que a relação entre os critérios considerados na composição da multa seja estabelecida pela norma, bem como que a norma exija das Superintendências de Fiscalização a definição e a publicação de seus procedimentos para cálculo da dosimetria das multas, com o máximo de objetividade possível.

Por fim, sugere-se a elaboração de uma norma (ou uma expansão do escopo da REN $n^{\circ}$ 63/2004) que discipline os trechos do processo de fiscalização não regulamentados na norma atual: diretrizes, planejamento, execução e apresentação de resultados. Considera-se que essas definições tem o condão de informar às empresas e à sociedade as atividades desempenhadas pela estrutura de fiscalização da ANEEL. Entende-se ainda que a apresentação dos resultados da fiscalização em relatórios periódicos amplia os efeitos dissuasório e retributivo das sanções aplicadas, uma vez que as divulga para o mercado regulado e "expõe" a empresa apenada.

O diagrama que segue compara, nesses aspectos, a regulamentação vigente e a proposta. 


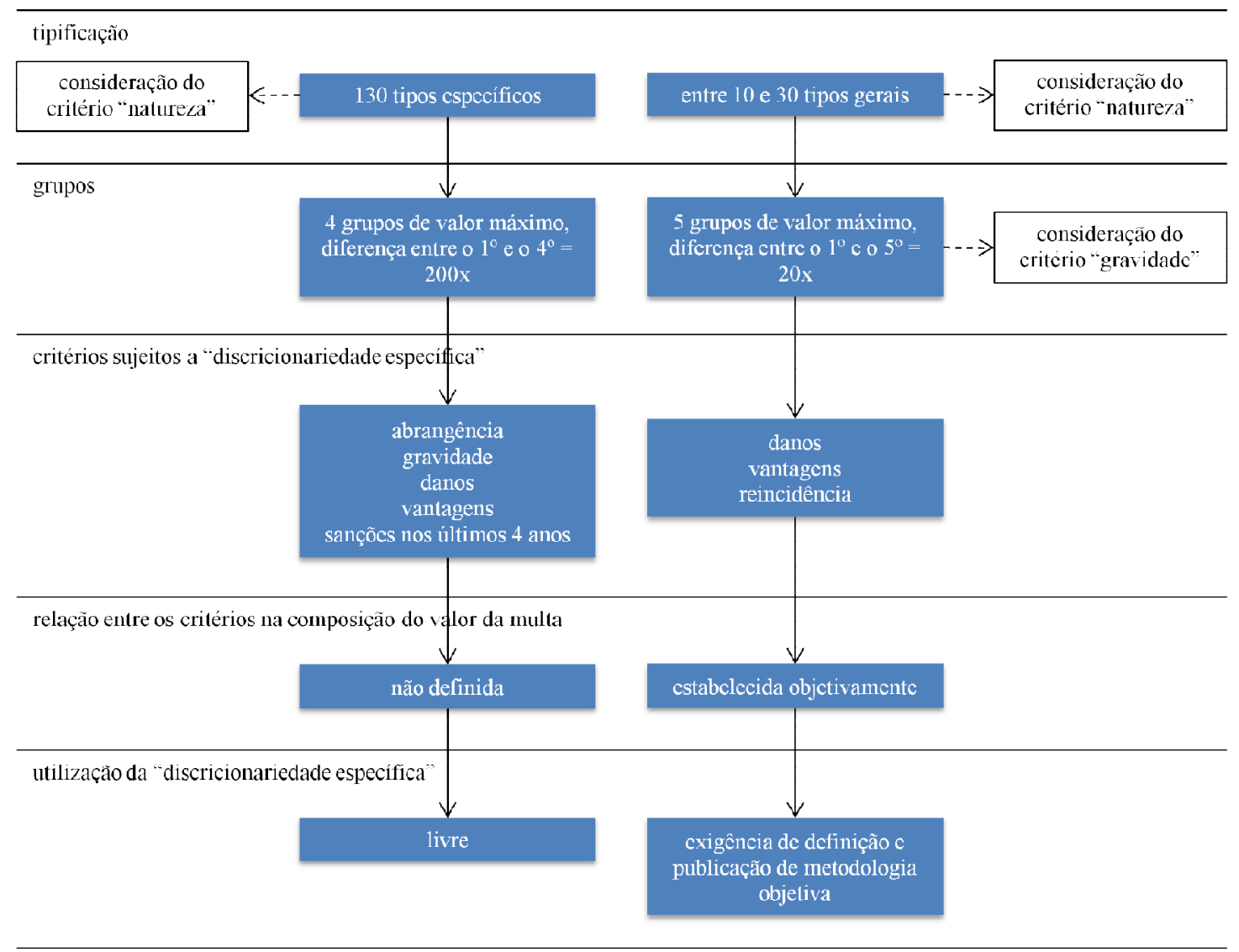

trechos do processo não contidos na REN 11' 63/2004

dirctrizcs, plancjamcnto,

exceução c apresentação dos

resultados da fiscalização

Figura 10.6 - Comparação entre a regulamentação vigente e a proposta

Fonte: Elaboração própria

A reformulação da REN no 63/2004 nos termos propostos pode colocar-se como um meio eficaz para uma efetiva melhoria no processo de imposição de sanções no setor elétrico. A simplicidade que se espera conseguir com a solução proposta tem o objetivo de aumentar a segurança jurídica no setor e a transparência no exercício da competência fiscalizadora da ANEEL.

É razoável supor que, além das vantagens geradas para as empresas reguladas, essa simplificação pode significar um menor custo processual para a ANEEL e para as Agências Estaduais na instauração de processos administrativos punitivos. 


\section{CONCLUSÕES}

Conclui-se que entre os esforços da ANEEL para garantir o atendimento aos princípios constitucionais da proporcionalidade e da individualização das sanções e, concomitantemente, aos princípios da isonomia e da segurança jurídica em seus processos punitivos, há um desequilíbrio em desfavor dos dois últimos.

Os principais problemas para a garantia firme da isonomia e da segurança jurídica no processo de fiscalização e imposição de sanções às empresas que atuam no setor elétrico brasileiro parecem ser a grande margem de discricionariedade permitida pelo legislador na Lei $n^{\circ} 9.427$, de 26 de dezembro de 1996 e no Decreto $n^{\circ} 2.335$, de 6 de outubro de 1997, bem como o uso que dela fez a ANEEL por meio da edição da Resolução Normativa $n^{\circ}$ 63, de 12 de maio de 2004, que permitiu que ainda restasse à decisão do corpo técnico da Agência uma significativa parcela dessa discricionariedade. Esse corpo técnico, formado por três Superintendências de Fiscalização, ao menos uma dezena de Agências Estaduais conveniadas e pela própria Diretoria da ANEEL, tem dificuldade em lidar de forma simples e objetiva com tamanho poder discricionário.

A principal conclusão é que esses problemas podem ser solucionados, ou ao menos mitigados pela Agência, por meio de aprimoramentos em sua regulamentação.

Esses aprimoramentos podem ser efetuados na REN nº 63/2004 na tipificação das infrações, na definição dos grupos de infrações e seus respectivos valores máximos permitidos para a imposição de penalidades, na disposição dos critérios utilizados para quantificação das penalidades e na definição do rito adotado para sua imposição às empresas. Outro aprimoramento pode ser feito pela ampliação do escopo da norma, que passaria a trazer definições sobre todo o processo de fiscalização.

Essas alterações têm seu foco principal na simplicidade dos procedimentos, tornandoos mais acessíveis ao entendimento da sociedade e das empresas reguladas. Elas significam um aumento do exercício da discricionariedade geral (exercida pela Diretoria da ANEEL no momento de elaboração ou revisão da norma) em detrimento da utilização da discricionariedade específica (efetuada pelo corpo técnico da Agência no caso concreto). Essas alterações significam também a exigência de maiores publicidade e objetividade na condução dos processos de fiscalização e imposição de penalidades. 
Finalmente, conclui-se que as ideias apresentadas têm o condão de colaborar com a ANEEL no cumprimento de sua missão, por meio da criação de uma regulamentação capaz de contribuir com a obtenção de um sistema sancionador eficaz e que preze pela segurança jurídica e pela a transparência. 


\section{BIBLIOGRAFIA}

1. ABRADEE. Visão Geral do Setor. Disponível em http://www.abradee.com.br/setor-eletrico/visao-geral-do-setor. Acesso em novembro de 2013.

2.

A Tarifa de Energia. Disponível em http://www.abradee.com.br/setor-dedistribuicao/tarifas-de-energia/tarifas-de-energia. Acesso em novembro de 2013.

3. ANEEL. Informações Técnicas. Disponível em http://www.aneel.gov.br/areaPerfil.cfm?idPerfil=2. Acesso em novembro de 2013.

4. . Nota Técnica no 39/2010-SFE/ANEEL, de 15 de junho de 2010.

5. Nota Técnica no 384/2012-SFF/ANEEL, de 08 de outubro de 2012.

6. Parecer no 0697/2011/PGE-ANEEL/PGF/AGU, de 31 de outubro de 2011.

7. Processos Administrativos 48500.002825/2012-14, 48500.002945/201201， 48500.002022/2004-42，48500.005060/2006-18， 48500.003858/2005-72 e 48500.000181/2013-92. Disponíveis em http://www.aneel.gov.br/aplicacoes/documentosFiscalizacao/. Acessos entre novembro e dezembro de 2013.

8. ___ Resolução Normativa $\mathbf{n}^{\mathbf{0}}$ 63, de 12 de maio de 2004. Disponível em http://www.aneel.gov.br/cedoc/ren2004063.pdf.

9. ___ Resolução Normativa $\mathbf{n}^{\mathbf{0}} \mathbf{3 3 3}$, de 7 de outubro de 2008. Disponível em http://www.aneel.gov.br/cedoc/ren2008333.pdf.

10. ___ Resolução Normativa $\mathbf{n}^{\mathbf{0}}$ 417, de 23 de novembro de 2010. Disponível em http://www.aneel.gov.br/cedoc/ren2010417.pdf.

11. ___ Resolução Normativa $\mathbf{n}^{\mathbf{0}}$ 540, de 12 de março de 2013. Disponível em http://www.aneel.gov.br/cedoc/ren2013540.pdf.

12. AlbUQUERQUE, Álvaro Rocha. Fluxo de Caixa em Risco: Uma Nova Abordagem para o Setor de Distribuição de Energia Elétrica. Dissertação de 
Mestrado, Departamento de Engenharia Elétrica da Pontifícia Universidade Católica do Rio de Janeiro, Rio de Janeiro, 2008.

13. ANDRADE, Fabrício. O que é Segurança Jurídica. Professor Fabrício Andrade, 2010. Disponível em http://professorfabricioandrade.blogspot.com.br/2010/04/o-quee-seguranca-juridica.html.

14. ARAGÃO, Alexandre Santos de. Agências Reguladoras e a Evolução do Direito Administrativo Econômico. Forense, Rio de Janeiro, 2002.

15. BARSTAD, Adriana Baroni Santi; COSTA, Luciana Pereira; SADER, Marcos. Isonomia e Individualização da Pena não se Excluem. Consultor Jurídico, 2010. Disponível em http://www.conjur.com.br/2010-set-02/isonomia-individualizacaopena-nao-sao-excludentes-entre-si.

16. BRASIL. Constituição Federal, de 5 de outubro de 1988. Atualizada com as Emendas Constitucionais $\quad$ Promulgadas. Disponível em http://www.planalto.gov.br/ccivil 03/constituicao/constituicao.htm.

17.___ Lei $\mathbf{n}^{\mathbf{0}} \mathbf{6 . 3 8 5}$, de 7 de dezembro de 1976. Disponível em http://www.planalto.gov.br/ccivil 03/leis/16385.htm.

18. . Lei $\mathbf{n}^{\mathbf{0}}$ 8.666, de 21 de junho de 1993. Disponível em http://www.planalto.gov.br/ccivil_03/leis/18666cons.htm.

19. Lei $\mathbf{n}^{\mathbf{0}}$ 8.987, de 13 de fevereiro de 1995. Disponível em http://www.planalto.gov.br/ccivil 03/leis/18987cons.htm.

20. ___ Lei $\mathbf{n}^{\mathbf{0}} \mathbf{9 . 4 2 7}$, de 26 de dezembro de 1996. Disponível em http://www.planalto.gov.br/ccivil_03/leis/L9427cons.htm.

21.____ Lei $\mathbf{n}^{\mathbf{0}} \mathbf{9 . 7 8 4}$, de 29 de janeiro de 1999. Disponível em http://www.planalto.gov.br/ccivil_03/leis/L9784.htm.

22. ___ Lei $\mathbf{n}^{\mathbf{0}} \mathbf{1 0 . 8 4 8}$, de 15 de março de 2004. Disponível em http://www.planalto.gov.br/ccivil_03/_ato2004-2006/2004/lei/110.848.HTM.

23. Decreto $\mathbf{n}^{\mathbf{0}}$ 2.335, de 06 de outubro de 1997. Disponível em http://www.planalto.gov.br/ccivil_03/decreto/d2335.HTM.

24. BANDEIRA DE MELlO, Celso Antônio. Curso de Direito Administrativo. 29a ed., Malheiros, São Paulo, 2012. 
25. BANDEIRA DE MELlO, Oswaldo Aranha. Princípios Gerais de Direito Administrativo. V.2, Forense, Rio de Janeiro, 1979.

26. BECCARIA, Cesare. Dos Delitos e das Penas. Tradução de Guidinici, L. e Contessa, A. B. $3^{\text {a }}$ ed. Martins Fontes, São Paulo, 2005.

27. BITTENCOURT, Marcus Vinicius Corrêa. Controle das Concessões de Serviço Público. Forum, Belo Horizonte, 2006.

28. BORGES, Gustavo Gonçalves. Sistema de Apoio à Fiscalização das Concessionárias de Distribuição de Energia Elétrica. Dissertação de Mestrado, Escola Politécnica da Universidade de São Paulo, São Paulo, 2005.

29. BOSCHI, José Antonio Paganella. Das Penas e seus Critérios de Aplicação. $6^{\text {a }}$ ed. Livraria do Advogado, Porto Alegre, 2013.

30. CARVAlho Neto, Inácio de. Aplicação da Pena. $3^{a}$ ed., Método, São Paulo, 2008 .

31. CASTRO, Nivalde J. de; BRANDÃO, Roberto; OZÓRIO, Luiz. O Desempenho Financeiro das Distribuidoras de Energia Elétrica e o Processo de Revisão Tarifária Periódica. Texto de Discussão do Setor Elétrico nº 34, Grupo de Estudos do Setor Elétrico - GESEL da Universidade Federal do Rio de Janeiro - UFRJ, Rio de Janeiro, 2011.

32. CCEE. Infomercado, $\mathrm{n}^{\mathrm{o}} 75$ - Novembro/2013. Disponível em http://www.ccee.org.br/portal/faces/pages_publico/quemsomos/informacoesmercado/info mercado? afrLoop $=1059764543605000 \# \% 40 \% 3 \mathrm{~F}$ _afrLoop\%3D1059764543605000\%26_adf.ctrl-state\%3Drbslwj2tl_17. Acesso em novembro de 2013.

33. DAL POZZO, Augusto Neves. Aspectos Fundamentais do Serviço Público no Direito Brasileiro. Malheiros, São Paulo, 2012.

34. DI PIETRO, Maria Sylvia Zanella. Discricionariedade Técnica e Discricionariedade Administrativa. In: Redae, Número 9, Salvador, 2007. Disponível em http://www.direitodoestado.com/revista/REDAE-9-FEVEREIRO2007-MARIA\%20SYLVIA.pdf.

35. Parcerias na Administração Pública. Atlas, São Paulo, 1999. 
36. DIOS, Laureano Canabarro. Princípio Constitucional da Individualização da Pena no Âmbito do Tribunal de Contas da União. Monografia, TCU, Brasília, 2006.

37. FARIA, Margarida Ermelinda Lima de Morais. O Sistema das Sanções e os Princípios do Direito Administrativo Sancionador. Dissertação de Mestrado, Secção Autónoma de Ciências Sociais, Jurídicas e Políticas da Universidade de Aveiro, Aveiro, 2007.

38. FERRAZ JÚNIOR, Tércio Sampaio. Introdução ao Estudo do Direito: Técnica, Decisão, Dominação. Atlas, São Paulo, 2008.

39. GHIRARDI, André G. A Presença da Agência Reguladora Estadual e a Qualidade dos Serviços de Distribuição de Energia Elétrica. In: Anais... I Congresso Brasileiro de Regulação de Serviços Públicos Concedidos, Salvador, 2000.

40. MARQUES NETO, Discricionariedade e Regulação Setorial - O Caso do Controle dos Atos de Concentração por Regulador Setorial, in ARAGÃO, Alexandre Santos de. (Org.). O Poder Normativo das Agências Reguladoras. Forense, Rio de Janeiro, 2006.

41. MARTINS, Juliana Nogueira Galvão. Tipicidade: Conceito e Classificação. In: Conteúdo Jurídico, 2008. Disponível em http://conteudojuridico.com.br/?artigos\&ver=2.22427.

42. MEDINA OSÓRIO, Fábio. Direito Administrativo Sancionador. Revista dos Tribunais, São Paulo, 2000.

43. MELlo, Rafael Munhoz de. Princípios Constitucionais de Direito Administrativo Sancionador. As Sanções Administrativas à Luz da Constituição Federal de 1988. Malheiros, São Paulo, 2007.

44. MME. Portaria $\mathbf{n}^{\mathbf{0}}$ 349, de 28 de novembro de 1997. Disponível em http://www.aneel.gov.br/cedoc/bprt1997349mme.pdf.

45. ___ Plano Decenal de Expansão de Energia 2020. Novembro de 2011. Disponível em http://www.mme.gov.br/mme/galerias/arquivos/publicacoes/PDE_2019/PDE2020RELATORIO.pdf. 
46. MODESTO, Paulo. Autovinculação da Administração Pública. In: Redae, Número 24, $\quad$ Salvador, 2010. Disponível em http://www.direitodoestado.com/revista/REDE-24-OUTUBRO-2010-PAULOMODESTO.pdf.

47. MOREIRA, N. H. Perspectivas da Matriz Energética Brasileira. Apresentação. In: Ciclo de Palestras de Furnas, 2008.

48. MOREIRA, Vital. Auto-regulação Profissional e Administração Pública. Almedina, Coimbra, 1997.

49. MOREIRA PINTO, Gabriel. A Dosimetria das Multas Impostas em Resposta às Infrações Contra a Ordem Econômica: uma análise da Lei de Defesa da Concorrência e de sua aplicação pelo CADE. Monografia de Graduação, Universidade de São Paulo, São Paulo, 2010.

50. O GLOBO. Comparação entre as Usinas Jirau e Santo Antonio. Infográfico, sem data. Disponível em http://oglobo.globo.com/infograficos/usinas-jirau-santoantonio/. Acesso em novembro de 2013.

51. ONS. O que é o SIN - Sistema Interligado Nacional. Disponível em http://www.ons.org.br/conheca_sistema/o_que_e_sin.aspx. Acesso em novembro de 2013.

52. Procedimentos de Rede, Módulo 26: Modalidade de Operação de Usinas. Disponível em http://extranet.ons.org.br/operacao/EventosPR.nsf/principalweb?openframeset. Acesso em novembro de 2013.

53. PAGLIARDI, Odail \& SOBREIRO DIAS, José Celso. Evolução Do Setor Elétrico: Uma Breve Reflexão. In: Interciência e Sociedade. V.1, $n^{\circ} 1$ (2011). Faculdade Municipal Professor Franco Montoro, Mogi Guaçu, 2011.

54. PORTAL BRASIL. Energia Produzida em Rondônia Chega ao Sudeste. Reportagem, 2011. Disponível em http://www.brasil.gov.br/infraestrutura/2011/12/energia-produzida-em-rondoniachega-ao-sudeste. Acesso em novembro de 2013.

55. REALE, Miguel. Lições Preliminares de Direito. Saraiva, São Paulo, 1985.

56. ___ Teoria Tridimensional do Direito. 5a ed., Saraiva, São Paulo, 1994. 
57. SCHIRATO, Vitor Rhein. Discricionariedade e Poder Sancionador: Uma Breve Análise da Proposta de Regulamento da ANATEL. In: Redae, Número 17, Salvador, 2009. Disponível em http://www.direitodoestado.com/revista/REDAE-17FEVEREIRO-2009-VITOR\%20RHEIN.pdf.

58. SUNDFELD, Carlos Ari (Org.). Direito Administrativo Econômico. Malheiros, São Paulo, 2000.

59. TANURE, José Eduardo Pinheiro Santos. Proposta de Procedimentos e Metodologia para Estabelecimento de Metas de Qualidade (DEC e FEC) para Concessionárias de Distribuição de Energia Elétrica Através de Análise Comparativa. Tese de Doutorado, Escola Politécnica da Universidade de São Paulo, São Paulo, 2004.

60. TAVARES, Silvio Romero Ribeiro. O Papel da ANEEL no Setor Elétrico Brasileiro. Dissertação de Mestrado, Faculdade de Engenharia Mecânica da Universidade Estadual de Campinas, Campinas, 2003.

61. VIEIRA, Vanderson Roberto. Infrações e Sanções Administrativas nas Licitações e Contratos Administrativos. In: @ reópago Jurídico, Ano 3, Edição 9, Mirassol, 2010 .

62. VIOLA, Ricardo Rocha. Breve Análise acerca do PND - Programa Nacional de Desestatização. In: Âmbito Jurídico, XIV, n. 94, Rio Grande, 2011. 


\title{
ANEXO A: RESOLUÇÃO NORMATIVA ANEEL n 63/2004
}

\author{
AGÊNCIA NACIONAL DE ENERGIA ELÉTRICA - ANEEL \\ RESOLUÇÃO NORMATIVA Nº 63, DE 12 DE MAIO DE 2004.
}

\begin{abstract}
Aprova procedimentos para regular a imposição de penalidades aos concessionários, permissionários, autorizados e demais agentes de instalações e serviços de energia elétrica, bem como às entidades responsáveis pela operação do sistema, pela comercialização de energia elétrica e pela gestão de recursos provenientes de encargos setoriais.
\end{abstract}

O DIRETOR-GERAL DA AGÊNCIA NACIONAL DE ENERGIA ELÉTRICA - ANEEL, no uso de suas atribuições regimentais, de acordo com deliberação da Diretoria, tendo em vista o disposto no inciso $\mathrm{X}$, art. $3^{\circ}$, da Lei $n^{\circ} 9.427$, de 26 de dezembro de 1996, incluído pelo art. $4^{\circ}$ da Lei ${ }^{\circ}$ 9.648, de 26 de maio de 1998, no art. 24, inciso V, do Anexo da Portaria MME no 349, de 28 de novembro de 1997, nos arts. 16 e 17, Anexo I, do Decreto $\mathrm{n}^{\circ}$ 2.335, de 6 de outubro de 1997, na Lei $\mathrm{n}^{\circ}$ 9.784, de 29 de janeiro de 1999, o que consta do Processo $\mathrm{n}^{\circ} 48500.005062 / 02-10 ; \mathrm{e}$

Considerando que compete à ANEEL, no âmbito de suas atribuições de fiscalização das instalações e serviços de energia elétrica, a apuração de infrações e aplicação de penalidades;

Considerando a necessidade de se adequar, rever e atualizar os procedimentos para apurar infrações e impor penalidades, especialmente em face das alterações na legislação federal aplicável aos processos administrativos em geral;

Considerando a necessidade de se estabelecer procedimento específico para aplicação de penalidades de competência da Diretoria da ANEEL e do Poder Concedente, bem como de se aperfeiçoar o processo punitivo de competência das Superintendências de Fiscalização e das Agências Estaduais Conveniadas;

Considerando a necessidade de compatibilização de procedimentos recursais no âmbito da ANEEL, com a conseqüente adoção de uma única instância junto à autoridade superior (Diretoria), em consonância com a Resolução no 233/98, que disciplina os procedimentos administrativos gerais da Agência;

Considerando a necessidade de se estabelecer critério para atualização do valor das multas aplicadas pela fiscalização, em conformidade com o disposto no $\S 5^{\circ}$, art. 17, do Anexo I ao Decreto $n^{\circ} 2.335 / 97$;

Considerando que dentre as sugestões apresentadas por Agências Estaduais Conveniadas, em atendimento ao Ofício-Circular $n^{\circ} 768 / 2003-D R / A N E E L$, de 4 de dezembro de 2003, diversas propostas contribuíram para o aperfeiçoamento deste ato regulamentar, resolve:

Art. 1o Aprovar procedimentos para regular a imposição de penalidades aos concessionários, permissionários, autorizados e demais agentes de instalações e serviços de energia elétrica, bem como às entidades responsáveis pela operação do sistema, pela comercialização de energia elétrica e pela gestão de recursos provenientes de encargos setoriais. 
Parágrafo único. As penalidades previstas nesta Resolução aplicam-se sem prejuízo das sanções administrativas específicas previstas na legislação e regulamentação setorial vigentes, incluindo normas editadas ou homologadas pela ANEEL, desde que não impliquem mais de uma sanção disciplinar para um mesmo fato gerador.

\section{TÍTULO I \\ DAS PENALIDADES}

Art. 2o As infrações tipificadas nesta resolução sujeitarão a infratora às penalidades de:

I - advertência;

II - multa;

III - embargo de obras;

IV - interdição de instalações;

V - suspensão temporária de participação em licitações para obtenção de novas concessões, permissões ou autorizações, bem como de impedimento de contratar com a ANEEL e de receber autorização para serviços e instalações de energia elétrica;

VI - revogação de autorização;

VII - intervenção administrativa;

VIII - caducidade da concessão ou da permissão.

Parágrafo único. A aplicação das penalidades de que trata este artigo compete:

a) - ao(s) Superintendente(s) responsável(is) pela ação fiscalizadora, nos casos previstos nos incisos I a IV;

b) - à Diretoria, por proposta do(s) Superintendente(s) responsável(is) pela ação fiscalizadora, nos casos referidos nos incisos V a VII.

c) - ao Poder Concedente, por proposta da ANEEL, na hipótese prevista no inciso VIII

\section{Capítulo I \\ DAS INFRAÇÕES E SANÇÕES}

\section{Seção I}

Da Advertência

Art. 3o Constitui infração, sujeita à imposição da penalidade de advertência:

I - deixar de prover as áreas de risco, definidas na legislação, especialmente no Anexo do Decreto no 93.412, de 14.10.86, da instalação de sinalizadores e avisos de advertência de forma adequada à visualização de terceiros;

H- deixar de manter à dispesição des consumidores, em locais acessíveis, nos-escritórios de atendimento å públice:

II - deixar de manter à disposição dos consumidores nos postos de atendimento presencial, em locais acessíveis, os documentos e informações previstos na legislação. (Redação pela REN ANEEL 479 de 03.04.2012.)

a) exemplares da legislação pertinente às condições gerais de fornecimento de energia elétrica;

b) livro para manifestação de reclamações;

c) as normas e padrões do concessionário; e 
d) a tabela com o valor dos serviços cobráveis;

III - deixar de prestar informações aos consumidores, quando solicitado ou conforme determinado pela legislação e regulamentos ou pelo contrato de concessão;

IV - deixar de proceder à organização e atualização de cadastro por unidade consumidora, com informações que permitam a identificação do consumidor, sua localização, valores faturados, histórico de consumo, bem como quaisquer outros dados exigidos por lei ou pelos regulamentos dos serviços delegados;

V - deixar de proceder à organização e atualização de cadastro relativo a cada central geradora, com informações que permitam a identificação do quantitativo da energia gerada, sua localização, seus equipamentos, sua paralisação ou desativação, bem como placa do fabricante em cada unidade geradora, e quaisquer outros dados exigidos por lei ou pelos regulamentos dos serviços;

VI - deixar de proceder à organização e atualização de cadastro relativo a cada instalação de transmissão ou distribuição, com informações que permitam a identificação da sua localização, seus equipamentos, sua modificação, paralisação ou desativação total ou parcial e quaisquer outros dados exigidos por lei ou pelos regulamentos dos serviços;

VII - deixar de atualizar junto à ANEEL o(s) nome(s) do(s) representante(s) legal(is) e o endereço completo, inclusive os respectivos sistemas de comunicação que possibilitem fácil acesso à empresa;

VIII - deixar de encaminhar à ANEEL, nos prazos estabelecidos e segundo instruções específicas, dados estatísticos sobre a produção, comercialização e consumo próprio de energia elétrica;

IX - deixar de manter normas e instruções de operação atualizadas nas instalações e/ou centros de operação de geração, transmissão, transformação e distribuição de energia elétrica;

$\mathrm{X}$ - deixar de registrar ou de analisar as ocorrências nos seus sistemas de transmissão e/ou geração;

XI - deixar de registrar as ocorrências no seu sistema de distribuição;

XII - operar e manter as suas instalações elétricas sem dispor de desenhos, plantas. especificações e/ou manuais de equipamentos devidamente atualizados;

XII classificar incorretamente unidade consumidora, em desacordo com as determinações da legislação; (Revogado pela REN ANEEL 314 de 13.05.2008.)

XIV - deixar de encaminhar o contrato de adesão aos consumidores ou de celebrar contrato de fornecimento, conforme determinado pela legislação;

XV - deixar a Câmara de Comercialização de Energia Elétrica de atender os prazos para envio de informações aos agentes, fixados em regras, procedimentos e/ou em regulamentos da ANEEL.

Seção II

Da Multa

Art. 4o Constitui infração, sujeita à imposição da penalidade de multa do Grupo I:

I - deixar de informar aos consumidores sobre os riscos existentes e os cuidados especiais que a energia elétrica requer;

II - deixar de restituir ao consumidor os valores recebidos, indevidamente, nos prazos estabelecidos na legislação e/ou no contrato;

III - deixar de disponibilizar aos consumidores estrutura de atendimento adequada, que lhes possibilite fácil acesso à empresa;

IV - deixar de atender pedido de serviços nos prazos e condições estabelecidos na legislação e/ou no contrato; 
V - descumprir as determinações da legislação relacionadas ao prévio aviso para a suspensão ou interrupção programada do fornecimento;

VI - deixar de encaminhar à ANEEL, nos prazos estabelecidos e conforme previsto nos regulamentos específicos, indicadores utilizados para a apuração da qualidade do fornecimento de energia elétrica;

VII - deixar de apresentar, nos prazos previstos e segundo as diretrizes da ANEEL, os Programas Anuais de Incremento à Eficiência no Uso e na Oferta de Energia Elétrica, bem como os relativos à Pesquisa e Desenvolvimento Teenológico do Setor Elétrice; (Revogado pela REN ANEEL 300 de 12.02.2008.)

VIII - descumprir as normas de gestão dos reservatórios e das respectivas áreas de proteção;

IX - deixar de implantar ou de manter, nos termos da legislação, as instalações de observações hidrológicas;

X - deixar de enviar à ANEEL, no prazo estabelecido, os dados e as informações necessárias ao cálculo da compensação financeira pela utilização de recursos hídricos;

XI - deixar de organizar e manter atualizado o Calendário de Leitura e Faturamento e/ou deixar de informar aos consumidores, previamente e por escrito, as alterações no referido Calendário;

XII - deixar de enviar à ANEEL, nos prazos estabelecidos em regulamento, contrato ou ato autorizativo, ou quando solicitadas pela fiscalização, informações empresariais relativas à composição acionária da empresa e de seus acionistas, em todos os níveis, e às relações contratuais mantidas entre a empresa, seus acionistas e empresas controladas, coligadas ou vinculadas à controladora;

XIII - deixar de utilizar pessoal técnico, próprio ou de terceiros, legalmente habilitado e devidamente capacitado, para a operação e manutenção das instalações elétricas;

XIV - prestar serviços de atendimento comercial através de pessoal sem a devida capacitação ou treinamento;

XV - deixar de utilizar equipamentos, instalações e métodos operativos que garantam a prestação de serviço adequado;

XVI - deixar de remeter à ANEEL, nos prazos estabelecidos, as informações e os documentos solicitados para a solução de divergências entre agentes ou entre estes e seus consumidores; e,

XVII - deixar de encaminhar à ANEEL, nos prazos e condições estabelecidos, as informações referentes aos contratos de compra e venda de energia elétrica negociados;

XVIII - deixar de prestar informações solicitadas pela ANEEL no prazo estabelecido;

XIX - deixar a Câmara de Comercialização de Energia Elétrica de atender os prazos de envio de informações à ANEEL, previstas em regras, procedimentos ou regulamentos editados ou aprovados pela Agência.

XX - deixar de apresentar, nos prazos previstos e conforme regulamentos estabelecidos pela ANEEL, o Programa de Eficiência Energética e/ou o Programa de Pesquisa e Desenvolvimento Tecnológico do Setor de Energia Elétrica; (Incluído pela REN ANEEL 316 de 13.05.2008.)

Art. 50 Constitui infração, sujeita à imposição da penalidade de multa do Grupo II:

Art. $5^{\circ}$ Constitui infração, sujeita à imposição da penalidade de multa do Grupo II: (Redação dada pela REN ANEEL 278 de 11.09.2007.)

I - deixar de instituir ou de prover condições para o adequado funcionamento do Conselho de Consumidores;

II - descumprir obrigações regulamentares ou contratuais de manter registro atualizado das reclamações e solicitações dos consumidores, com anotação da data e do motivo, bem como de informar ao interessado, no prazo estabelecido, as providências adotadas; 
III - realizar leitura e faturamento em desconformidade com as disposições legais e regulamentares;

IV - deixar de manter registro atualizado dos dados utilizados para apuração dos índices de qualidade do fornecimento de energia elétrica, continuidade e conformidade, segundo definido nos regulamentos específicos, com a anotação, quando for o caso, das causas, dos períodos de duração e das providências adotadas para a solução do problema;

V - deixar de submeter à prévia aprovação da ANEEL, nos casos exigidos pela regulamentação e/ou pelo contrato, projetos de obras e instalações de energia elétrica e suas eventuais modificações, assim como proceder à sua execução em desconformidade com o projeto aprovado e com os prazos estabelecidos;

VI - deixar de efetuar, nos prazos estabelecidos, reparos, melhoramentos, substituições e modificações, de caráter urgente, nas instalações;

VII - deixar de comunicar, imediatamente, aos órgãos competentes, a descoberta de materiais ou objetos estranhos às obras, que possam ser de interesse geológico ou arqueológico;

VIII - descumprir as regras e procedimentos estabelecidos para a implantação ou operação das instalações de geração, transmissão e distribuição de energia elétrica;

IX - deixar de prestar contas da gestão dos serviços concedidos, nos prazos legais e contratuais ou estabelecidos pela ANEEL;

$\mathrm{X}$ - deixar de instalar medidores de energia elétrica e demais equipamentos de medição nas unidades consumidoras, salvo nos casos específicos excepcionados na regulamentação aplicável;

XI - deixar de apurar ou de registrar, separadamente, os investimentos, as receitas e os custos por produção, transmissão, distribuição e comercialização de energia elétrica;

XII - operar centrais geradoras ou instalações da rede básica sem a instalação de medidores de energia elétrica e demais equipamentos de medição exigidos;

XIII - deixar de apresentar o agente as garantias financeiras exigidas para as transações de compra e venda de energia, na forma, condições, limites e prazos previstos em regulamentação específica;

XIV - comercializar energia elétrica fora do âmbito da Câmara de Comercialização sem a contratação de seguro ou fiança bancária nas condições estabelecidas no ato autorizativo;

XV - deixar a Câmara de Comercialização de Energia Elétrica de discriminar, controlar e contabilizar, separadamente, as garantias financeiras oferecidas pelos agentes;

XVI - onerar, sob qualquer forma, as garantias financeiras apresentadas à Câmara de Comercialização de Energia Elétrica;

XVII - causar a Câmara de Comercialização de Energia Elétrica, por sua exclusiva responsabilidade, atraso na execução das etapas do cronograma de contabilização e liquidação financeira das transações efetuadas.

XVII deixar o concessionário, permissionário ou autorizado de atender qualquer obrigação vinculada a declaração de utilidade pública, em seu favor, para fins de desapropriação ou de instituição de servidão administrativa, de áreas de terras necessárias à implantação de instalaçẽes de geração, transmissão- ou distribuição de energia elétrica. (Incluído pela REN ANEEL 278 de 11.09.2007.) (Revogado pela REN ANEEL 560, de 02.07.2013.)

XIX - classificar incorretamente unidade consumidora, em desacordo com as determinações da legislação. (Incluído pela REN ANEEL 314 de 13.05.2008.)

XX - deixar de instituir Ouvidoria ou de prover condições para seu adequado funcionamento; (Incluído pela REN ANEEL 470 de 13.12.2011.)

Art. 6o Constitui infração, sujeita à imposição da penalidade de multa do Grupo III: 
Art. $6^{\circ}$ Constitui infração, sujeita à imposição da penalidade de multa do Grupo III: (Redação dada pela REN ANEEL 285 de 16.10.2007.)

I - descumprir as disposições legais, regulamentares e contratuais relativas aos níveis de qualidade dos serviços e do fornecimento de energia elétrica;

H - deixar de implementar, nos prazos previstos, os Programas Anuais de Incremento à Eficiência no Uso e na Oferta de Energia Elétrica ou os relativos à Pesquisa e Desenvolvimento Tecnológico do Setor Elétrico aprovados pela ANEEL;

II - deixar de investir, conforme regulamentos estabelecidos pela ANEEL, os montantes devidos nos Programas de Eficiência Energética ou os relativos à Pesquisa e Desenvolvimento Tecnológico do Setor de Energia Elétrica; (Redação dada pela REN ANEEL 300 de 12.02.2008.) III - deixar de realizar as obras essenciais à prestação de serviço adequado;

IV - deixar de realizar a contabilização em conformidade com as normas, procedimentos e instruções específicas constantes de regulamento específico aplicável ao setor de energia elétrica;

V - efetuar cessão ou transferência de bens vinculados ao serviço, a qualquer título, bem como dá-los em garantia, em especial conceder aval, fiança, penhor, hipoteca ou qualquer outro comprometimento do patrimônio relacionado à concessão ou permissão, ou a receita dos serviços de energia elétrica, sem prévia e expressa autorização da ANEEL, observado o disposto na legislação;

VI - deixar de registrar, separadamente, os custos referentes aos contratos, acordos ou ajustes celebrados com acionistas controladores, diretos ou indiretos, e empresas controladas ou coligadas; e,

VII - deixar de encaminhar à ANEEL, nos prazos estabelecidos, informações econômicas e financeiras definidas nas disposições legais, regulamentares e contratuais. ;

VIII - deixar de manter segurados, em valores e condições suficientes, suportados por estudos técnicos, os bens e as instalações que, por razões de ordem técnica, sejam essenciais à garantia e confiabilidade do sistema elétrico;

IX - deixar de manter registro, controle e inventário físico dos bens e instalações relacionados à atividade desenvolvida e/ou deixar de zelar pela sua integridade, inclusive aqueles de propriedade da União, em regime especial de uso;

$\mathrm{X}$ - criar dificuldades à fiscalização para o acesso às instalações, bem como a documentos e quaisquer outras fontes de informação pertinentes ao objeto da fiscalização;

XI - descumprir as disposições legais, regulamentares ou contratuais relativas à gestão dos recursos econômicofinanceiros da concessão, permissão ou autorização;

XII - descumprir os prazos estabelecidos nos atos de outorga de concessões, permissões ou autorizações de implantação de instalações de produção, transmissão ou distribuição de energia elétrica;

XIII - deixar de atender ao mercado consumidor, de forma abrangente, nos termos da legislação e do contrato de concessão;

XIV - operar ou manter as instalações de energia elétrica e os respectivos equipamentos de forma inadequada, em face dos requisitos legais, regulamentares e contratuais aplicáveis;

XV - provocar desligamento ou permitir a sua propagação no sistema elétrico em decorrência de falha de planejamento ou de execução da manutenção ou operação de suas instalações;

XVI - deixar de observar os Procedimentos de Rede aprovados pela ANEEL; 
XVII - der causa o agente, por ação ou omissão, ao descumprimento, pela Câmara de Comercialização de Energia Elétrica, das etapas do cronograma de contabilização e liquidação financeira das transações efetuadas;

XVIII - deixar de efetuar o pagamento ou recolhimento, conforme o caso, na data do respectivo vencimento, de qualquer das obrigações e/ou encargos setoriais relativos à compra de energia elétrica mediante contratos regulados ou oriunda de Itaipu Binacional; às quotas da Conta de Consumo de Combustíveis - CCC dos Sistemas Interligados ou Isolados; às parcelas da Conta de Desenvolvimento Energético - CDE; às quotas da Reserva Global de Reversão - RGR; às parcelas dos Juros sobre o Fundo de Reversão aplicado; às parcelas do Uso de Bem Público - UBP; às parcelas da Taxa de Fiscalização dos Serviços de Eletricidade - TFSEE; aos valores da Compensação Financeira pela Utilização de Recursos Hídricos; ao rateio correspondente ao Programa de Incentivo às Fontes Alternativas de Energia Elétrica - PROINFA; às parcelas do Fundo Nacional de Desenvolvimento Científico e Tecnológico - FNDCT; e ao repasse do Encargo de Capacidade Emergencial, assim como de outros encargos que venham a ser estabelecidos por lei.

XIX - deixar de prestar as informações solicitadas pela fiscalização da ANEEL, nos prazos estabelecidos, quanto às ações necessárias ao cumprimento do cronograma aprovado, do qual estão transcritos os marcos principais nos atos de outorga e contratos de concessão para implantação de instalações de geração, transmissão ou distribuição de energia elétrica. (Incluído pela REN ANEEL 285 de 16.10.2007.)

XX - deixar de implementar, nos prazos previstos e conforme regulamentos estabelecidos pela ANEEL, o Programa de Eficiência Energética e/ou o Programa de Pesquisa e Desenvolvimento Tecnológico do Setor de Energia Elétrica. (Incluído pela REN ANEEL 316 de 13.05.2008.)

XXI - deixar de organizar e manter, desde abril de 2002 e até a fiscalização da ANEEL, o cadastro e os históricos de leitura e de faturamento, necessários à comprovação do correto enquadramento de unidades consumidoras na Subclasse Residencial Baixa Renda, aplicando-se a mesma pena quando, após a fiscalização, deixar de manter os dados referentes a abril de 2002; (Incluído pela REN ANEEL 314 de 13.05.2008.)

XXII - solicitar à ANEEL, em desacordo com as disposições legais e regulamentares, a homologação de valores de diferença mensal de receita referente à subvenção econômica concedida à Subclasse Residencial Baixa Renda. (Incluído pela REN ANEEL 314 de 13.05.2008.)

XXIII - descumprir as disposições regulamentares estabelecidas nas Condições Gerais de Fornecimento de Energia Elétrica, não especificadas nos arts. 3, 4\%, $5^{\circ}$ e $7^{\circ}$. (Incluído pela REN ANEEL 479 de 03.04.2012.)

XXIV - descumprir as disposições regulamentares estabelecidas para a prestação de atividades acessórias. (Incluído pela REN ANEEL 581 de 11.10.2013)

Parágrafo único. O disposto nos incisos XIII e XVIII deste artigo não se aplica às hipóteses, respectivamente, de não atendimento das metas acumuladas dos programas anuais, constantes do respectivo plano de universalização de energia elétrica, de que trata a regulamentação específica, e de inadimplemento no recolhimento de encargos e pagamento pela aquisição de energia, a que se refere o art. 10 da Lei no 8.631, de 04.03.93, com a redação dada pela Lei no 10.848 , de 15.03.04.

Art. 7o Constitui infração, sujeita à imposição da penalidade de multa do Grupo IV:

I - estabelecer medidas e procedimentos de racionamento de energia elétrica sem a prévia autorização;

II - praticar valores de tarifas de energia elétrica superiores àqueles autorizados pela ANEEL, observado o disposto no $§ 20$ do art. 15 da Lei no 9.427, de 26 de dezembro de 1996;

III - cobrar dos consumidores serviços não previstos na legislação ou valores desses serviços superiores aos estabelecidos em regulamento;

IV - impor qualquer ônus para o solicitante ou consumidor no atendimento a pedido de ligação ou aumento de carga, no âmbito de Plano de Universalização de Energia Elétrica aprovado pela ANEEL, conforme legislação e regulamentação específicas; 
V - discriminar unidades consumidoras da mesma classificação, atendidas em igual tensão de fornecimento, quanto a cobrança de qualquer natureza ou quando da comercialização de energia elétrica excedente, temporária ou de curto prazo, excetuando-se os consumidores livres;

VI - praticar tarifas de uso e conexão na transmissão e na distribuição não compatíveis com os critérios de acesso e valoração estabelecidos;

VII - deixar de assegurar livre acesso, aos seus sistemas de transmissão e distribuição, a outros agentes do setor de energia elétrica e a consumidores não sujeitos à exclusividade do fornecimento;

VIII - deixar de implementar as medidas objetivando o incremento da eficiência no uso e na oferta de energia elétrica, como estipulado contratualmente;

IX - proceder alteração do estatuto social, transferir ações que implique mudança de seu controle acionário, bem como efetuar reestruturação societária da empresa, sem a anuência prévia da ANEEL;

\section{$\mathrm{X}$ - fornecer informação falsa à ANEEL;}

XI - deixar de registrar, em separado, as atividades não objeto da concessão, ou recusar-se a constituir outra sociedade para o exercício destas atividades, quando exigido;

XII - deixar de submeter ao exame e aprovação da ANEEL, nas hipóteses, condições e segundo procedimentos estabelecidos em regulamentos específicos, os contratos, acordos ou ajustes celebrados com acionistas controladores, diretos ou indiretos, e empresas controladas ou coligadas, em especial os que versem sobre direção, gerência, engenharia, contabilidade, consultoria, empréstimos, venda de ações, transferência de tecnologia, assistência técnica e científica, aquisição de materiais e equipamentos, informática, planejamento, construção, operação, manutenção e supervisão dos sistemas de geração, transmissão e distribuição de energia elétrica, bem como com pessoas físicas ou jurídicas que façam parte, direta ou indiretamente, de uma mesma empresa controlada ou que tenham diretores ou administradores comuns ao agente delegado;

XII - deixar de encaminhar para exame e aprovação da ANEEL, nas hipóteses, condições e segundo procedimentos estabelecidos em regulamento específico, os atos e negócios jurídicos celebrados entre concessionárias, permissionárias e autorizadas e seus controladores, suas sociedades controladas ou coligadas e outras sociedades controladas ou coligadas de controlador comum, bem assim, implementar tais instrumentos contratuais antes da anuência prévia e expressa desta Agência; (Redação dada pela REN ANEEL 334 de 21.10.2008.)

XIII - ultrapassar os limites legais ou regulamentares de participação dos agentes econômicos nas atividades do setor de energia elétrica;

XIV - praticar conduta uniforme ou concertada que vise prejudicar o desenvolvimento normal das operações do mercado de energia elétrica;

XV - explorar atividades de energia elétrica sem concessão, permissão ou autorização;

XVI - deixar de cumprir determinação da Aneel, no prazo estabelecido.

XVII deixar de implantar sistema de monitoramento remoto de grandezas elétricas e consumo de combustível em usina termelétrica localizada em sistema elétrico isolado, beneficiada pela sistemática de rateio da Conta de Consumo de Combustíveis Fósseis CCC. (Incluído pela REN ANEEL 163 de 01.08.2005.)

XVII - deixar de implantar e operar adequadamente o Sistema de Coleta de Dados Operacionais (SCD) em empreendimento beneficiado pela sistemática de rateio da Conta de Consumo de Combustíveis Fósseis - CCC. (Redação dada pela REN ANEEL 427 de 22.02.2011.)

XVIII - ultrapassar o padrão de frequiência de outros desligamentos, conforme metodologia do art. 32 e tabela do item 1 do Anexo da Resolução nº 270/2007; (Incluído pela REN ANEEL 270 de 26.06.2007.)

XIX - deixar de prestar serviços públicos de transmissão, conforme art. 33 da Resolução nº 270/2007. (Incluído pela REN ANEEL 270 de 26.06.2007.) 
XX - descumprir o agente da CCEE obrigação estabelecida na Convenção de Comercialização de Energia Elétrica instituída pela ANEEL. (Incluído pela REN ANEEL 274 de 07.08.2007.)

XXI - implementar contratos que não observem os critérios gerais e específicos definidos em regulamento específico da ANEEL para a celebração de atos e negócios jurídicos entre concessionárias, permissionárias e autorizadas do setor de energia elétrica e seus controladores, suas sociedades controladas ou coligadas e outras sociedades controladas ou coligadas de controlador comum. (Incluído pela REN ANEEL 334 de 21.10.2008.)

XXII - celebrar e implementar contrato distinto da versão examinada e aprovada pela ANEEL. (Incluído pela REN ANEEL 334 de 21.10.2008.)

XXII Solicitar reembelso de combustível oriundo da Conta de Consumo de Combustíveis Fósseis CCC, em valores e/ou quantidades superiores aos limites praticados ou estabelecidos pela ANEEL. (Incluído pela REN ANEEL 350 de 21.01.2009.)

XXIII - Solicitar reembolso oriundo da Conta de Consumo de Combustíveis Fósseis - CCC em valores e/ou quantidades superiores aos reconhecidos pela ANEEL. (Redação dada pela REN ANEEL 427 de 22.02.2011.)

XXIV deixar a Câmara de Comercialização de Energia Elétrica de observar a Convenção, as Regras ou os Procedimentos de Comercialização, incluindo a Convenção Arbitral, ou ainda o Estatto da CCEE, aprovados ou homologados pela ANEEL, em questões não disciplinadas em hipóteses específicas constantes desta Resolução. (Incluído pela REN ANEEL 393 de 14.12.2009.)

XXIV - deixar a Câmara de Comercialização de Energia Elétrica - CCEE de observar a Convenção, as Regras ou os Procedimentos de Comercialização, incluindo a Convenção Arbitral, o disposto em regulamento atinente ao desligamento de agentes ou impugnação de seus atos, ou ainda o Estatuto da CCEE, aprovados ou homologados pela ANEEL, em questões não disciplinadas em hipóteses específicas constantes desta Resolução. (Redação pela REN ANEEL 545 de 16.04.2013)

XXV - deixar de implantar e operar adequadamente o Sistema de Coleta de Dados Operacionais para a CDE (SCDCDE) em empreendimento beneficiado pela Conta de Desenvolvimento Energético - CDE. (Incluído pela REN ANEEL 500 de 17.07.2012.)

XXVI - Solicitar reembolso oriundo da Conta de Desenvolvimento Energético - CDE em valores e/ou quantidades superiores aos reconhecidos pela ANEEL. (Incluído pela REN ANEEL 500 de 17.07.2012.)

Art. $8^{\circ}$ A penalidade de multa capitulada nos arts. $4^{\circ}, 5^{\circ}, 6^{\circ}$ e $7^{\circ}$ desta Resolução poderá ser convertida em advertência, desde que:

I - a infratora não tenha sido autuada por idêntica infração nos últimos quatro anos anteriores ao da sua ocorrência; e

II - as conseqüências da infração sejam de pequeno potencial ofensivo.

$$
\text { Seção III }
$$

Do Embargo de Obras e da Interdição de Instalações

Art. $9^{\circ}$ Sem prejuízo das penalidades de advertência e multa, constitui infração, sujeita às penalidades de embargo ou interdição, respectivamente, a realização de obras ou a posse de instalações, sem a necessária autorização ou concessão da ANEEL ou que ponham em risco a integridade física ou patrimonial de terceiros.

Parágrafo único. Na hipótese da aplicação das penalidades de embargo de obras ou de interdição de instalações, o recurso será recebido sem o efeito suspensivo.

\section{Seção IV}

Da Suspensão do Direito de Participar de Licitações e de Contratar com a ANEEL 
Art.10. Constitui infração, sujeita à penalidade prevista no inciso $\mathrm{V}$ do art. $2^{\circ}$ desta Resolução, a inexecução total ou parcial de obrigações legais, regulamentares e contratuais, de que possa resultar grave prejuízo às atividades do setor de energia elétrica ou que representem, nos termos do § 3o do art. 17 do Anexo do Decreto no

2.335/97, reiterada violação ou descumprimento de:

I - padrões de qualidade de serviços;

II - prazo para entrada de operações de instalações;

III - determinações da ANEEL;

IV - obrigações relacionadas às transações de compra e venda de energia elétrica no âmbito da Câmara de Comercialização.

§ 1o A suspensão temporária de participação em licitações para obtenção de novas concessões, permissões ou autorizações, bem como o impedimento de contratar com a ANEEL e de receber autorização para serviços e instalações de energia elétrica alcançam também o acionista controlador da infratora.

§ 2o O prazo de suspensão e/ou de impedimento, a que se refere o parágrafo anterior, não será superior a dois anos.

\section{Seção V}

Da Revogação de Autorização

Art. 11. Constituem infrações, sujeitas à penalidade de revogação de autorização, aquelas previstas na legislação e nos atos autorizativos que, a critério da ANEEL, impliquem prejuízo considerável ao desenvolvimento das atividades autorizadas e/ou configurem sistemática inadimplência do seu titular, especialmente nas hipóteses de:

I - descumprimento de cronogramas, obrigações e encargos decorrentes da autorização;

II - transferência a terceiros dos bens e instalações sem prévia e expressa autorização da ANEEL, quando aplicável;

III - não recolhimento de multa decorrente de penalidade imposta à autorizatária;

IV - descumprimento de notificação da fiscalização para regularizar a exploração do empreendimento objeto da autorização, quando for o caso;

V - comercialização da energia elétrica em desacordo com as prescrições da legislação, das normas específicas e do ato autorizativo;

VI - permanência por mais de vinte e quatro meses contínuos sem atuação no mercado ou, por igual período, inexistência de contrato de compra e venda de energia elétrica.

VII - desligamento do agente da Câmara de Comercialização de Energia Elétrica - CCEE, por inadimplemento. (Incluído pela REN ANEEL 545 de 16.04.2013)

\section{Seção VI}

Da Intervenção Administrativa

Art. 12. A concessão e a permissão de serviços e instalações de energia elétrica estarão sujeitas à intervenção administrativa nos termos da legislação, em especial da Lei nº 8.987, de 1995, a qual poderá ser decretada em caso de:

I - inadequação dos serviços prestados ou da exploração de instalações concedidas ou permitidas, não resolvida no prazo determinado;

II - desequilíbrio econômico-financeiro decorrente de gestão que coloque em risco a continuidade dos serviços; 
III - verificação de reiteradas infrações a normas contratuais, regulamentares e legais pertinentes, não regularizadas após determinação da ANEEL;

IV - descumprimento injustificado de metas de universalização;

$\mathrm{V}$ - recusa injustificada de interconexão;

VI - infração da ordem econômica, nos termos da legislação própria;

VII - prática de ato que coloque em risco a prestação do serviço concedido ou permitido;

VIII - pedido de concordata.

§ 1o A intervenção será determinada por Resolução da ANEEL, que indicará seu prazo, objetivo e limites da medida, em função das razões que a ensejaram, e designará o interventor.

§ 2o A decretação da intervenção não afetará o curso regular dos negócios da concessionária ou permissionária, nem seu normal funcionamento e produzirá, de imediato, o afastamento dos respectivos administradores.

§ 3o A assembléia de acionistas da concessionária ou permissionária subsiste durante a intervenção sem, todavia, intervir na gestão dos negócios.

§ 4o A intervenção poderá ser prorrogada se persistirem os motivos de sua decretação.

§ 5o Declarada a intervenção, a ANEEL instaurará, no prazo de trinta dias, procedimento administrativo para comprovar as causas determinantes da medida e apurar responsabilidades, assegurado o direito de ampla defesa, devendo o mesmo ser concluído no prazo de até cento e oitenta dias, sob pena de considerar-se inválida a intervenção.

$\S 60$ Dos atos do interventor caberá recurso à Diretoria da ANEEL.

§ 7o Para os atos de alienação e disposição do patrimônio da concessionária ou permissionária, o interventor necessitará de prévia autorização da Diretoria da ANEEL.

§ 80 O interventor prestará contas e responderá pelos atos praticados durante a sua gestão.

\section{Seção VII}

Da Caducidade da Concessão ou da Permissão

Art. 13. A concessão e a permissão de serviços de energia elétrica estarão sujeitas à declaração de caducidade, nos termos da legislação, em especial da Lei $n^{\circ}$ 8.987, de 1995, bem assim do respectivo contrato de concessão ou permissão, quando:

I - o serviço estiver sendo prestado de forma inadequada ou deficiente, tendo por base, as normas, critérios, indicadores e parâmetros definidores da qualidade do serviço;

II - a concessionária ou permissionária descumprir cláusulas contratuais ou disposições legais ou regulamentares concernentes à concessão ou permissão;

III - a concessionária ou permissionária paralisar o serviço ou concorrer para tanto, ressalvadas as hipóteses decorrentes de caso fortuito ou força maior;

IV - a concessionária ou permissionária perder as condições econômicas, técnicas ou operacionais para manter a adequada prestação do serviço concedido ou permitido;

V - a concessionária ou permissionária não cumprir as penalidades impostas por infrações, nos devidos prazos;

VI - a concessionária ou permissionária não atender a intimação da ANEEL no sentido de regularizar a prestação do serviço; 
VII - a concessionária ou permissionária for condenada em sentença transitada em julgado por sonegação de tributos, inclusive contribuições sociais.

VIII - houver desligamento do agente da Câmara de Comercialização de Energia Elétrica - CCEE, por inadimplemento. (Incluído pela REN ANEEL 545 de 16.04.2013)

§ 1o A declaração de caducidade da concessão ou permissão deverá ser precedida da verificação da inadimplência da concessionária ou permissionária em processo administrativo, assegurado o direito de ampla defesa.

§ 2o Não será instaurado processo administrativo de inadimplência antes de comunicados à concessionária ou permissionária, detalhadamente, os descumprimentos contratuais referidos nos incisos deste artigo, dando-lhe um prazo para corrigir as falhas e transgressões apontadas e para o enquadramento, nos termos contratuais.

§ 3o Instaurado o processo administrativo e comprovada a inadimplência, a caducidade será declarada pelo Poder Concedente, por proposta da ANEEL, independentemente de indenização prévia, a qual será calculada no decurso do processo.

§ 4o A indenização de que trata o parágrafo anterior será apurada com base nas parcelas dos investimentos vinculados aos bens reversíveis, ainda não amortizados ou depreciados, que tenham sido realizados com o objetivo de garantir a continuidade e atualidade do serviço concedido ou permitido, descontados o valor das multas contratuais e dos danos causados pela concessionária ou permissionária.

§ 5o O valor de indenização dos bens reversíveis será aquele resultante de inventário procedido pela ANEEL ou por preposto especialmente designado, e seu pagamento realizado com os recursos da Reserva Global de Reversão - RGR, na forma da legislação específica, após finalizado o processo administrativo e esgotados todos os prazos e instâncias recursais.

§ 6o Declarada a caducidade, não resultará para o poder concedente ou para a ANEEL qualquer espécie de responsabilidade em relação aos encargos, ônus, obrigações ou compromissos com terceiros ou com empregados da concessionária ou permissionária.

\section{Capítulo II \\ DOS CRITÉRIOS PARA FIXAÇÃO DAS MULTAS}

Art. 14. Sem prejuízo do disposto em regulamento específico ou contrato de concessão, os valores das multas serão determinados mediante aplicação, sobre o valor do faturamento, nos casos de concessionários, permissionários e autorizados de instalações e serviços de energia elétrica, ou sobre o valor estimado da energia produzida, nos casos de auto-produção e produção independente, correspondente aos últimos doze meses anteriores à lavratura do Auto de Infração, dos seguintes percentuais:

Grupo I: até $0,01 \%$ (um centésimo por cento);

Grupo II: até $0,10 \%$ (dez centésimos por cento);

Grupo III: até $1 \%$ (um por cento);

Grupo IV: até $2 \%$ (dois por cento).

$\S$ 1o Para fins do que trata este artigo, entende-se por valor do faturamento as receitas oriundas da venda de energia elétrica e prestação de serviços, deduzidos o ICMS e o ISS.

§ 2o Para a determinação do valor estimado da energia produzida será utilizada a seguinte fórmula:

$\mathrm{VEEP}=\mathrm{CP} \times \mathrm{FC} \times \mathrm{PME}$

Onde:

VEEP = Valor Estimado da Energia Produzida; 
$\mathrm{CP}=$ Capacidade Instalada da central geradora $(\mathrm{em} \mathrm{kW})$;

FC = Fator de Capacidade da central geradora, constante do respectivo ato autorizativo ou da sua ficha técnica na ANEEL ou, quando não indicado nestes, 0,55 para hidrelétricas, 0,30 para eólicas e 0,80 para os demais tipos de fontes;

PME = Preço Médio da Energia (em R $\$ / k W h)$ no submercado onde se situe a unidade de geração da infratora, correspondente aos últimos doze meses anteriores ao da lavratura do auto de infração.

§ 3o No caso do tempo de operação ou de funcionamento das instalações da empresa punida ser inferior a doze meses, a base de cálculo será a receita ou o faturamento anual estimado pela ANEEL.

$\S 4$ o Tratando-se das entidades responsáveis pela operação do sistema, pela câmara de comercialização de energia elétrica e pela gestão dos recursos provenientes de encargos setoriais, as multas serão determinadas mediante a aplicação dos percentuais referidos no "caput" deste artigo sobre:

I os valores das receitas antais auferidas pela entidade encarregada da operação do sistema e pela câmara de energia elétrica, conforme ocaso;

I o valor arrecadado pela entidade gestora, nos últimos doze meses, relativamente ao fundo setorial cerrespendente.

I - o montante do último orçamento anual aprovado pela ANEEL, ficando vedado o repasse tarifário da respectiva penalidade; (Redação dada pela REN ANEEL 393 de 14.12.2009.)

II - os valores das receitas anuais decorrentes das contribuições associativas dos agentes, no caso da Câmara de Comercialização de Energia Elétrica - CCEE; (Redação dada pela REN ANEEL 393 de 14.12.2009.)

III - o valor arrecadado pela entidade gestora, nos últimos doze meses, relativamente ao fundo setorial correspondente. (Incluído pela REN ANEEL 393 de 14.12.2009.)

§ 5o Para infração relacionada a transações de compra e venda de energia, cometida por consumidor livre, a multa será calculada aplicando-se o percentual do grupo correspondente sobre o somatório do valor das faturas de energia da unidade consumidora, nos últimos doze meses.

Art. 15. Na fixação do valor das multas serão consideradas a abrangência e a gravidade da infração, os danos dela resultantes para o serviço e para os usuários, a vantagem auferida pela infratora e a existência de sanção administrativa irrecorrível, nos últimos quatro anos.

Art. 16. Ocorrendo a reincidência, proceder-se-á da seguinte forma:

I - aplicar multa correspondente ao Grupo I, para os casos anteriormente puníveis com advertência;

II - aplicar acréscimo de cinqüenta por cento sobre o valor da multa, limitado o montante ao percentual de dois por cento, de que trata o art. 14 desta Resolução.

$\S 1$ 1o Entende-se por reincidência, para os fins de agravamento de penalidade de que trata este artigo, a repetição de falta de igual natureza no período de doze meses após a decisão irrecorrível na esfera administrativa.

$\S 20$ No que se refere especificamente a indicadores de qualidade do serviço, configura falta de igual natureza a ocorrência de violação a padrões de qualidade dentro de um mesmo conjunto de unidades consumidoras.

Art. 17. Na hipótese da ocorrência concomitante de mais de uma infração, serão aplicadas, simultânea e cumulativamente, as penalidades correspondentes a cada uma delas.

TÍTULO II

DOS PROCEDIMENTOS

Capítulo I

DA AÇÃO FISCALIZADORA 
Art. 18. A ação fiscalizadora será consubstanciada em relatório de fiscalização, do qual se fará Termo de Notificação (TN), emitido em duas vias, contendo:

I - identificação do órgão fiscalizador e respectivo endereço;

II - nome, endereço e qualificação da notificada;

III - descrição dos fatos levantados;

IV - indicação de não conformidade(s) e/ou determinação de ações a serem empreendidas pela notificada, se for o caso;

V - identificação do representante do órgão fiscalizador, com seu cargo, função, número da matrícula e assinatura;

VI - local e data da lavratura.

Parágrafo único. Uma via do TN será entregue, ou enviada mediante registro postal com Aviso de Recebimento (AR), ao representante legal da notificada ou ao seu procurador habilitado, para conhecimento e manifestação, se for o caso, sempre acompanhada, se existir, do respectivo relatório de fiscalização.

Art. 19. A notificada terá o prazo de quinze dias, contado do recebimento do TN, para manifestar-se sobre o objeto do mesmo, inclusive juntando os elementos de informação que julgar convenientes.

$\S$ 1o Decorrido este prazo, uma cópia do TN, acompanhada do relatório de fiscalização e de eventual manifestação da notificada, será encaminhada para análise da(s) Superintendência(s) envolvida(s) com os fatos levantados.

§ 2o Quando da análise da manifestação da notificada, poderão ser solicitadas outras informações julgadas necessárias ao melhor esclarecimento dos fatos relatados.

§ 3o A Superintendência responsável pela ação fiscalizadora poderá, excepcionalmente, conceder prorrogação do prazo, desde que solicitada tempestivamente e devidamente justificada pela notificada.

Art. 20. A decisão acerca da instauração do processo administrativo formado com base nos arts. 18 e 19 , relativamente aos fatos que possam resultar na imposição das penalidades de que tratam os incisos I a IV do art. 2o desta Resolução, será proferida pelo Superintendente responsável pela ação fiscalizadora e comunicada à notificada no prazo de quarenta e cinco dias, contado do recebimento da respectiva manifestação ou da fruição do prazo de que trata o artigo anterior.

$\S 1$ lo O TN será arquivado quando não comprovada a não conformidade ou sendo consideradas procedentes as alegações da notificada.

§ 2o Será lavrado Auto de Infração, com observância do procedimento estabelecido no Capítulo III, Título II, desta Resolução, nos casos de:

I - comprovação da não conformidade;

II - ausência de manifestação tempestiva da interessada;

III - serem consideradas insatisfatórias as alegações apresentadas;

IV - não serem atendidas, no prazo, as determinações da ANEEL.

Capítulo II

DO TERMO DE COMPROMISSO DE AJUSTE DE CONDUTA

Art. 21. Poderá a ANEEL, alternativamente à imposição de penalidade, firmar com a concessionária, permissionária ou autorizala termo-de compromisso de ajuste de conduta, visando à adequação-da-conduta 
irregular às dispesiçẽes regulamentares e/ou contratuais aplicáveis.

Art. 21. Poderá a ANEEL, alternativamente à imposição de penalidade, firmar com a concessionária, permissionária ou autorizada de serviços e instalações de energia elétrica termo de compromisso de ajuste de conduta, visando à adequação da conduta irregular às disposições regulamentares e/ou contratuais aplicáveis, conforme regulamentação específica. (Redação dada pela REN ANEEL 333 de 07.10.2008.)

$\S 1^{\circ} \mathrm{O}$ termo de compromisso de ajuste de conduta será submetido à aprovação da Diretoria da ANEEL pela Superintendência onde o processo se originar.

$\S 2^{\circ}$ As metas e compromissos objeto do termo referido neste artigo deverão, no seu conjunto, ser compatíveis com as obrigações previstas nos regulamentos e contratos regedores da prestação de serviços de energia elétrica descumpridas pela concessionária, permissionária ou autorizada.

$\S 3^{\circ}$ Do termo de compromisso de ajuste de conduta constará, necessariamente, o estabelecimento de multa pelo seu descumprimento, cujo valor será correspondente ao montante da penalidade que seria aplicada, acrescido de $20 \%$ (vinte por cento).

\section{Capítulo III \\ DO PROCEDIMENTO PARA APLICAÇÃ̂̃O DE PENALIDADES DE COMPETÊNCIA DAS SUPERINTENDÊNCIAS DE FISCALIZAÇÃO}

Art. 22. O Auto de Infração (AI), emitido pelo Superintendente responsável pela ação fiscalizadora, será instruído com o TN, salvo na hipótese do art. $9^{\circ}$, e a respectiva manifestação da notificada, se houver, bem assim com a exposição de motivos da autuação e outros documentos a esta relacionados, que não implique duplicidade da documentação constante do processo de fiscalização correspondente.

Parágrafo único. O AI, quando eivado de vício ou incorreção, poderá ser retificado de ofício pelo Superintendente responsável. Neste caso, abrir-se-á novo prazo à autuada para apresentação de recurso.

Art. 23. O Auto de Infração será emitido em duas vias, contendo:

I - o local e a data da lavratura;

II - o nome, o endereço e a qualificação da autuada;

III - a descrição do(s) fato(s) ou do(s) ato(s) constitutivo(s) da(s) infração(ões); IV - a indicação dos dispositivos legais, regulamentares, ou contratuais infringidos e as respectivas penalidades;

V - a indicação do prazo de dez dias para recolhimento da multa, se for o caso, ou apresentação de recurso;

VI - as instruções para o recolhimento da multa; e,

VII - a identificação do Superintendente autuante, a quem poderá ser interposto o recurso, sua assinatura, a indicação do seu cargo ou função e o número de sua matrícula.

Parágrafo único. Uma via do AI será remetida, ou entregue, para efeito de notificação, ao representante legal da autuada, ou ao seu procurador habilitado, mediante registro postal com Aviso de Recebimento (AR) ou outro documento que comprove o respectivo recebimento.

Art. 24. O valor da multa será atualizado pela taxa SELIC ou outro indicador que o venha substituir, conforme previsto no $\S 5^{\circ}$ do art. 17 do Anexo I do Decreto no 2.335, de 6 de outubro de 1997, e observado o disposto no parágrafo único deste artigo.

Parágrafo único. Será considerada a variação acumulada pro rata die da taxa SELIC no período compreendido entre o segundo dia anterior ao término do prazo estabelecido no AI e o segundo dia anterior à data do efetivo pagamento da multa. 
Art. 25. Havendo o recolhimento da multa e observado, quando couber, o disposto no artigo antecedente, a autuada deverá encaminhar à ANEEL e à agência estadual conveniada, conforme o caso, uma via do respectivo comprovante, devidamente autenticado e sem rasuras.

Art. 26. O não recolhimento da multa no prazo estipulado no AI, sem interposição de recurso, ou no prazo estabelecido em decisão irrecorrível na esfera alministrativa, acarretará $\theta$ imediato encaminhamento do process $\Theta$ administrativo à Procuradoria Federal junto a ANEEL, para a inscrição do valor correspondente na Dívida Ativa da União e respectiva cobrança, nos termos da Lei no 6.830, de 22 de setembro de 1980, bem como a inscrição do devedor no Cadastro Informativo dos Créditos Não Quitados de Órgãos e Entidades Federais (CADIN).

Art. 26. O não recolhimento da multa no prazo estipulado no AI, sem interposição de recurso, ou no prazo estabelecido em decisão irrecorrível na esfera administrativa, acarretará imediato encaminhamento do processo administrativo à Superintendência de Administração e Finanças - SAF da ANEEL, para inscrição do devedor no Cadastro Informativo dos Créditos Não Quitados de Órgãos e Entidades Federais - CADIN, nos termos da Lei $\mathrm{n}^{\circ}$ 10.522, de 19 de julho de 2002, e posterior encaminhamento à Procuradoria Federal para inscrição do valor correspondente na Dívida Ativa e respectiva execução, nos termos da Lei nº 6.830, de 22 de setembro de 1980. (Redação dada pela REN ANEEL 317 de 13.05.2008.)

\section{Capítulo IV \\ DO PROCEDIMENTO PARA APLICAÇÃO DE PENALIDADES DE COMPETÊNCIA DA DIRETORIA DA ANEEL OU DO PODER CONCEDENTE}

Art. 27. Com base em ação específica de fiscalização e/ou em relatório(s) de acompanhamento de fiscalização(ões) - (RAF) anteriormente realizada(s), o(s) Superintendente(s) responsável(is), constatando a existência de fatos que possam, de per si ou conjuntamente, caracterizar qualquer das infrações a que aludem os incisos V, VI, VII e VIII do art. $2^{\circ}$ desta Resolução, proporá(ão) à Diretoria da ANEEL que seja cientificado o agente acerca dessa circunstância, mediante Termo de Intimação - TI, o qual se fará acompanhar de exposição circunstanciada de motivos e, na hipótese de caducidade de concessão ou permissão, de relatório de comunicação de falhas e transgressões à legislação e ao contrato de concessão ou permissão, com a fixação de prazo para a sua regularização definitiva.

Art. 28. Entendendo cabível a iniciação do procedimento proposto, a Diretoria autorizará, mediante Despacho, a expedição, por parte do(s) Superintendente(s) responsável(is) pela ação fiscalizatória, do Termo de Intimação TI a que se refere o artigo antecedente, o qual será lavrado em três vias e deverá conter, necessariamente:

I - identificação do(s) órgão(s) fiscalizador(es);

II - nome, endereço e qualificação da intimada;

III - descrição resumida dos fatos levantados;

IV - indicação de não conformidade(s) e/ou determinação de ações a serem empreendidas pela intimada, se for o caso, com seus respectivos prazos;

V - especificação do ato da Diretoria que autoriza a emissão do TI correspondente;

VI - informação de que a contestação da intimada deverá ser dirigida à Diretoria da ANEEL;

VII - nome(s) e assinatura(s) do(s) Superintendente(s) responsável(is);

VIII - local e data da lavratura.

$\S 1^{\circ}$ Uma via do TI será entregue, ou enviada mediante registro postal com Aviso de Recebimento (AR), ao representante legal da intimada ou ao seu procurador habilitado, para conhecimento e providências pertinentes.

$\S 2^{\circ}$ A segunda via do TI será encaminhada à Secretaria-Geral da ANEEL, para acompanhamento e controle, enquanto a terceira será autuada no respectivo processo. 
Art. 29. Aplicam-se ao Termo de Intimação as disposições constantes do art. 19 e respectivos parágrafos desta Resolução, substituindo-se a instância do Superintendente pela da Diretoria.

Art. 30. A decisão acerca da aplicação das penalidades de que tratam os incisos V e VI do art. $2^{\circ}$ desta Resolução será proferida pela Diretoria da ANEEL e comunicado o seu inteiro teor à infratora, no prazo de sessenta dias, contados do recebimento da respectiva manifestação ou da fruição do prazo referido no art. 19 anterior.

$\S 1^{\circ}$ A decisão referida no "caput" deste artigo consubstanciar-se-á em Resolução da ANEEL, a ser publicada no Diário Oficial da União, sem prejuízo do envio à infratora, mediante registro postal com aviso de recebimento, do inteiro teor de sua fundamentação, incluindo votos, pareceres e demais subsídios utilizados no processo decisório.

$\S 2^{\circ}$ Será imposta a correspondente penalidade ao agente infrator nos seguintes casos:

a) - confirmação da(s) não conformidade(s);

b) - ausência de manifestação tempestiva da intimada;

c) - serem consideradas insatisfatórias as alegações apresentadas; ou

d) - não serem atendidas, no prazo, as determinações da ANEEL.

Art. 31. Cabe pedido de reconsideração da decisão de que trata o artigo antecedente, distribuindo-se os autos a novo relator.

Parágrafo único. Aplicam-se ao pedido de reconsideração, no que couber, as regras sobre o recurso.

Art. 32. Tratando-se de fato(s) a que corresponda a aplicação da penalidade de caducidade da concessão ou da permissão, a ANEEL encaminhará os autos do respectivo processo administrativo, devidamente instruído, ao(à) Ministro(a) de Estado de Minas e Energia, com vistas à decisão do Poder Concedente.

Parágrafo único. Do referido processo constará Relatório circunstanciado, indicando as falhas e transgressões à legislação e ao contrato de concessão ou permissão, não regularizadas nos prazos determinados no TI encaminhado pela fiscalização, nos termos dos arts. 27 a 29 antecedentes.

\section{Capítulo V \\ Do Recurso}

Art. 33. O prazo para interposição de recurso será de dez dias, contado do recebimento do AI.

Parágrafo único. O recurso terá efeito suspensivo na parte em que impugnar o AI, observada a excepcionalidade contida no parágrafo único do art. $9^{\circ}$ desta Resolução.

Art. 34. O recurso será dirigido à autoridade que proferiu a decisão, a qual, se não a reconsiderar, no prazo de cinco dias, o encaminhará à Diretoria da ANEEL, que poderá confirmar, modificar, anular ou revogar, total ou parcialmente a decisão recorrida.

$\S 1^{\circ}$ Se da aplicação do disposto no "caput" deste artigo puder decorrer gravame à situação da recorrente, esta deverá ser cientificada para que formule suas alegações no prazo de dez dias, contado da juntada do aviso de recebimento da notificação.

$\S 2^{\circ} \mathrm{Na}$ tramitação do recurso serão observados os procedimentos estabelecidos na Norma de Organização ANEEL - 001, aprovada pela Resolução nº 233, de 14 de julho de 1998.

$\S 3^{\circ}$ No caso de aplicação da penalidade de multa, a recorrente terá o prazo de dez dias para efetuar o respectivo recolhimento, contado da data de publicação da decisão da Diretoria acerca do recurso.

Art. 35. A critério da Diretoria da ANEEL, poderá ser realizada Audiência Pública no intuito de ouvir as partes interessadas no processo administrativo punitivo, determinando, se necessário, novas diligências processuais e novos prazos. 


\author{
Capítulo VI \\ Do Parcelamento de Multa \\ (Incluído pela REN ANEEL 317 de 13.05.2008.)
}

Art. 35-A. Os débitos originários de multas aplicadas pela ANEEL ou Agências Conveniadas poderão ser pagos em até doze parcelas mensais e sucessivas, mediante requerimento dirigido ao Superintendente de Administração e Finanças da ANEEL, não podendo cada parcela ser inferior a R \$ 10.000,00 (dez mil reais). (Incluído pela REN ANEEL 317 de 13.05.2008.)

$\S 1^{\circ} \mathrm{O}$ requerimento deverá ser assinado pelo representante legal do agente autuado ou preposto legalmente habilitado, com reconhecimento em cartório. (Incluído pela REN ANEEL 317 de 13.05.2008.)

$\S 2^{\circ} \mathrm{O}$ requerimento deverá ser protocolado junto à ANEEL dentro do prazo fixado para o recolhimento da multa. (Incluído pela REN ANEEL 317 de 13.05.2008.)

$\S 3^{\circ} \mathrm{O}$ pedido de parcelamento constitui confissão irretratável e extrajudicial do débito. (Incluído pela REN ANEEL 317 de 13.05.2008.)

$\S 4^{\circ}$ Ao formular o pedido de parcelamento, o requerente deverá comprovar o pagamento de valor correspondente à primeira parcela, conforme o montante do débito e o prazo solicitado. (Incluído pela REN ANEEL 317 de 13.05.2008.)

$\S 5^{\circ}$ O Superintendente de Administração e Finanças da ANEEL deliberará sobre o requerimento em até 10 (dez) dias após o recebimento do pedido de parcelamento. (Incluído pela REN ANEEL 317 de 13.05.2008.)

$\S 6^{\circ} \mathrm{O}$ pedido de parcelamento deverá ser feito utilizando-se formulário próprio da ANEEL, configurando motivo para indeferimento do pedido o não preenchimento de todos os campos destinados ao solicitante. (Incluído pela REN ANEEL 317 de 13.05.2008.)

$\S 7^{\circ}$ A concessão de parcelamento ao agente fica condicionada à adimplência para com as obrigações intrasetoriais. (Incluído pela REN ANEEL 317 de 13.05.2008.)

Art. 35-B. As parcelas serão remuneradas em conformidade com o disposto no art. 24 desta Resolução. (Incluído pela REN ANEEL 317 de 13.05.2008.)

Parágrafo único. Após pagamento da primeira parcela, as parcelas restantes terão vencimento no mês subseqüente ao deferimento do pedido, sempre no dia 10 (dez) de cada mês. (Incluído pela REN ANEEL 317 de 13.05.2008.)

Art. 35-C. O parcelamento será cancelado automaticamente quando houver atraso superior a 30 (trinta dias) de qualquer parcela. (Incluído pela REN ANEEL 317 de 13.05.2008.)

Art. 35-D. Um novo pedido de parcelamento de multa somente poderá ser deferido depois de quitado parcelamento anteriormente concedido. (Incluído pela REN ANEEL 317 de 13.05.2008.)

Art. 35-E. A ANEEL publicará, mensalmente, demonstrativo dos parcelamentos deferidos, nos termos do art. 12 , $\S 4^{\circ}$, da Lei $n^{\circ} 10.522$, de 2002. (Incluído pela REN ANEEL 317 de 13.05.2008.)

Art. 35-F. A concessão do parcelamento e o respectivo pagamento das parcelas implicam suspensão da inscrição do solicitante no CADIN, previsto na Lei $\mathrm{n}^{\circ} 10.522$, de 2002, relativo ao débito parcelado. (Incluído pela REN ANEEL 317 de 13.05.2008.)

Art. 35-G. A quitação do parcelamento implica baixa da inscrição do solicitante no CADIN, previsto na Lei $\mathrm{n}^{\circ}$ 10.522, de 2002, em relação ao débito parcelado. (Incluído pela REN ANEEL 317 de 13.05.2008.)

\author{
TÍTULO III \\ DAS DISPOSIÇÕES FINAIS
}


Art. 36. Em qualquer momento do processo administrativo punitivo, incluindo a fase recursal, poderá ser instada a Procuradoria Federal junto a ANEEL para emitir parecer, no prazo de quinze dias.

Art. 37. As agências conveniadas com a ANEEL, para a execução das atividades descentralizadas, poderão aplicar as penalidades referidas nos incisos I, II, III e IV, bem como propor à Diretoria da ANEEL a imposição daquelas indicadas nos incisos V, VI, VII e VIII, do art. $2^{\circ}$, e a celebração de termos de compromisso de ajuste de conduta, previstos no art. 21, desta Resolução.

§ 1o Quando da execução da ação fiscalizadora pelas agências conveniadas, serão aplicados os procedimentos de que tratam os Capítulos I, II, III e IV, do Título II, desta Resolução.

$\S 20$ Os procedimentos referidos no parágrafo anterior poderão ser ajustados às peculiaridades de cada agência conveniada, desde que garantido à autuada o direito à ampla defesa e ao contraditório e observados os prazos e as fases do processo, definidos nesta Resolução.

Art. 38. O recurso interposto nos processos de aplicação de penalidades por agências conveniadas obedecerá ao disposto nos artigos 33 e 34 desta Resolução.

Art. 39. As multas aplicadas pelas agências conveniadas observarão a destinação estabelecida no § 10 do art. 13 da Lei $\mathrm{n}^{\circ}$ 10.438, de 2002, e no Anexo de Qualidade dos Contratos de Concessão, devendo ser recolhidas, no primeiro caso, conforme instruções da ANEEL.

Art. 40. Fica revogada a Resolução no 318, de 6 de outubro de 1998.

Art. 41. Esta Resolução entra em vigor na data de sua publicação.

\section{JOSÉ MÁRIO MIRANDA ABDO}

Este texto não substitui o publicado no D.O. de 13.05.2004, seção 1, p. 73, v. 141, n. 91. 